\title{
Excavations at Longbury Bank, Dyfed, and Early Medieval Settlement in South Wales
}

\author{
By EWAN CAMPBELL and ALAN LANE ${ }^{1}$ \\ with contributions by \\ J. Evans, J. Henderson, A. Milles, B. Noodle and A. Rouse
}

LONGBURY BANK, Dyfed is a native British early medieval settlement occupied in the 6th and 7 th centuries A.D. The excavations in 1988-89 produced a series of artefacts which provide evidence of high status: imported Mediterranean pottery; continental pottery and glass; fine metalworking debris; and an unusual Type $G$ penannular brooch. The site is unusual in being undefended and it is suggested that it belongs to a newly recognized class of undefended high status secular sites, other possible examples of which are discussed. The site is placed in its historical and landscape context through the use of pre-Norman and later documentation which appears to show a major shift in settlement in the 8th or gth centuries.

Longbury Bank is a low-lying promontory situated in the parish of Penally, in SE. Pembrokeshire (modern Dyfed), two kilometres E. of the medieval walled town of Tenby and one kilometre NW. of Penally itself (SS I I 999). The site (Fig. I) lies on the estate of the ancient manor house of Trefloyne which lies 500 metres to the W. ${ }^{2}$ In the crags at the N. end of the promontory there is a cave, known as the Little Hoyle or Longbury Bank Cave, which has been a focus for the attention of antiquarians and archaeologists since the mid Igth century because of its Palaeolithic and later prehistoric remains. ${ }^{3}$

As far as the early medieval period is concerned, the site was first recognized in $195^{8}$ by Leslie Alcock, who noted the similarity of some pottery from the I 9 thcentury excavations to the then recently described Classes A and B import wares of Tintagel. ${ }^{4}$ At this time Alcock suggested that the early medieval material might have fallen into the cave from an overlying Early Christian cemetery, but in a later paper noting the discovery of $\mathrm{E}$ ware and another sherd of $\mathrm{B}$ ware in further Palaeolithic excavations he suggested occupation within the cave itself. 5 This latter interpretation has been repeated in most subsequent reviews of the distribution of the import wares. The present authors' interest in the site stemmed from our personal research on settlement sites throughout the Celtic West and North and on research by the 


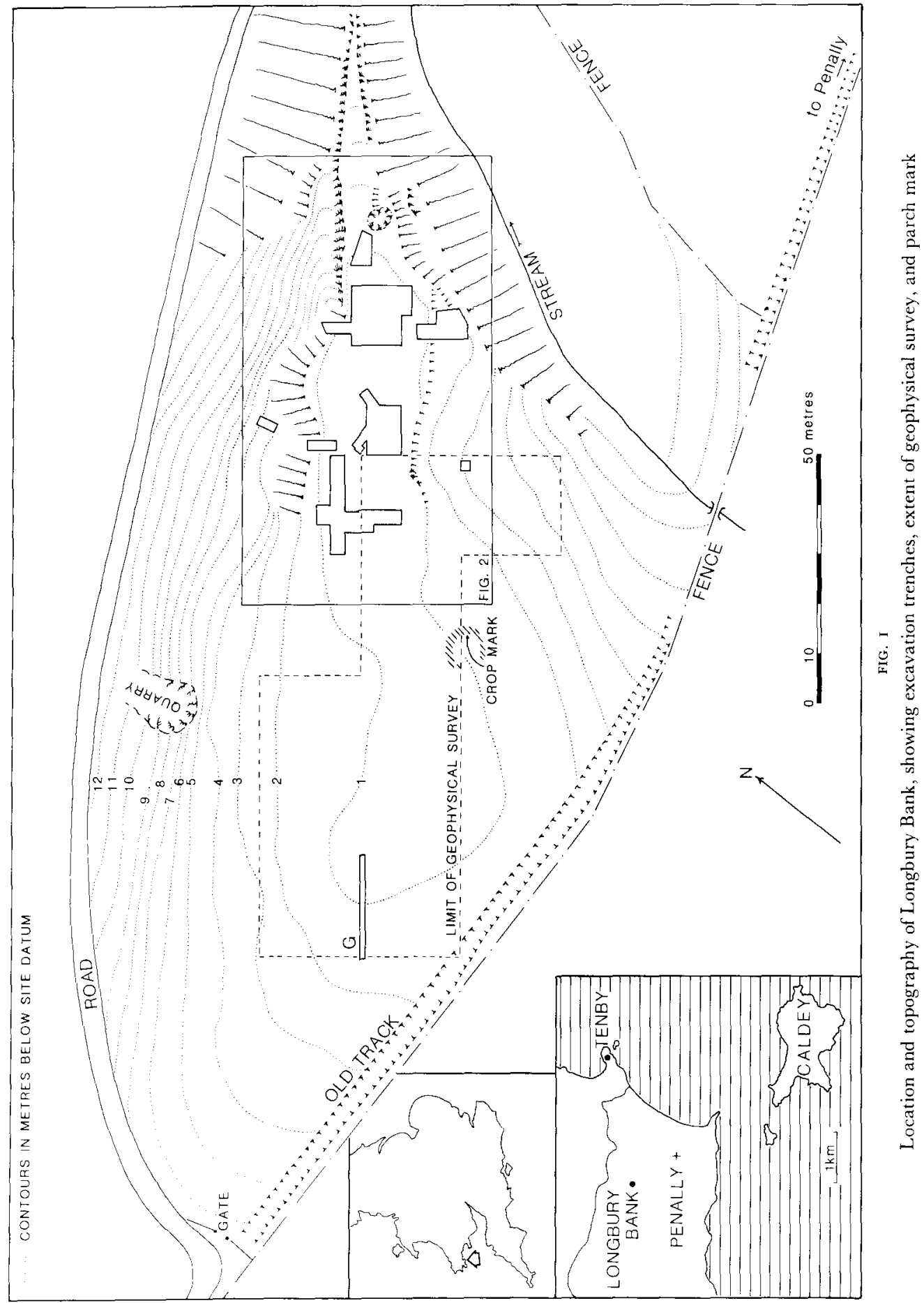


Early Medieval Wales Archaeology Research Group (EMWARG). ${ }^{6}$ At the same time excavations by the National Museum of Wales in and around the cave in 1984 were producing further examples of imported pottery and glass from positions which seemed to preclude early medieval occupation within the cave, and it seemed probable that an important settlement site must have once existed on the ridge above. $^{7}$

Despite the failure of initial remote sensing surveys to identify occupation on the ridge (see below), for a number of reasons the site was selected for trial excavation in I988-89 as a part of a research project by the Department of Archaeology, UWC Cardiff. Firstly, the Penally area was unique in W. Wales in having both extensive post-Conquest documentation and a documented pre-Norman history, since a number of the Llandaff Charters refer to estates in the area. ${ }^{8}$ This presented the possibility of studying the settlement history of the surrounding area, and enabling the date of the origin of the medieval dispersed settlement pattern to be assessed. Secondly, the fact that the site was apparently undefended suggested that excavation might help to resolve the problem posed by the scarcity of early medieval sites in Wales. ${ }^{9}$ Thirdly, by 1984 the site had produced examples of every major class of post-Roman import ware known from western Britain, at that time the only site except for Dinas Powys to have this range of material, suggesting the site was of high status. ${ }^{10}$ The work of one of the authors on the distribution patterns of material on Dark Age high-status sites strongly suggested that such a settlement should lie close to the stray finds from the cave excavations. ${ }^{11}$ Finally, a study of the siting of other similar sites in S. Wales and Somerset showed that these shared a set of topographical characteristics with Longbury Bank, reinforcing the possibility that it was of high status ${ }^{12}$ and making a test of the predictive nature of these characteristics.

Archaeological activity on the site can be divided into four quite distinct periods:

Period o: Palaeolithic and later prehistoric occupation of the cave

Period I: Early Neolithic activity on the ridge and in the cave

Period 2: Early medieval settlement on the ridge in the 6 th and 7 th centuries

Period 3: Agricultural activity on the ridge in the late to post-medieval period

Only the evidence pertaining to Periods 2 and 3 is presented in detail here; Periods o and I will be published separately. ${ }^{13}$ The present report therefore deals with the results of the I988-89 excavations by UWCC, excluding the few Early Neolithic features and finds, but also including catalogues and discussion of all the early medieval material from the igth-century and I958, I984, I986 and I990 excavations around the cave. A full excavation record, including plans, sections and context descriptions, will be deposited in the National Museum of Wales. ${ }^{14}$

\section{SITE SETTING}

The site lies in the rolling farmland of the SE. angle of Pembrokeshire. The underlying geology of the area is a series of Devonian and Carboniferous rocks which are strongly folded, giving a strong E.-W. grain to the topography. Longbury Bank itself is situated on a thick band of Carboniferous Limestone which underlies the 
relatively low-lying ground of the Ritec valley. Immediately to the $\mathrm{S}$. of this valley the site is overlooked by a ridge formed from a harder band of Devonian conglomerates and sandstones, the Ridgeway Conglomerate and the Skrinkle Sandstone. A possible prehistoric trackway, the Ridgeway, runs along the crest of this ridge. To the $\mathrm{N}$. of the Ritec lie shales and sandstones with occasional coal seams belonging to the Millstone Grit and Lower Coal Measures. Iron ore is recorded from fault zones around Penally. ${ }^{15}$

The excavations were sited at the end of a low flat-topped triangular promontory bounded on two sides by low crags which run together to form a rocky arête or spine (Fig. I and Pl. I). Small valleys on either side of the ridge, here referred to as the $\mathrm{N}$. and $\mathrm{S}$. valleys, contain rivulets which run intermittently in dry weather. The promontory overlooks the marshland of the Ritec, a former drowned valley now filled with alluvial deposits which extend into the $\mathrm{N}$. valley. Until as recently as the I 9 th century the Ritec was navigable to within $25^{\circ} \mathrm{m}$ of Longbury Bank, where the Old Quay House was situated, and in former times it was a substantial inlet of the sea. ${ }^{16}$ A series of three dykes across the marsh have led to its gradual reclamation, but the date of all but the most recent, in 1809 , is unknown. ${ }^{17}$ As they are not mentioned by George Owen in his Description of Penbrokshire written in 1603, they are probably of 17 th- or I 8th-century date. ${ }^{18}$ Besanding of the mouth of the Ritec has also taken place, though again the date of this phenomenon is also unknown. Similar besanding has taken place at a variety of periods in S. Dyfed though probably all within the historical past. ${ }^{19}$ It seems certain that the Ritec inlet was navigable, and a sheltered landing place, during the early medieval occupation of the site (see Fig. Io).

The promontory, which rises to 26 metres OD, is riddled with fissures, sink-holes and caves formed by the solution of the limestone. At the NE. end of the ridge there is one substantial cave system, known as the Little Hoyle or Longbury Bank Cave. The cave system runs through the narrow point of the ridge, from the N. cave to the $\mathrm{S}$. cave, with a central sink-hole forming a shaft or chimney to the surface of the field above. Further small entrances and fissures were encountered throughout the excavated areas. Outside the $\mathbf{N}$. cave is a level terrace, the $\mathbf{N}$. platform, where many early medieval artefacts were found during the National Museum of Wales excavations.

The soil profile on Longbury Bank is a rendzina, a thin brown humus resting directly on limestone, but patches of thicker silts and red-brown clays which may be of Late Glacial origin remain in protected areas (see Site F). Although the fields to the $\mathrm{N}$. are arable, Longbury Bank is now pasture, as it was in the mid I gth century. ${ }^{20}$ However the excavations produced evidence of extensive ploughing, datable to the medieval and post-medieval period, which had contributed to soil loss from the top of the ridge with thick colluvial deposits being found on the sides of the ridge (see Site D). Environmental research in the $\mathrm{N}$. and $\mathrm{S}$. valleys revealed colluvial deposits up to two metres thick which were probably connected with the same period of intensification of arable land use. ${ }^{21} \mathrm{~A}$ small series of strip lynchets on the S. face of the S. valley could also belong to this period. The documentary evidence for the date of enclosure is discussed below. 
The finds from the I 984 excavations seemed to provide convincing evidence of an early medieval settlement on the flat top of the ridge and made the site a prime candidate for excavation. Accordingly, a programme of initial survey work was carried out in order to try to locate the extent of any settlement, and at the same time to evaluate the use of remote sensing methods in the discovery of so far unrecognized sites of the period. This work consisted of geophysical surveying, aerial photography, fieldwalking and a detailed topographical survey of the whole of Longbury Bank field.

\section{Fieldwalking}

Although the field is permanently under pasture, in 1987 it was ploughed to improve the grass, and the opportunity was taken to fieldwalk the site. Only a handful of sherds were recovered from the ploughsoil, all of medieval or postmedieval date, despite intensive coverage of the areas later excavated. The lack of early medieval finds is not surprising in view of the excavation of the topsoil in I 988-89. Within the trenches on the top of the ridge the ratio of early medieval sherds to later sherds was around i: 10 . As only five sherds were recovered in the fieldwalking from this end of the field the chances of finding any early medieval sherds were small. The ploughsoil showed no indication of rubble spreads which might have indicated ploughed-out banks or buildings.

\section{Aerial photography}

Available aerial photographs showed only an irregular pattern of light and dark parch marks formed by the numerous limestone solution features whose upper parts excavation showed to contain deeper soil. One more extensive dark area proved to be a thicker deposit of possibly Late Glacial silts and clays (see Site F). During the excavations in I 989 a brief sortie by Terry James of Dyfed Archaeological Trust showed an unusual penannular double-outlined enclosure $c$. Io $\mathrm{m}$ across in the $\mathrm{S}$. of the field (Fig. I and Pl. I). ${ }^{22}$ It was not possible to trench this feature, which may be associated with the Early Neolithic occupation of Period I. There was no sign of buildings or defences anywhere in the field. Given the thinness of the soil, and the fact that bedrock features show as darker patches on the photographs, it can be reasonably assumed that there were no defensive ditches in the unexcavated parts of the field. Local sites of other periods which can be identified on aerial photographs are included in Fig. $\mathbf{I}^{\mathbf{2 3}}$

\section{Geophysical survey}

In $19^{85}$ the National Museum of Wales commissioned a resistivity and magnetometer survey of parts of the field. The results were inconclusive, with no certain archaeological features being identified. ${ }^{24}$ In I 989 a more detailed resistivity survey was carried out by UWCC (Fig. I). This survey was structured to try to locate any possible defensive lines in the unexcavated part of the field after the negative results of excavation on Site $\mathrm{C}$ in I988. Again no archaeological features 
were identified. This was not due to any deficiency in the technique, as it did reveal the line of a small plastic water-pipe trench, not more than $0.3 \mathrm{~m}$ deep in the bedrock, which the farmer had recently laid. The geophysical evidence therefore confirmed the aerial photograph and excavation evidence that there were no defensive features cutting off the promontory and enclosing the early medieval settlement area. Unfortunately the parch mark noted above lay on the edge of the surveyed area and cannot be certainly identified as lying within the area surveyed.

\section{Topographic survey}

The field was surveyed in detail (Fig. I) with the E. part of the promontory gridded and levelled at two-metre intervals (Fig. 2). The top of the ridge is flat, with the $W$. end raised about one metre above the general level. The only breaks in slope occur at Sites $\mathrm{C}$ and $\mathrm{G}$, which were located to check for defensive features. At the $\mathrm{E}$. end of the promontory there is a very flat area where the bedrock is level to within $\pm 0.05 \mathrm{~m}$. This area was excavated (Site E) as it seemed the likeliest location of any large building within the settlement area.

A holloway running along the $\mathrm{S}$. boundary of the field was the original approach to Trefloyne before the construction of the present road through the $\mathrm{N}$. valley in the late igth century. It is perhaps of some significance that this track continues around the hillside directly to Penally and appears to be cut by the Holloway, a medieval roadway. ${ }^{25}$ This suggests that the track linking Trefloyne and Penally, which terminates at Trefloyne, is of considerable antiquity and may be a reflection of the former ownership of the Trefloyne estate by the early medieval monastery of Penally. ${ }^{26}$

\section{Summary}

The failure of the remote sensing techniques to pick up any sign of a settlement is disturbing as it implies that similar sites will only come to light by chance or by the identification of diagnostic stray finds of the period. This has considerable implications for the planning of any large-scale area survey in Wales to identify early medieval settlement. Such surveys are effective in some areas of Anglo-Saxon England because sites can be identified from aerial photographs and from pottery scatters in fields but may not be productive in the absence of those features.

\section{HISTORICAL BACKGROUND}

The area of modern Wales was incorporated in the Roman Empire and remained part of it until the Roman military and bureaucracy was withdrawn or collapsed in the early 5 th century. West Wales, the region of the pre-Roman tribe the Demetae, was never highly Romanized though a major Roman centre at Carmarthen (Moridunum), $37 \mathrm{~km}$ to the E. of Longbury Bank, was occupied till the late 4 th century. ${ }^{27}$ The documentation for the subsequent political history of Wales is poor but Wendy Davies has suggested that kings and kingdoms must have emerged in Wales and in the rest of $W$. and $N$. Britain by the middle of the $5^{\text {th century. }}{ }^{28} \mathrm{~A}$ 
mosaic of fluctuating small kingdoms and sub-kingdoms occupied Wales until the Norman Conquest. Dyfed (later Deheubarth) in W. Wales was one of the few which has a documented existence throughout this period. It has been suggested that the kingdom of Dyfed might have been derived from Irish federate settlement in the late $4^{\text {th }}$ century but given the paucity of reliable documentation this can only be speculation. Nevertheless Gildas refers to Vortipor, a tyrant of Dyfed, in terms which suggest an established kingdom by the date he was writing, conventionally thought to be in the early/mid 6th century. ${ }^{29}$ There seems good reason from place-name evidence, the distribution of ogham memorial stones and later historical sources, to regard this kingdom as being founded, or at least ruled, by an Irish dynasty and Jackson has suggested that it remained Irish-speaking till the 7 th century. ${ }^{30}$ The extent of this kingdom is not historically documented and it is merely an assumption that it would have included the area of Penally and Longbury Bank. West Wales remained part of the kingdom of Dyfed and its successor Deheubarth till the Norman settlement in the late I I th/ early 12 th century. Place-name evidence suggests there may have been significant Scandinavian settlement during the Viking Age but no political unit is documented. ${ }^{31}$ Thus the early medieval settlement evidence from Longbury Bank should be viewed in the context of the end of Roman administration, the creation of the early Welsh kingdoms, the settlement of an Irish dynasty, and the subsequent political history of $W$. Wales including the impact of Vikings and Normans.

\section{THE EXGAVATIONS 32}

The excavation strategy had three main objectives: i) to identify any possible enclosure or defences; ii) to locate buildings; iii) to locate midden deposits. In addition it was thought necessary to test Alcock's hypothesis that a cemetery on the ridge could have accounted for the skeletons in the shaft, even though the topography and depth of soil made this seem unlikely. In 1988 therefore, Trench A was situated near the shaft and immediately above the N. platform where most of the imports had been found in 1984 and I 986 (Fig. 2). Trench $\mathrm{C}$ was situated across the break slope noted previously as a possible location for a defensive line. ${ }^{33}$ Trench $\mathrm{B}$ was located down the side of the ridge on a slight terrace in the hope of finding midden deposits in situ. Trench D was similarly located, though on a steeper slope. Trench $\mathrm{E}$ was selected as the possible site of a major building, following the topographic survey. The 1989 trenches were determined in part by the results of the I 988 excavations. Trench B was extended to encompass the $\mathrm{N}$. end of Structure A. Trench $\mathrm{E}$ was extended $\mathrm{N}$. to find other features which might be linked to the large post-hole found in 1988 . Trench $\mathrm{C}$ was extended $\mathrm{S}$. to investigate what appeared in I 988 to be a palisade trench. Trench $G$ was sited on the break of slope at the $W$. end of the field to confirm the apparent lack of defences (Fig. I). Finally Trench $\mathrm{H}$ was opened and extended to search for other buildings, and to delimit the area of settlement shown by the concentration of imports in Trench E. Trench F was a trial pit dug to investigate the nature of the deposits revealed on the aerial photographs. 


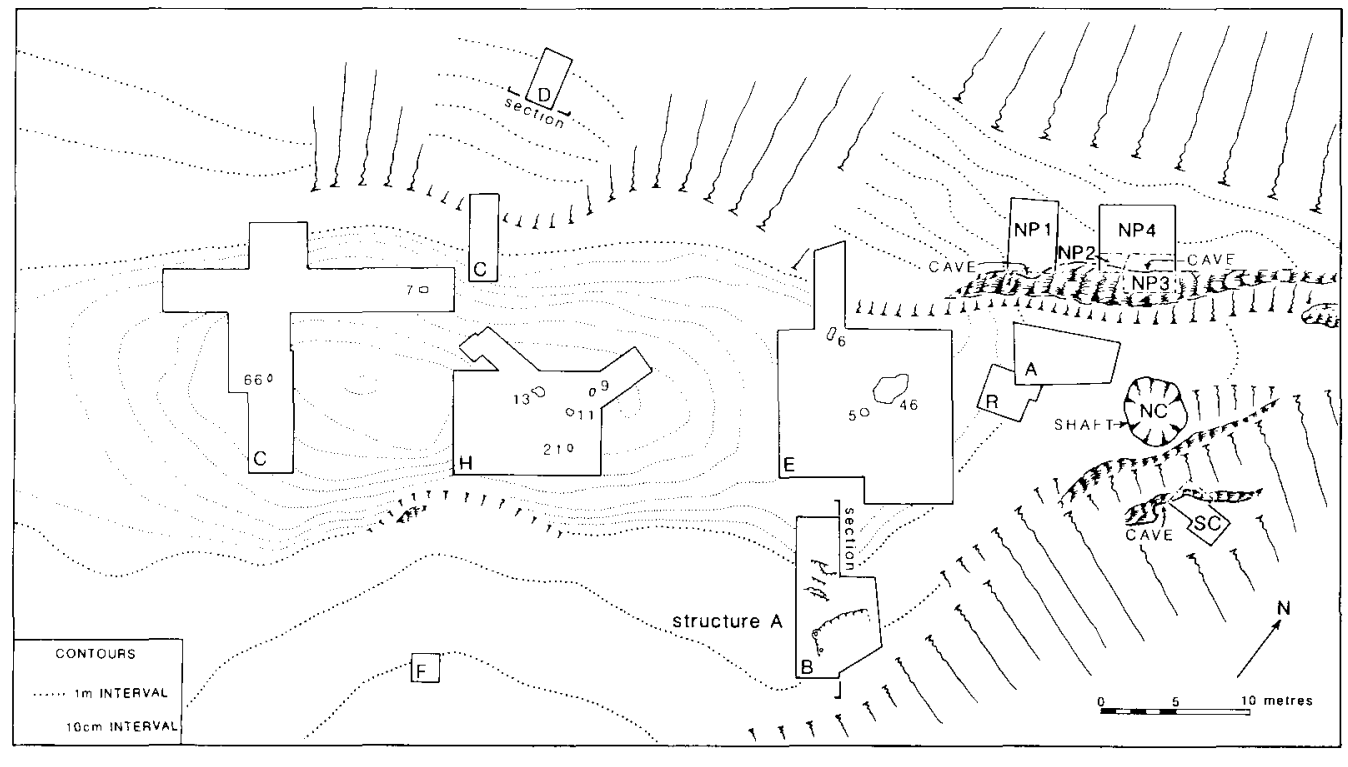

FIG. 2

Excavation trenches, with the main early medieval features numbered, location of sections, and entrances to Little Hoyle cave

This report describes the features found in each trench, context numbers being given in brackets.

As the excavations progressed it rapidly became clear that very little stratigraphy remained on the ridge top and that almost everywhere ploughsoil lay directly on bedrock. Post-medieval sherds were found embedded in the top of the bedrock, and plough furrows scarred the rock surface showing that ploughing had entirely removed and mixed any superficial deposits. Consequently, on most of the site the upper part of the topsoil was removed more rapidly, but still by hand rather than by machine, with the position of all significant finds being recorded. ${ }^{34}$ Comparison of recovery rates showed that only a handful of early medieval finds were likely to have been missed using this method of excavation.

After the removal of the topsoil and cleaning of the bedrock numerous features were revealed, some of which were only visible after a period of weathering. One of the major problems was to separate the many natural solution features in the limestone from the man-made. This problem was compounded in some areas by a combination of rectangular jointing and plough damage which had resulted in the removal of square blocks of bedrock leaving holes which looked artificial. Many of these had a concentration of foreign rocks, mainly sandstone and conglomerate pebbles, in the tops of the features. From the widespread occurrence of this phenomenon it eventually became clear that this was the result of a process of soil migration, with remainée deposits being trapped in the tops of these features as soil was washed through to underground fissures. Another problem was the initial 
difficulty in accepting some bedrock features as solution features, for example the vertical cylindrical pipes in Trenches $\mathrm{C}$ and $\mathrm{B}$ which had smooth vertical sides and were at first sight thought to be artificial. ${ }^{35}$ In some instances such natural features may have been reused as post-holes.

Despite these problems there were rock-cut features which were certainly artificial, with neatly cut edges, and which could be assigned to the early medieval period. ${ }^{36}$ Two Neolithic post- or stake-holes were also identified, but these had very irregular outlines.

TRENCHES A AND R

Trench $A$. No artificial features were located in this area. One feature (2) contained a sherd of continental glass in the fill of a natural shaft. Another (14), a small horizontal gully, produced some prehistoric pottery, animal bone and shell. The only other early medieval finds from the trench were unstratified in the topsoil: two crucible sherds, $L_{1 I^{2}}$ and $L L_{1} 6_{3}$, and a copper alloy droplet, $L B B_{45}$, which indicate fine metalworking in the immediate vicinity.

Trench $R$. This small trench adjoining Trench A was opened in 1984 by the National Museum of Wales to search for evidence of possible open Palaeolithic settlement. No artificial features were recorded. Two abraded sherds of $\mathrm{E}$ ware and one of Bmisc. amphora were recovered from the topsoil.

TRENGH B (Fig. 3)

This ran from the top of the ridge down the S. slope. No sign of any bank or palisade was seen at the break of slope, and there was no rubble downslope which might have indicated a ploughed-out bank. This trench was the only area to preserve some relict stratigraphy. This was due to the angle of slope which had led to the burial of an early medieval building (Structure A) under colluvial deposits on a terrace at the base of the slope. The bedrock of the slope was scarped into a series of rough steps (27) which appeared to lead down towards Structure A.

Structure A consisted of a rock-cut sub-rectangular platform ( I 7 ) with a number of associated post-holes, orientated parallel to the hill-slope. This platform was well preserved on the upslope side, but was progressively degraded by tree root action downslope to the scarp edge. The platform measured $4 \mathrm{~m}$ in length NE./SW. and was at least $2 \mathrm{~m}$ wide. Judging by the slope of the bedrock its original width would have been $3-4 \mathrm{~m}$. The edges were neatly rock-cut, up to a maximum of $0.25 \mathrm{~m}$ deep, producing a fairly level surface for the floor of the structure. In places this surface was worn smooth, suggesting that the floor surface was directly on the bedrock. This supposition is borne out by the finding of large pieces of a smashed Bii amphora, $L B_{3} 80$, lying on the bedrock surface and clearly broken in situ.

Possible post-holes were found around the margins of the platform but they had collapsed into underlying solution fissures (Fig. 4 B). ${ }^{37}$ The best-preserved example (2I), in the NE. angle, had the remains of a substantial carbonized post with an estimated original diameter of $0.15^{-0.20} \mathrm{~m}$ in the fill. This feature had collapsed into an underlying fissure, masking its original edges and its relationship to ( 17 ). A radiocarbon date of cal. A.D. $410-65^{\circ}$ ( 5 I $0 \pm 6$ o в.P.) confirmed its early medieval date. In the middle of the $S$. side of the platform was a circular vertical shaft (I I) of natural origin, though it may have been utilized as a convenient ready-made post-hole. Context (32), though situated in the middle of the N. side, seemed to have been formed by collapse into a fissure and was natural. Context (34), at the NW. angle, was a shallow bowl-shaped hollow which may have supported the base of a post. Context $(36)$, an even shallower feature in the middle of the N. side, is probably natural. Thus, although the ground plan gives an impression of a six-or eight-post structure, only the two corner posts can be regarded as likely locations for roof supports.

The platform was filled with a loose brown soil with limestone fragments ( 15 ) containing a small quantity of animal bone, Bii sherds, a Bi amphora sherd and one small imported 


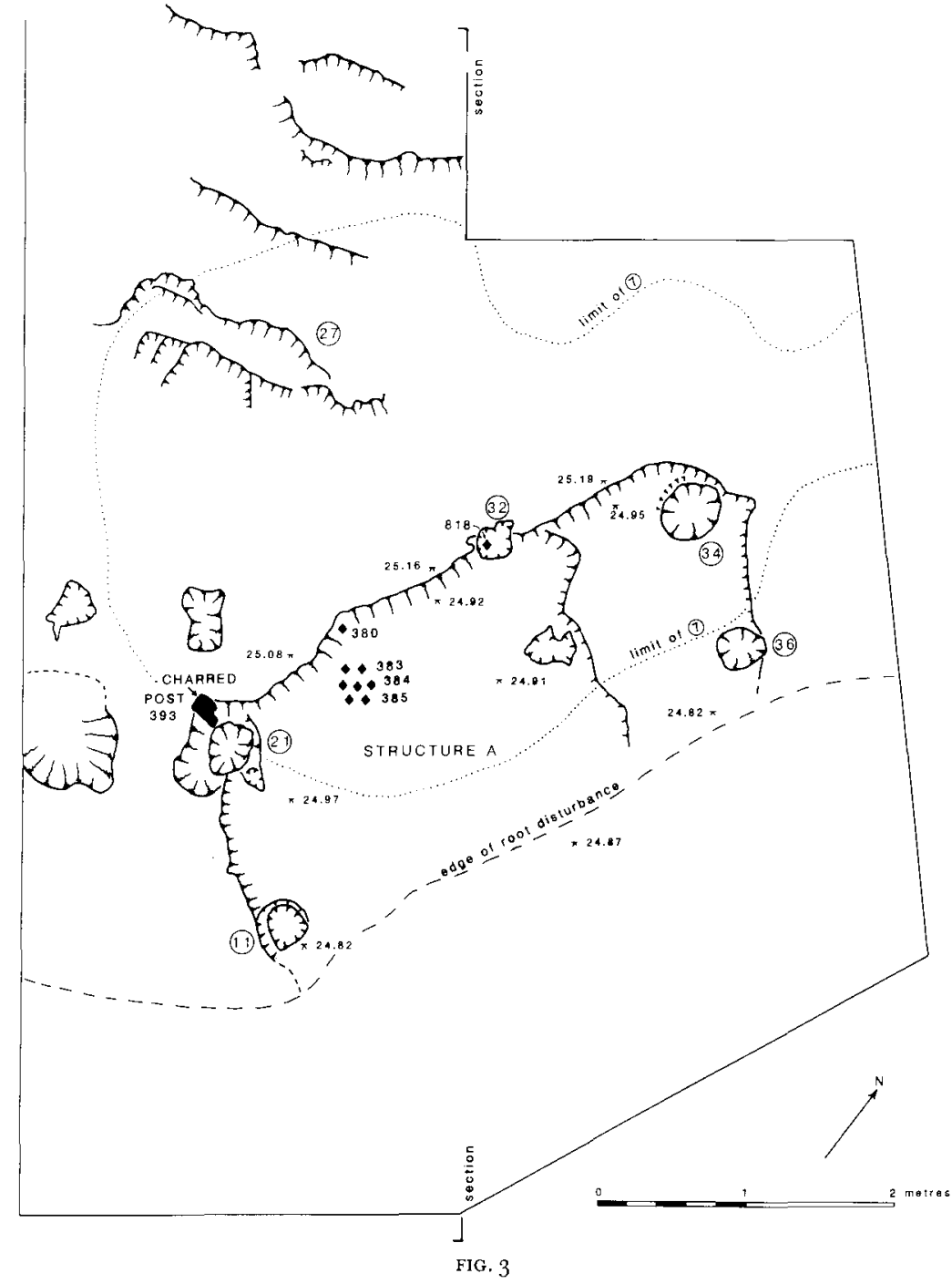

Trench B, showing Structure A with amphora sherds on floor

sherd of glass. Also present was a tiny medieval sherd, presumably a contaminant from root action. This layer was partially sealed by (7), a red-brown friable soil which also sealed the steps (Fig. 4A). This layer was interpreted as colluvium derived from the original red clay $B$ horizon of the upper surface of the ridge, which is almost entirely lost from the soil profile there. Although the upper part of this layer contained modern and post-medieval finds, these were clearly contaminants from the overlying topsoil. The lower part of the layer contained two sherds of imported glass and two medieval glazed sherds, and can be interpreted as colluvium resulting from the intensification of agriculture in the medieval/post-medieval period.

The topsoil contained a large collection of late Victorian pottery and glass, including teacups, a teapot lid, wine glasses and bottles, which were not found elsewhere on the site. 
A
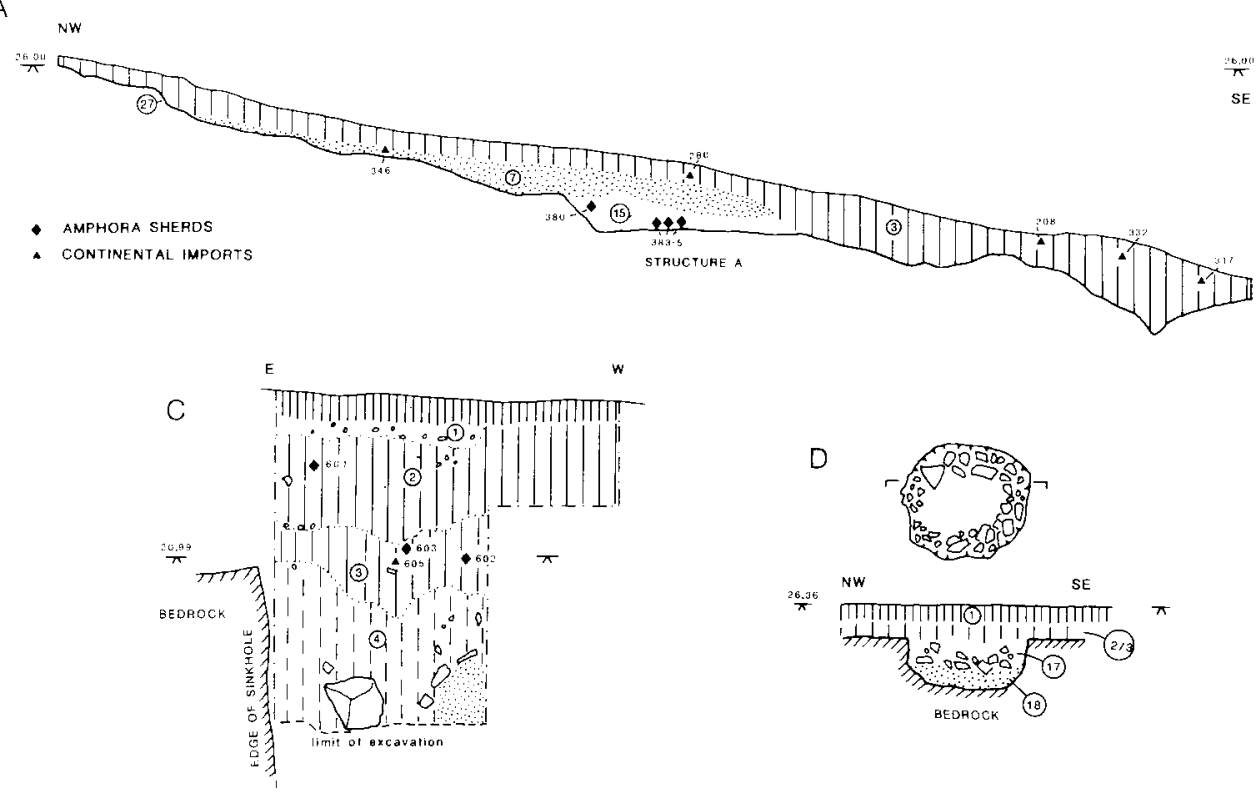

B

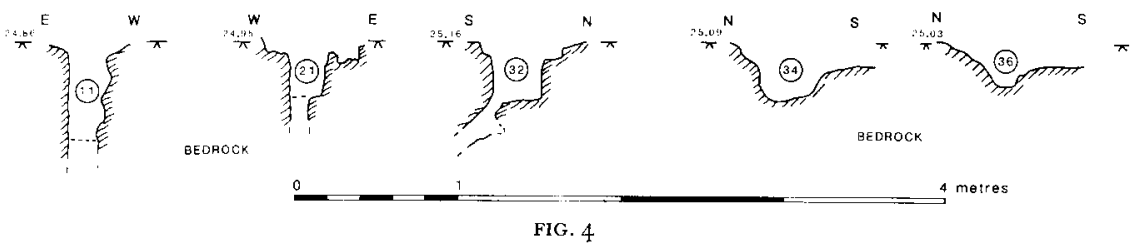

A. Section of Trench B and Structure A. B. Profiles of possible Structure A post-holes. C. Section of Trench D. D. Plan and section of Feature E (5)

This material spread from the top of the ridge down the slope in a coherent group. It seems to represent picnic debris and it can be speculated that it was either the lunch site of the cave excavators of $1877-78,{ }^{38}$ or of visitors to the site. Amongst this debris were two sections of a gold box-link chain, LB233/29I (Pl. II, A). No positive cultural or chronological identification of the chain has been made. Although it could be of early medieval date its spatial association with Victorian material seems on balance to favour a late date of manufacture.

\section{Interpretation of Structure $A$}

As Structure $A$ is the only recognizable building on the site it merits further discussion. Although there are problems in deciding which of the possible post-holes did in fact carry roof supports, the rock-cut platform is clear evidence that a building did exist here. The only reasonably certain post-hole (2I), lies at one corner of the structure, which symmetry suggests may have been a four-post building. As the charred post found in (21) was not very thick, and the post-hole not deep, it is possible that this was a simple lean-to structure with A-frames at the gable ends. There is no evidence for the nature of the walls or roof, but the lack of daub or rubble in the fill of the platform precludes drystone footings or wattle and daub walls. The small chips of limestone in the fill (15) may have been derived from turf, used either as walling or roofing material. There is no indication of an entrance though the wear on the floor is most apparent at the S. end. Why the floor should have been excavated out of the 
bedrock is unclear, as a level surface could have been achieved more easily by dumping soil. The wear on the bedrock showed that no timber or earthen flooring was used. The bedrock may therefore have functioned as a cooling surface and the building as a storehouse rather than living accommodation. This might account for the broken amphora resting on the floor surface.

The size and form of the structure are reminiscent of Anglo-Saxon sunken-floored huts, though given our almost total ignorance of the form of Welsh Dark Age buildings this may not be significant. ${ }^{39}$ Sunken featured buildings were discovered in the $5^{\text {th }}-6$ th century British settlement at Poundbury in Dorset and it may be of relevance that rock-cut floors for small rectangular buildings were recorded at Glastonbury Tor, and there is a rather similar structure at Cadbury Congresbury. ${ }^{40}$ The Longbury Bank structure may therefore not be unusual in a Celtic context.

TRENCH C

This long narrow trench was sited to check for defensive lines, but no indications of any ditches or ploughed-out banks were discovered. ${ }^{41}$ The regularly jointed bedrock in this area of the site made the recognition of rock-cut features difficult. The only certain features in the $W$. end of the trench were a shallow hollow (59) which contained a copper alloy droplet, $L B_{420}$, and a deep post- or stake-hole (66)). Extensions of the trench to the N. and S. did not produce any evidence that either of these formed part of an enclosing fence or palisade. The only other early medieval finds were a few small, very abraded sherds of Phocaean Red Slipware from the topsoil.

At the $N$. end of the trench one certain group of features consisted of a rock-cut rectangular basin (7) which had been backfilled with rubble, hearth-bottom slag and furnace lining. This material was certainly not in situ, nor was there any sign of burning that would indicate metalworking use. A row of three stake-holes $(48)-(50)$ were found to the $S$. of $(7)$, and may have been associated with it. No function can be suggested for these features, but ( 7$)$ presumably belongs to the early medieval phase of activity. A rim and a bodysherd of $E$ ware, $L B_{57}, L B 90$, and a copper alloy strip, $L B_{7}$, were found in the topsoil in this area. The sparse occurrence of early medieval finds shows that this area lay beyond the main focus of occupation. The excavation confirmed the absence of defences.

TRENCH D (Fig. 4C)

This trench was sited on a slight terrace part way down a steep slope, most of which could not be excavated because of the gradient and rock outcrops. It was considered that this terrace might have trapped any midden material thrown over the scarp edge. Excavation revealed a deposit of colluvial hillwash ( $\mathrm{r}$ )-(3) up to I m thick, sealing a deep solution hollow which contained at least another metre of deposits (4)-(6). Near the base of the colluvium a number of early medieval finds were recovered including bodysherds and the handle of a $B i$ amphora, $L B 601-03$, and sherds of $\mathrm{E}$ ware, $L B 60_{5}, L B 6_{14}$. The most interesting find was a piece of scrap silver sheeting, $L B 604$, which appears to have been cut up into a crucible-sized fragment ready for melting down. Other evidence for metalworking in the vicinity took the form of a quantity of hearth slag and vitrified furnace lining.

The thick build-up of colluvium on the scarp slope, overlying the early medieval material, supports the view that there has been substantial loss of soil from the crest of the ridge in the medieval and later periods.

\section{TRENCH E}

This trench exposed $c .140 \mathrm{~m}^{2}$ of bedrock on the flattest area of the ridge which looked the most suitable site for buildings. This area produced the densest concentration of early medieval finds (Fig. I2), but very few features were identifiable.

In the centre of the trench there was a circular rock-cut pit $(5), 0.80 \mathrm{~m}$ in diameter and $0.35 \mathrm{~m}$ deep, which is best interpreted as a post-hole (Fig. $4^{\mathrm{D}}$ ). The remains of what appeared 
to be packing of small limestone chips survived, leaving a post-pipe $0.60 \mathrm{~m}$ in diameter. This feature, like C(7), had been deliberately backfilled to the level of the bedrock with large stones, broken stone objects, hearth bottom slag and other debris (I 7). At the base was a layer of charcoal overlain by less stony soil (I8) which provided a radiocarbon date of cal. A.D. $340-640$ ( $1560 \pm 7$ O B.P.). Amongst the finds used as backfill were: parts of a fired clay loom-weight of 'Saxon' form, $L B_{5} 8_{5} / 704$; part of a saddle quern or rubbing stone, $L B_{553}$; an iron blade, $L B_{540}$; another rubbing stonc, $L B_{596}$; quantities of oyster shell and animal bone; and two almost complete hearth bottoms. Flotation of the fill produced a small quantity of charred grain, including barley, wheat and crop weed species. The heterogeneous collection of material represents a random selection of material which was ready to hand when the hole was backfilled. The nature of the finds suggest that a variety of craft activities including weaving and iron smithing were taking place nearby, as well as the consumption of meat and shellfish and the processing of cereals.

This structural interpretation of $(5)$ presents difficulties; firstly, there is no other similar feature within $6 \mathrm{~m}$ in any direction, making it difficult to see it as part of a building. Moreover, if the layer of charcoal represents the burning of a post in situ the presence of charred plant remains is surprising and the hole is rather shallow for such a large post, even allowing for a substantial loss of topsoil. Despite these reservations, a tentative interpretation as a post-hole seems the only likely function of this feature. ${ }^{42}$

The one other early medieval feature in the trench was a shallow and more irregular rock-cut pit (6), possibly a shallow post-hole, situated on the N. scarp edge. This contained a large amount of animal bone and shell, as well as two sherds of $E$ ware, one of imported glass, an iron nail, $L B 7 O I$, and a copper alloy strip, $L B_{5} 86$. Whatever the original function of this pit, it had been filled with midden material dumped on the edge of the scarp slope, a relict of what were once more extensive midden deposits which would have extended further downslope. The extension of the trench $\mathrm{N}$. led to the recovery of a few early medieval finds, including a copper alloy strap end, $L B_{I I} I_{I}$, and a sherd of decorated glass, $L B_{1 I} 44$, but there was no bone or shell indicative of midden deposits. It is probable that colluvial processes had taken this material further downslope to the N. platform.

Another feature was a large irregular solution hollow (46), which produced a quantity of imported glass. These finds were protected from plough erosion because of subsidence into this hollow, and like the numerous other early medieval artefacts from this trench, are in effect a ghost distribution which reflects the former presence of artefact-rich deposits. Other irregular features (48) (53) (68) and (87), produced odd sherds of imported glass, but these are all certain or probable solution features which have retained topsoil finds in the same manner as $(46)$. There are also a number of small holes in the bedrock which could have resulted from stakes being driven in: (I I) (14) (2 I) (27) (58) (63). These do not form any recognizable pattern and could equally belong to the prehistoric phase of activity. Of the other irregular hollows in the bedrock only (9) gave any appearance of being a possible post-hole.

These bedrock features are not in themselves sufficient to identify Trench $\mathrm{E}$ as the site of an early medieval building. However the distribution of early medieval finds, and the animal bone and shell, do suggest that the major occupation area lay close to this trench. Almost two-thirds of the animal bone and shell from the excavations came from Trench E. In addition, large amounts of midden material, 'black mould with shell and animal bones', were reported to have been found nearby in the shaft of the cave when it was emptied in $1877-78.43$ The distribution of animal bone and shell therefore concentrates on the E. end of the ridge, where there is also the major concentration of early medieval finds (Fig. 12). The distributional evidence is discussed in more detail below.

\section{TRENCHES F AND G}

Trench $F$ was a small test pit located on a terrace with thicker soil deposits. It was hoped to encounter either undisturbed early medieval deposits or possibly Palaeolithic open 
settlement associated with the occupation of the cave. ${ }^{44}$ Beneath the topsoil, which showed no signs of early medieval activity, there was a sequence of almost i $m$ of yellow and grey silts overlying brown and black clays. By analogy the deposits encountered in the cave excavations $^{45}$ these were probably of Late Glacial or earlier fluviatile formation. The lack of any early medieval deposits suggests that the Period 2 occupation was confined to the highest part of the ridge.

Trench $G$ was a slit trench located across the break in slope at the $W$. end of the field to check for the presence of any possible outlying defences across the promontory. No artificial features or early medicval artefacts were found.

TRENCH H

This large trench was located on the highest part of the ridge, between Trenches E and $\mathrm{C}$, in order to delimit the extent of the early medieval occupation. Unlike in Trench $\mathrm{E}$, very few early medieval artefacts were found and there was a complete lack of organic midden material, indicating that this trench lay to the $W$. of the main occupation area. A few rock-cut features were present, mainly in the NE. end of the trench, but the only datable one was a small post-hole $\left(3^{6}\right)$ with Neolithic pottery, flints and a hammerstone.

A number of other features which appear to be post-holes, or the basal parts of post-holes, include (9) (I I) (I3) (2 I) and (23), which are $0 . \mathrm{I}-0.3 \mathrm{~m}$ deep. These are rock-cut but only (I I) has possible packing, and that may be secondary. These pits do not form any coherent pattern, nor are they datable, though their neatly cut edges resemble those of the carly medieval features in Trench $\mathrm{E}$, and it is assumed they are of early medieval date. During excavation features (9) (I I) and (I3) looked as if they might form the corner of a structure and accordingly the trench was extended to the $\mathrm{N}$. and W.; however, only the one Neolithic post-hole was found. It is possible that some of these features form part of a structure mainly located to the NW. of the trench, but they are so shallow that they must represent post-bases rather than post-holes and the chances of recovering a building plan are small due to the plough damage.

\section{SUMMARY OF THE EXCAVATIONS}

The results of the excavations, particularly in Trenches C and G, combined with the aerial photograph and geophysical survey, show that the site was not defended by banks and ditches and that there was no trace of a palisade enclosure. Despite the lack of defences there was indisputable evidence that Longbury Bank was an important settlement site in the early Middle Ages. A class of undefended settlement of the period has thus been recognized, and may point to the existence of other settlements at sites which have produced stray finds of imported pottery and glass or metalwork of the period.

The structural evidence from the excavation is disappointing due to the removal of almost all the post-Glacial deposits by later ploughing. Rock-cut features were found scattered over the summit of the ridge in the area covered by Trenches $\mathrm{C}$, $\mathrm{E}$ and $\mathrm{H}$, but no coherent structures could be recognized. These features have been interpreted mainly as post-holes although none is very deep. It seems likely that these rock-cut features are merely the bases of holes dug through a considerable burden of topsoil and therefore that the lack of building plans might be due to some of the post-holes not reaching the bedrock. The nature of any major buildings can only be inferred. The lack of rubble on the site precludes the existence of stone-built structures. As for post-built wooden buildings, the putative post-holes might be 
regarded as too shallow to have supported any substantial building, but they are as deep as those at South Cadbury, which Alcock interpreted as belonging to a large Dark Age timber hall. ${ }^{46}$ Some type of sill-beam or post and sill-beam construction seems to be the most probable explanation for the shallow sub-surface features. Unfortunately most of the evidence for such buildings would have been destroyed by plough action.

Only part of the small ancillary Structure A in Trench B survives, protected by the accumulation of hillwash on a slight terrace. It might be a storehouse, approached from the main occupation area by a series of steps. The form of the building may be a local functional response to the problem of keeping food stores cool.

It is the finds from the site which are of considerable importance. The distribution of the early medieval artefacts, though mostly from the topsoil, can be regarded as giving an indication of the original discard pattern as ploughing does not appear to move finds laterally by any great extent. ${ }^{47}$ Erosion may have removed more from the edges of the hill but not in such a way as to distort the remnant distributions. The distribution of early medieval imports shows a concentration on the NE. end of the ridge, in Trench $\mathrm{E}$ and on the N. platform (Fig. I 2A, B). This area coincides with the areas where organic midden material has been found, suggesting that most of the midden debris was disposed of over the $\mathrm{N}$. cliff edge or into the cave shaft, or else allowed to accumulate in the E. part of Trench E. These areas are conveniently downwind of the main occupation area. This concentration of finds is more marked when the size of sherds is taken into account. The evidence for fine metalworking is dispersed, being found on Trenches $\mathrm{A}, \mathrm{C}$ and $\mathrm{D}$ as well as $\mathrm{E}$ and the N. platform (Fig. I $2 \mathrm{C}$ ). This suggests that these craft activities were carried on in the more peripheral areas of the site, though still close to the main living areas. These distributions enable a tentative interpretation of activity areas to be put forward, the general pattern of which conforms to that at Dinas Powys. ${ }^{48}$ Indeed the distribution of imports within the area of occupation is broadly comparable between the two sites if one leaves out the Dinas Powys midden deposits (Fig. I I). The similarity between the two sites will be further discussed below.

\section{THE FINDS}

By E. CAMPBELL (unless otherwise stated)

The discussion of the finds concentrates on the known early medieval artefacts, but it should be noted that, due to the lack of vertical stratigraphy, there are many undiagnostic finds in the Period 3 ploughsoil which might belong to Period 2. Full catalogues are given in the archive report.

The finds are identified by a finds number in italics. These are codified with a set of initial letters which distinguish the various campaigns of excavation: $L B$ for the I988-89 excavations by UWCC on the ridge; $L H$ for the ${ }_{195}^{8-59}$ season by McBurney on the N. platform outside the caves; $N C$ for the I $877-78$ diggings within the cave; and $N P, R, S C$ or $S V$ for the I $984-90$ National Museum of Wales excavations, $N P$ on the N. platform, $R$ on the ridge, $S C$ in the $\mathrm{S}$. cave and $S V$ in the valley to the south. After the description of each object the dimensions, year of excavation, trench code (see Figs. I and 2), with grid square location 
in NPI, and context in brackets are given. An asterisk denotes illustrated examples; L.: length; W.: width; T.: thickness; D.: diameter; Max. S.: maximum chord size of sherd. The finds are all deposited in the National Museum of Wales, except for the $1877-78$ finds which are in Tenby Museum.

\section{GOLD}

The only object of gold $(L B 233 / 29 I)$ is a box-link chain (Pl. II, A) which has not been positively identified, but is of a very pure gold (Table IA). A range of dates from the $5^{\text {th }}$ century to the igth century and origins from Byzantium to West Africa have all been tentatively made. If the chain is of early medieval date it would be of considerable importance, but as it was found in a concentration of Victorian artefacts it may be a loss of that period. 49

$L B 233^{-29 I^{*}} \quad$ Gold box-link chain in two pieces. $L B_{233}$ is $92 \mathrm{~mm}$ long with 99 links; LB29I is $75 \mathrm{~mm}$ long with 79 links. Each link is sub-rectangular, made from a thin strip about $1 \mathrm{~mm}$ wide, linked at right angles to the preceding link. The links are handmade, not machined. The method of fixing is not visible, but electron microphotographs show there is a minute raised boss in the centre of one face of each link, possibly a solder spot. Weight 2.043 g. I 988 LB233: B (2); LB29I: B (4).

SILVER

The single piece of silver (LB604) from the site, an off-cut of sheet silver (Fig. 5), is almost certainly of early medieval date in view of its stratigraphic position, sealed by one metre of hillwash and at the same level as imported pottery.

$L B 604^{*} \quad$ Silver off-cut. Trapezoidal plate, two edges at right angles are original smoothed edges. The other long edge is raggedly cut and the other short edge has been bent and broken. No sign of polishing or turning marks. The surface is scored and scratched but the metal is in excellent condition. An off-cut from a rectangular plate probably intended for melting down. I $7 \times 10-12 \mathrm{~mm}$, T. I mm. i $988 \mathrm{D}(3)$.

This piece was presumably cut up for melting down, like the scrap bronze from the site. The piece has been cut from a large sheet of some kind, but there are no indications from turning or polishing marks that this was a vessel. The only contemporary large silver objects found in NW. Europe were vessels of Byzantine origin, exemplified by the bowls and plates in the Sutton Hoo treasure. ${ }^{50}$ Analysis of the silver composition shows that it was a very pure silver $(96 \%)$, with only a small percentage of copper $(2.3 \%)$ as a minor element (Table IA). These values are very similar to those of the Sutton Hoo vessels, though these vessels also had small amounts of lead and gold, which are usually present in silver of this period in small amounts, ${ }^{51}$ while these elements were only detected at the trace level $(<0.01 \%)$ in the Longbury Bank sample. It is possible that the difference may be due to the different analytical technique used. However there is no proof that the piece was cut from a contemporary object, and it is equally possible that it came from a reused Roman period vessel, which have similar silver compositions to later Byzantine ones. ${ }^{52}$ If it were a genuine Byzantine import of 6th-century date it would be the first such vessel known to have reached the Celtic West.

COPPER ALLOY

Few copper alloy artefacts were recovered, and all are from the topsoil except $L B_{5} 86$ and $L B_{420}$. Nevertheless many of the pieces can be confidently assigned to the early medieval period on the basis of comparison with material from Dinas Powys.

$L B 7 \quad$ Sub-rectangular strip, one end rounded, the other broken. ?Part of strap end or billet. io $\times_{4} \times$ I mm. $1988 \mathrm{C}(\mathrm{I})$.

$L B_{145} \quad$ Large bronze droplet of irregular shape. Analysis showed a high tin bronze (Table I A). $22 \times 13 \times 5 \mathrm{~mm}$. $1988 \mathrm{~A}(\mathrm{I})$. 

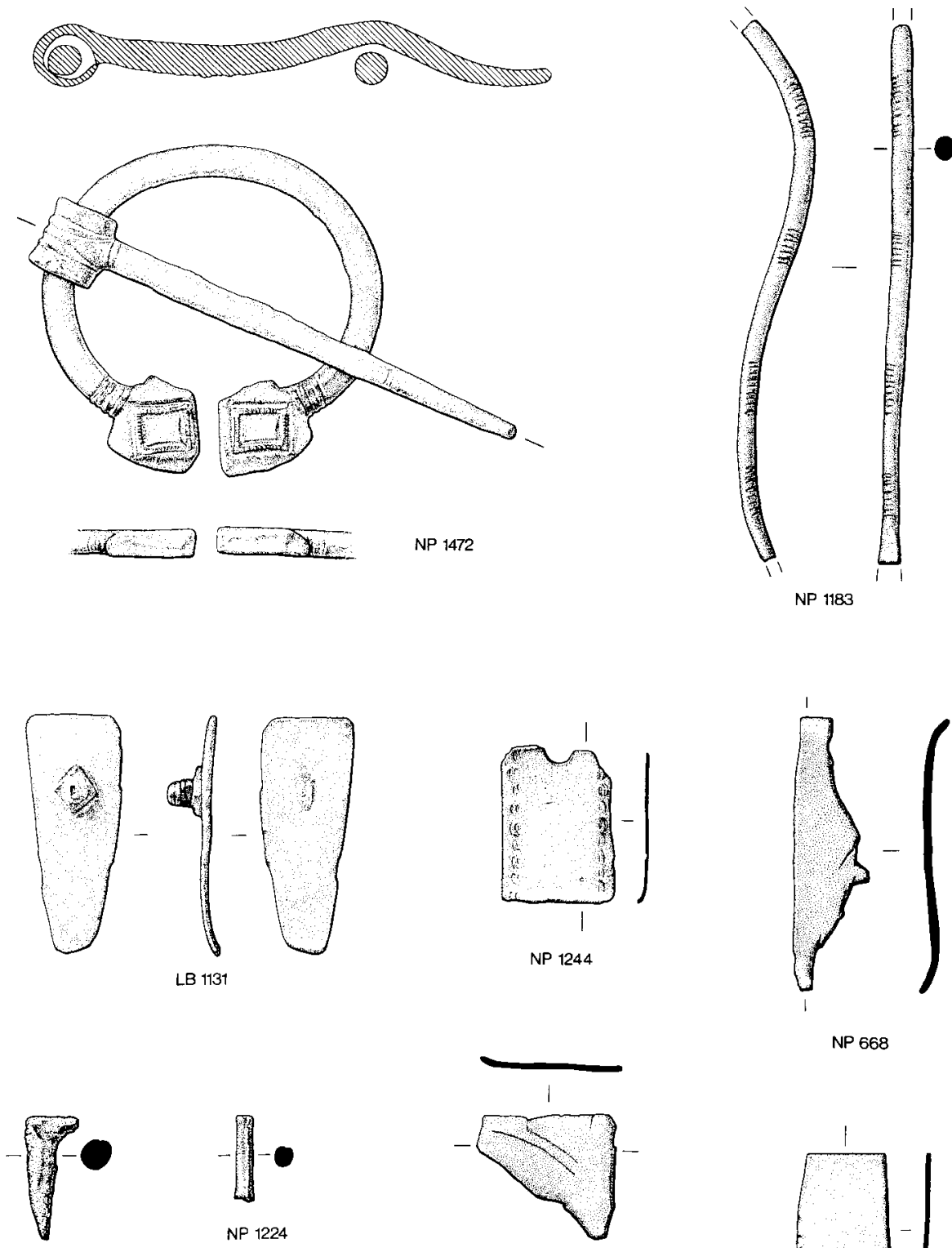

NP 1358

NP 1224

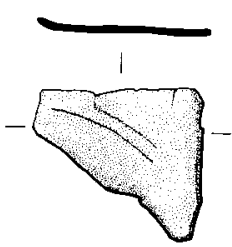

NP 480

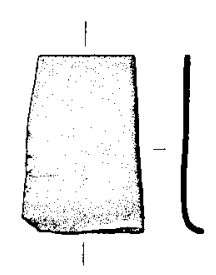

LB 604

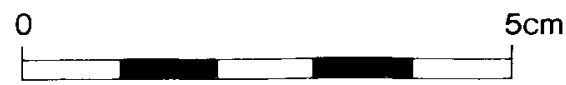

FIG. 5

Non-ferrous metalwork. Copper alloy: Type G penannular brooch, $N P_{1472}$; bracelet? $N P_{11} 83$; belt fitting? $L B_{113}$; belt fitting, $N P_{1244}$; offcut, $N P 668$; rivets, $N P_{135}{ }^{8}, N P_{1224}$; offcut, $N P_{4} 80$. Silver: offcut, $L B 604$ - Scale r: 1 
Tiny rounded bronze droplet. Analysis showed high tin bronze (Table IA). $7 \times 4 \times 3 \mathrm{~mm} .1988 \mathrm{C}(58)$.

$L B_{453} \quad$ Unidentifiable fragment, badly corroded. $5 \times 5 \times 1.5 \mathrm{~mm}$. I $988 \mathrm{C}(72)$.

$L B_{5} 86$

Copper alloy strip, spatulate shape, broken at one end. Corroded. Signs of bending at break. ?Off-cut. $22 \times{ }_{2-4} \mathrm{~mm}$, T. $0.5 \mathrm{~mm}$. $1988 \mathrm{E}(26)$.

$L B_{1131^{*}} \quad$ Triangular plate, apex rounded. Rivet or stud of iron with square washer and a series of five round ?spacers on rear face. One edge decaying, otherwise in good condition. ?Strap end. $30 \times 12 \times 1 \mathrm{~mm}$, Rivet L. $4 \mathrm{~mm}$. $1989 \mathrm{E}(76)$.

$N P_{4} 80^{*}$

NP668*

Triangular corner of rectangular sheet, cut crudely across with chisel. Two parallel cuts on surface. One end bent and broken. Scrap off-cut. Patinated. I $5 \times 17 \times 0.5 \mathrm{~mm}$. I $986 \mathrm{NP}_{4}$.J9 (3/13).

$N P_{11} 8_{3}^{*}$
$N P_{1224^{*}}$
$N P_{1244^{*}}$

Fragment of sheet. One long edge straight and original, the other crudely cut with chisel. Both short ends broken by bending over. Patinated. Scrap off-cut. $33 \times 8 \times 0.6 \mathrm{~mm}$. $1986 \mathrm{NP}_{4}(3 / 13)$.

Thick wire bent into S-shape. Circular section, with one end flattened on both sides as if hammered, but broken at this point by bending. The other end is also broken. Decorated on one side with four groups of transverse incisions, $7-1$ i in each group, apparently chisel-cut. Good patina. ?Bracelet, cut up for scrap. Unlikely to have been a pin or brooch. L. $68 \mathrm{~mm}$, D. $2 \mathrm{~mm}$. I 990 NPI.CI $(\mathrm{I})$.

NPI224* Rolled tube of copper alloy. One end complete, folded over with slight lip, the other end missing. Rivet pulled off plate. L. ro mm, D. 2 mm. NPI.G. (I).

$N P_{1244^{*}} \quad$ Rectangular plate, broken at both ends by bending, with part of circular rivet hole. Stamped decoration along long edges, rows of cresent moon shapes formed by two stamped arcs. Belt-fitting broken up for scrap. Rivet $N P_{1358}$ may belong to it. $20 \times \mathrm{I}_{4} \times 0.5 \mathrm{~mm}$. Hole D. $3 \mathrm{~mm}$. $1990 \mathrm{NP}_{\mathrm{I}}$.F2 ( I).

NPI358* Tube of rolled sheeting, one end folded over to form rivet head. Circular shaft tapering to a point. Head sub-square, incomplete. Badly corroded. Possibly part of NPI244. L. I $4 \mathrm{~mm}$, D. I-3 mm. I 990 NPI.F $4(2)$.

$N P_{1472^{*}} \quad$ Penannular brooch, complete except for tip of pin. Brooch cast, fine details suggesting a wax model was used. Hoop of oval form with circular section, undecorated except at terminal junctions where there are five grooves extending three-quarters of the way round the hoop in a band $4 \mathrm{~mm}$ wide. The terminals are large and expanded, square-ended irregular pentagons in outline. They are flat-backed, $3 \mathrm{~mm}$ thick, with three corners of each chamfered to leave the upper face with a rectangular field, $7 \times 6 \mathrm{~mm}$. These central fields are decorated with an incised rectangle outlined by a double border which is beaded with incised lines. The pin is also cast, with the top hammered over around the hoop. The pinhead is barrel-shaped with four incised longitudinal grooves which do not extend to the rear face. Another two transverse grooves separate the head from the shaft. The shaft is circular in section, tapering gradually from $4 \mathrm{~mm}$ to $2 \mathrm{~mm}$ in diameter towards the point. The shaft is characteristically bent in profile where it crosses the hoop with a further two transverse grooves below the bent part, and a faint longitudinal groove above this. The surface of the terminals is worn, removing some of the beading. The copper alloy has a blackish patina and patches of lumpy metallic silver can be seen on the pin. Hoop W. $42 \mathrm{~mm}$, section D. $4 \mathrm{~mm}$; pin L. $63 \mathrm{~mm}$; pinhead W. $9 \mathrm{~mm}$. D. 7 mm. I 990 NP I.G $4 \mathrm{sw}(2)$.

\section{DISCLSSION OF THE NON-FERROUS METALWORK}

The most important piece is the penannular brooch (NPI472) belonging to Fowler's Type G, which have faceted terminals. This brooch (Fig. 5 and Pl. II, B) differs from other known examples in that the terminal decoration consists of an incised rectangle with a ribbed border. This type of decoration is clearly related to the sunken lozenges found on what Dickinson has classified as Type $\mathrm{G}_{3}$ brooches. ${ }^{53}$ The typology and chronology of the Type $\mathrm{G}_{2-4}$ brooches, which are generally considered to be later than the Type $\mathrm{G}_{\text {I }}$ of the 5 th to 6 th centuries, is in need of serious revision. ${ }^{54}$ Large numbers of moulds for ' $\mathrm{G}_{3}$ ' brooches have been recovered from 7 th-century contexts at the Scottish royal site of Dunadd, and other 
similar moulds show manufacture in Ireland. ${ }^{55}$ In $N P_{1472}$ the length of the pin in relation to the hoop diameter (1.5:I), the large size, the well-formed shape of the terminals and the decoration all indicate that this brooch is of a later date than the Type $G_{i}$ brooches. The form of the pin is similar to the barrel-headed pins found on developed Irish zoomorphic brooches of the 6 th to 7 th centuries, and the pinhead is very similar to that on the Pant-y-Saer brooch from Anglesey which is probably of the same date. ${ }^{56}$ It seems likely that a variety of regional forms of later Type $\mathrm{G}$ brooches developed from the ancestral 'Type $\mathrm{G}_{1}$ and that $N P_{1472}$ belongs to a distinctive native British tradition of metalwork which evolved in Wales. $\Lambda$ number of recent finds of metalwork in SE. Wales suggest that the use of stamped decoration

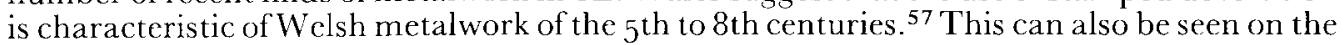
lost Kenfig brooch, and on one of the two other Type $\mathrm{G}$ brooches from Pembrokeshire, that from Linncy Burrows (Fig. I3). ${ }^{58}$ This latter brooch is of great interest as it appears to be a crudely made copy of NPI 472 or a very similar brooch (PI. II, c). Rather than being cast, both the hoop and the pin of the Linney Burrows brooch are each hammered from a bar of copper alloy. The decoration is crudely formed by chisel stamping the cold metal, but the elements of

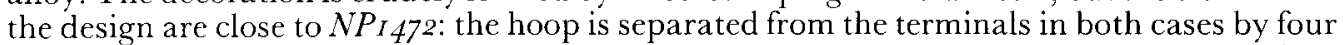
or five grooves; the pinhead decoration on both consists of transverse and longitudinal grooves; and the rectangular pattern on the Linney Burrows terminals is clearly intended to represent the more sophisticated decoration on the Longbury Bank terminals. The two brooches are likely therefore to be contemporary, and the presence of both in the same area of Pembrokeshire suggests that they were manufactured locally. Significantly the Linney Burrows brooch comes from an area of sand dunes which has also produced $E$ ware (Fig. 6, A) and a Dark Age bone comb from sand-blows. ${ }^{59}$ The same locality also produced another stamped copper alloy object probably of the same date. ${ }^{60}$

The date of these brooches is difficult to ascertain given the lack of stratified comparative material. It has been pointed out that all the evidence suggests that Type $\mathrm{G}_{2}-4$ groups post-date the Type $G_{1}$ of the $5^{\text {th }}$ or 6 th centuries. However the evidence of the Trewhiddle silver Type $G$ brooch has been taken to indicate that some Type $G$ brooches continued to be produced possibly as late as the 9 th century. ${ }^{61}$ The evidence of moulds from the Mote of Mark and Dunadd in Scotland, and Moynagh Lough in Ireland, shows conclusively that late Type $\mathrm{G}$ brooches were being manufactured in these areas in the 7 th and early 8 th centuries. ${ }^{62}$ The two Pembrokeshire brooches have a quite different decorative scheme which is not matched elsewhere, apart from an even more crudely formed example from Port-y-Candas on the Isle of Man, which has irregular chisel cuts on one terminal and a crude rectangle on the other. ${ }^{63}$ This brooch would probably not have been recognized as being related to Type $G$ without the example of the Linney Burrows brooch. It was found in close association with the base of an $\mathrm{E}_{2}$ beaker, again indicating a 7 th-century date. ${ }^{64} \mathrm{~A}$ similar date would seem reasonable for the Pembrokeshire brooches, both in terms of their typology and their association with imported pottery of the 6 th and 7 th century. The beaded border on the Longbury Bank terminals is unique and may well be an attempt to imitate filigree decoration. This in itself would indicate that the brooch did not date before the 7 th century when Celtic artisans began to copy Anglo-Saxon filigree techniques of decoration. ${ }^{65}$ The use of silvering on the brooch is also unique, and contrasts with the more normal tinning of the period. In this context another recently discovered Welsh brooch, an elaborately decorated silver gilt penannular from Newton Moor, Mid Glamorgan, is of interest. ${ }^{66}$ This has large terminals of similar shape to Type $\mathrm{G}$ brooches, with a sunken lozenge infilled with crudely beaded gold filigree decoration. This unique brooch must be of 8 th- or 9 th-century date, but illustrates that filigrec was being used in Wales on brooches evolved from late Type G brooches. In summary then the Longbury Bank brooch would appear to be 7 th-century in date, and possibly later rather than earlier in that century, or even 8th-century.

Finally, in the wider context, it should be noted that there is yet another recently discovered Type G brooch from Pembrokeshire, an enamelled example from a redeposited context at Goodwick (Fig. I 3) ${ }^{67}$ This brooch is unique amongst Type G brooches in having well-preserved enamel in the sunken lozenge. Although it belongs to the $\mathrm{G}_{3}$ group it has 
decorative elements on the terminals which relate it to the enamelled zoomorphic brooches of the 'developed' phase, dated by Graham-Campbell to the 6th and 7th centuries. ${ }^{68}$ If the Goodwick brooch was manufactured in N. Pembrokeshire this would indicate small-scale regional differences in contemporary Type G brooches. It may therefore be significant that this difference corresponds to the division between areas of Irish and native settlement shown by the distribution of place-names and ogham inscriptions (see discussion below and Fig. 13).

The other copper alloy objects are less distinctive but are still of interest in view of the paucity of metalwork of this date in Wales. $L B_{12} 44$ is a plate from a belt-fitting (Fig. 5 ) of a type found in Anglo-Saxon contexts. There are two similar plates from Dinas Powys, though the stamped decoration is different, which Graham-Campbell dates to the 6th to 7 th centuries. ${ }^{69}$ This piece may therefore be an import, though exactly similar stamped ornament is found on a newly discovered brooch from Herefordshire which is probably of British manufacture. ${ }^{70}$ The triangular strap-end, $L B_{113 I}$, is less distinctive, though also possibly Germanic, but has unusual washers on the rivet (Fig. 5).

Scrap material, cut up for melting down, includes a number of irregular pieces, $N P 480$ and $N P 668$, a possible billet, $L B_{7}$, a strip, $L B_{5} 86$, and a thick piece of twisted wire, $N P_{I I} 8_{3}$. This last piece (Fig. 5) is decorated on one side with groups of grooves and may originally have been a bracelet as one end starts to expand as if to form a hook-and-eye fastening. Although simple wire bracelets are common in both Late Roman and Anglo-Saxon contexts it is difficult to find an exact parallel for this piece. The groups of grooving seem to relate it to Late Roman types, but these usually have rectangular or D-shaped cross-sections. ${ }^{71}$ Anglo-Saxon examples are often of circular wire, but are usually undecorated. It is possible that this could be a native British type descended from Late Roman prototypes. Further signs of the melting down of scrap or the primary production of bronze are given by the two molten droplets, $L B_{145}$ and $L B_{42} 2$.

\section{Non-ferrous metalworking}

Fine metalworking is represented by crucible and heating tray fragments, scrap bronze and silver, metal droplets and a possible billet. The number of finds is very small compared to sites such as Dinas Powys, but given the localized distribution of metalworking deposits on early medieval sites, this may be due to chance factors of survival and discovery. No mould fragments were identified, but only a few mould fragments were found at Dinas Powys and Tintagel. ${ }^{72}$ The scrap copper alloy and silver comes partly from cut-up sheets, and partly from broken-up belt and other fittings, again as at Dinas Powys. ${ }^{73}$ The Longbury Bank material may have been either brought to the site as fittings in use, or as scrap. ${ }^{74}$

TABLE I

NON-FERROUS METALWORK ANALYSES ${ }^{75}$

\begin{tabular}{|c|c|c|c|c|c|c|c|c|c|c|}
\hline \multicolumn{11}{|c|}{ A. Atomic Absorption Spectroscopy } \\
\hline No. & Type & $\mathrm{Gu}$ & $\mathrm{Sn}$ & $\mathrm{Zn}$ & $\mathrm{Pb}$ & $\mathrm{Ag}$ & $\mathrm{Au}$ & $\mathrm{Ni}$ & $\mathrm{Fe}$ & Total \\
\hline$L B_{I 45}$ & droplet & 86.29 & I 2.50 & nd & $0.7 \mathrm{I}$ & $\operatorname{Tr}$ & na & nd & nd & 99.50 \\
\hline$L B 233$ & gold chain & I. 40 & $\operatorname{Tr}$ & nd & $\mathrm{Tr}_{\mathrm{r}}$ & I. I 3 & 95.80 & nd & na & 98.33 \\
\hline$L B_{420}$ & droplet & $88.3 I$ & I 0.65 & 0.15 & 0.80 & $\mathrm{Tr}$ & na & nd & nd & 99.91 \\
\hline $\mathrm{CB}_{604}$ & silver scrap & 2.30 & $\operatorname{Tr}$ & nd & $\operatorname{Tr}$ & 96.03 & $\Gamma_{\mathrm{r}}$ & nd & $\mathrm{na}$ & 98.33 \\
\hline
\end{tabular}

B. Electron Probe Microanalysis

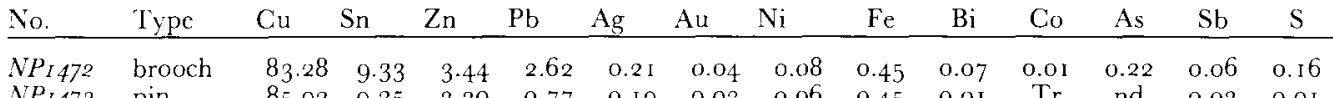

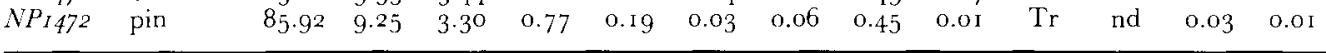


The analyses of the bronze metal droplets provides direct evidence of the type of copper alloys being used on the site to produce fine metalwork. Both analyses show a pure high tin bronze with little or no zinc or lead. This type of composition, lacking in zinc but with or without lead, is characteristic of other metalworking sites in the west, such as Dunadd, and of other early medicval metalwork from Wales. ${ }^{76}$ These pure bronze compositions probably reflect the availability of purc copper and tin ingots in the Celtic West and are rather different from the ternary or quaternary alloys found in Anglo-Saxon metalwork which tend to contain zinc, being derived from Roman scrap. ${ }^{77}$ Further analysis of apparently scrap Anglo-Saxon fittings found on British sites should be able to determine whether these are indeed of Anglo-Saxon origin or are of local manufacture. The Type $\mathrm{G}$ brooch analysis is therefore unusual in containing a small amount of zinc. This may reflect the rather later date suggested for this piece, when these divisions in alloy type were breaking down, or may be due to a use of Germanic scrap such as the belt fittings (e.g.NPI244) from the site. The close similarity in the results of many of the elements in the pin and brooch hoop show that they were probably cast from the same melt, but with lead being added to the melt to improve the casting qualities for the brooch hoop. Lead in the pin would be undesirable as it had to be bent round the hoop, and lead increases brittleness. This lack of lead in items which were intended to be wrought is also found in other Celtic analyses mentioned above.

IRON

Only one iron object, $L B 540 / 54^{2}$ (Fig. 8), definitely came from an early medieval context. This is a flat tapering blade with a perforation at one end which is of unknown function, though the shape suggests it is possible that it is from a balance arm. Three identical studs with large heads and short square shafts (e.g. $L B_{73} 8$ ) (Fig. 8) were found in Trench E. Their distribution, which is similar to that of the imported pottery and glass, suggests an early medieval date. ${ }^{78}$ Another possible example, $L B 70 I$, probably came from the early medieval feature context E (6). These may be from domestic fittings, possibly from a door or chest. The few nails scattered over the site are probably mostly post-medieval.

$L B 540 / 54^{*} \quad$ Iron blade with perforation at one end. Section is flat, not triangular like a knife. Corroded and broken in two pieces. I $30 \times 13-22 \mathrm{~mm}$, T. $1.5 \mathrm{~mm}$. $1988 \mathrm{E}$ (18).

LB $\quad$ Nail, flat square head, $18 \times$ I $8 \mathrm{~mm}$, shaft $5 \mathrm{~mm}$. I $988 \mathrm{E}(26)$.

$L B 73^{8^{*}} \quad$ Nail, head round D. $26 \mathrm{~mm}$, shaft square $8 \times 8 \mathrm{~mm}, \mathrm{~L} .32 \mathrm{~mm}$. I $989 \mathrm{E}$ (4I).

$L B 784 \quad$ Nail, round head D. $20 \mathrm{~mm}$, shaft square section, curved, L. Io mm. $1989 \mathrm{E}(4 \mathrm{1})$.

LBgIG Nail, round head D. $20 \mathrm{~mm}$, shaft square, L. I3 mm. Ig8g E (52).

IMPORTED EARLY MEDIEVAL POTTERY

The variety of early medieval import wares is matched in Britain and Ireland only at Dinas Powys and Whithorn, ${ }^{79}$ though the number of vessels in each class is not large (Fig. 6). In summary, the imports consist of one Phocaean Red Slipware (PRS) dish; one B $i$, one or two $\mathrm{B} i i$, one $\mathrm{B} i v$ and one or two $\mathrm{B}$ misc Mediterranean amphorae; a mortarium and a plate of D ware; and five $\mathrm{E}$ ware vessels. The imports have most recently been studied in detail by one of the authors (ENC), which forms the basis of the discussion. ${ }^{80}$

\section{Phocaean Red Slipware (A ware) Fabric A ${ }^{81}$}

There are 13 sherds, all of which could be from the same Form 3 vessel, though they are spread over all the excavated areas.
$L B_{4.32}$
Bodysherd, abraded. Max. S. 2 cm. 1989 C $(64)$.
$L B_{435}$
Base sherd with abraded stamp (unrecognizable). Edges with rodent toothmarks, abraded. Max. S. $2 \mathrm{~cm}$. $1989 \mathrm{C}(64)$.
$\mathrm{LB}_{4} 6_{5} \quad$ Bodysherd, abraded. Max. S. $3 \mathrm{~cm}$. T. $4 \mathrm{~mm}$. $1989 \mathrm{C}(74)$. 

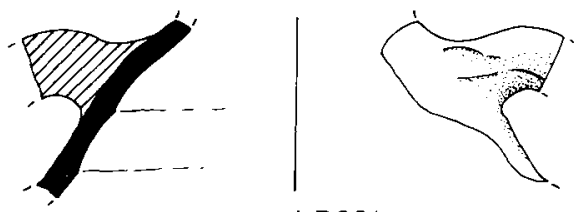

LB601
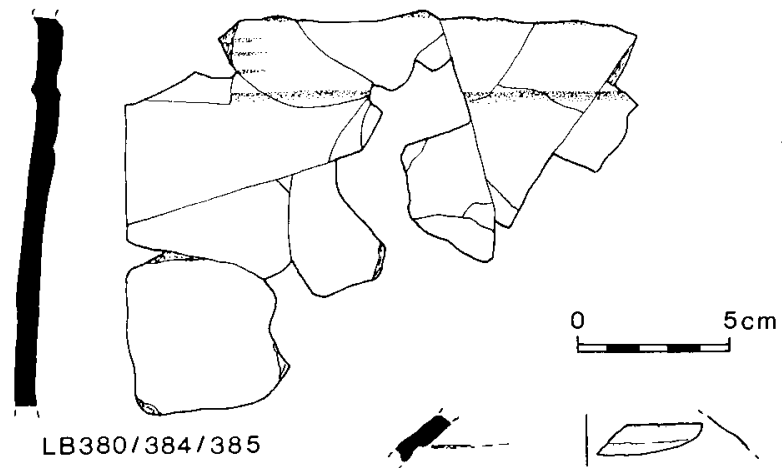

NC3
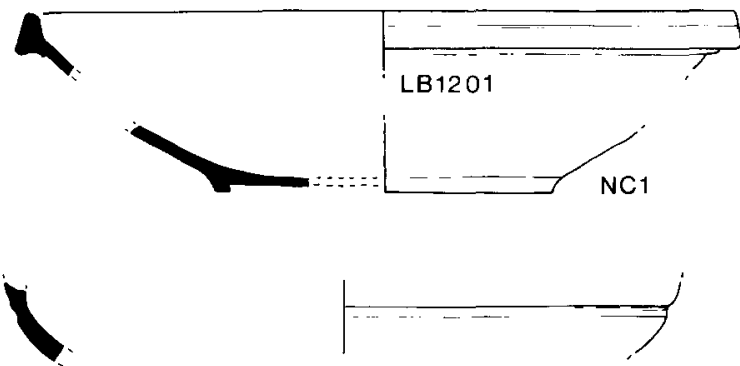

NP1436

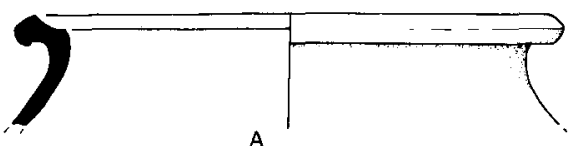

A
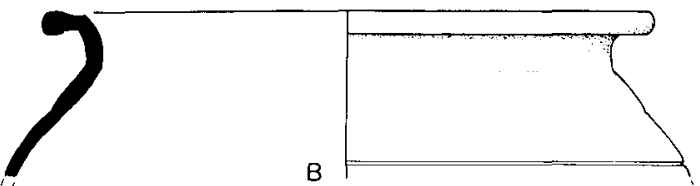

FIG. 6

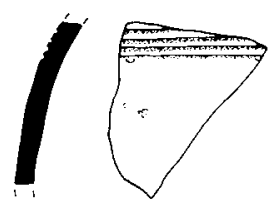

LB603
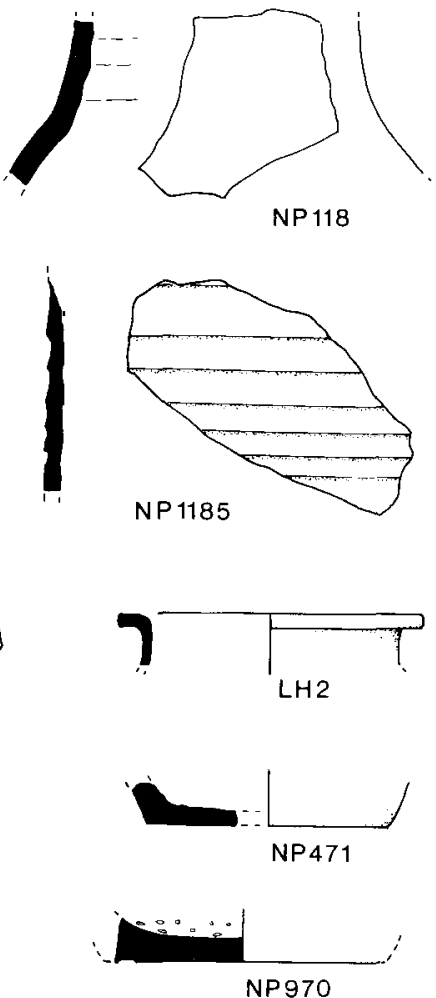

NP970

Imported pottery: $\mathrm{B} i, L B 601, L B 603 ; \mathrm{B} i, L B 380 / 38_{4} / 385, N P_{I I} 8_{5} ; \mathrm{B}$ misc. NPII 8 , with graffito cross, $N_{1323}$; Biv NG 3 ; Phocaean Red Slipware, LBI20I, NCI; D ware, NP97o, NPI436; E ware, LB57, $\mathrm{LB}_{317}, \mathrm{LH} 2, \mathrm{NP} 47^{I}, N \mathrm{P}_{1339}$. E ware from Linney Burrows: A.; and Carew Castle: B. Scale I:3 
LB829 Bodysherd, abraded. Max. S. I cm. T. 2 mm. 1989 B (28).

$\angle B_{120 I^{*}}{ }^{*} \quad$ Rim of dish with single groove on outer face and offset below. Hayes Form $3 \mathrm{E}$. Slip almost all abraded. Rim D. $24-6 \mathrm{~cm}$. Max. S. $4 \mathrm{~cm}$. T. $3 \mathrm{~mm}$. I $989 \mathrm{H}(\mathrm{r})$.

$\mathrm{NCI}^{*} \quad$ Basal part of dish with footring and part of abraded stamp. Hayes Form 3 . At least eight sherds survive. Abraded, but slip survives in interior. Basal stamp unrecognizable. Base D. I cm. Max. S. $5 \mathrm{~cm}, 2 \times 4 \mathrm{~cm}, 3 \mathrm{~cm}, 3 \times 2 \mathrm{~cm}$, I cm. $1877-78$, shaft of N. cave. Tenby Museum ig88. 2261.

$B$ ware amphorae Fabrics: $\mathrm{B} i=\mathrm{B}_{1}, \mathrm{~B} i i=\mathrm{B}_{2}, \mathrm{~B} i v=\mathrm{B}_{4}$

There are $6_{5}$ sherds from four to six vessels.

$L B_{3} 80 / 3^{8} 4 ! \quad 32$ sherds and a number of fragments of a large section of a $B i i$ amphora. 16 sherds join $385^{*}$ to form a piece $\mathrm{I}_{3} \times{ }_{1} 7 \mathrm{~cm}$. The upper part has two tegulated ribs $2.5 \mathrm{~cm}$ apart, the lower part is plain. The interior has strong rilling. 'T. $7-8 \mathrm{~mm}$. Max. D.c. $40 \mathrm{~cm}$. Colour ranges from buff to orange-brown to grey. Vessel burnt in places, with rodent teeth marks on some edges and surfaces. Some sherds fresh, some abraded. I 988 B (15).

LB60I* Handle and neck of $B i$ amphora. Handle oval in section, $31 \times 22 \mathrm{~mm}$, luted to body. Body T. $6-8 \mathrm{~mm}$, exterior smoothed, interior with strong finger-rilling. Colour buff with red-orange core, interior with black deposit. Abraded. I988 D (2).

$L B 602 \quad$ Bodysherd with combed decoration. Colour and fabric as $L B 60 I$, probably same vessel. T. $6 \mathrm{~mm}$. Grooves incised, six in $16 \mathrm{~mm}$. Abraded. I $988 \mathrm{D}(3)$.

LB603* $^{*} \quad$ Bodysherd with combed decoration. Probably same vessel as $L B 60 r$. T. $7 \mathrm{~mm}$. Max. D. . $28 \mathrm{~cm}$. Abraded. I $988 \mathrm{D}(3)$.

$L B 74^{\circ} \quad$ Five joining bodysherds of Bmisc. amphora. Fabric B6. Very abraded. Max. D. $c .34 \mathrm{~cm}$. $8 \times 8 \times 0.9 \mathrm{~cm}$. $1989 \mathrm{E}(4 \mathrm{I})$.

$L B 781 / 729$ Three bodysherds of Bmisc. amphora. Fabric B6. T. $8 \mathrm{~mm}$. $1989 \mathrm{E}\left(4^{\mathrm{O}} / 4 \mathrm{I}\right)$.

$L B 818$

$L B g 8 I$

$L B 1231$

$L B_{1247}$

LHI

Bodysherd of $\mathrm{B} i$ amphora, undecorated. Very abraded. $3 \times 2 \times 0.5 \mathrm{~cm}$. I989 B (30).

Bodysherd of $B i$ amphora. Very abraded. I $\times$ I cm. I $989 \mathrm{E}(76)$.

Possible sherd of $\mathrm{B} i$. Abraded. $1989 \mathrm{H}(2)$. $\mathrm{H}(2)$

$\mathrm{LH}_{4}$

$\mathrm{NC2}$

$N C_{3}{ }^{*}$

$N P_{I I}$

$N P_{112}$

$N P_{I I} 8^{*}$

$N_{4}{ }^{\circ} 3$

$N P_{4 I I}$

NP60I

$N P_{11} 85^{*}$

Two bodysherds of Bii amphorae, very abraded. Max. S. $4 \mathrm{~cm}$ and $3 \mathrm{~cm}$. $1958 \mathrm{NP}_{2}$ ?basal deposits, disturbed.

Bodysherd of Biv amphorae. 1958 topsoil. Acc. No. 63.7/1.

Bodysherd of Bi amphora with combed decoration. Unabraded. $3 \times 3 \mathrm{~cm} . \mathrm{T} .0 .9 \mathrm{~cm}$. I 877-78 'N. cave'. Tenby Museum I988. 226I.

Bodysherd of Biv amphora, from near shoulder. Fabric $\mathrm{B}_{4}$. Abraded. $3.5 \times 2 \mathrm{~cm}$. I877-78 ' $\mathrm{N}$. cave'. Tenby Museum 1988. 226I.

Bodysherd of Bmisc. amphora. Fabric B 3 . Abraded. $90 \times 45 \times 9$ mm. I $98_{4} \mathrm{NPI}_{\text {(I). }}$ (I)

Bodysherd of B $i$ amphora. Very abraded. $20 \times 2 \mathrm{I} \times 6 \mathrm{~mm}$. $1984 \mathrm{NPI} . \mathrm{B}(4)$.

Bodysherd of Bmisc. amphora, near neck. Fabric B $3.80 \times 55$ mm. 1984 NPr.B (4).

Bodysherd of Bmisc. amphora. Fabric B3. Abraded. $7 \times_{5} \times \mathrm{I} \mathrm{cm}_{3} \mathrm{I}_{986} \mathrm{NP}_{4}$ ( $\mathrm{I}_{3}$ ).

Bodysherd of Bmisc. amphora. Fabric B 3 . Unabraded. $6 \times 4.5 \times 1 \mathrm{~cm}$. $1986 \mathrm{NP}_{4}$ ( ${ }_{3}$ ).

Bodysherd of Bmisc. amphora. Fabric B3. $3 \times 3 \times 0.8 \mathrm{~cm}$. $1986 \mathrm{NP}_{4}\left(3 / \mathrm{I}_{3}\right)$.

Bodysherd of $\mathrm{B} i$ amphora, exterior with tegulated ribs $8 \mathrm{~mm}$ apart widening upwards to $18 \mathrm{~mm}$ apart. Interior with black deposit, but analysis showed no resin. Buff/grey. Max. D. $36 \mathrm{~cm}$. I Io $\times 55 \mathrm{~cm}$. I $990 \mathrm{NP}_{1} . \mathrm{C}_{3}(2)$.

NPI259 Bodysherd of Bmisc. amphora. Fabric B3. Abraded. $6 \times_{4} \times$ I.2 cm. I990 NPr.F2 (r).

$N P_{130 I} \quad$ Bodysherd of Bii amphora with tegulated ribs. $4 \times 3 \mathrm{~cm}$. $1990 \mathrm{NPI} \mathrm{CI}_{1}(2)$.

NPI323* Bodysherd of Bmisc. amphora with inscribed cross graffito. Fabric $\mathrm{B}_{3.45} \times 35 \times 8 \mathrm{~mm}$. $1990 \mathrm{NP}_{1} . \mathrm{F}_{3}(2)$. 
NPI326 Bodysherd of Bii amphora. Very abraded. I.5 I $_{1} \mathrm{~cm}$. I990 NPI.CI (2).

NPI $470 \quad$ Bodysherd of B $i$ amphora. Very abraded. $2 \times 2 \mathrm{~cm}$. I 990 NPI.EI (2).

RI4 Bodysherd of Bmisc. amphora. Fabric B3. Abraded. $55 \times 40 \times$ I I mm. ${ }_{9} 84$ R I (I) spit 2 .

$D$ ware Fabric DI

The three sherds belong to at least two vesscls, a mortarium and a plate.

$\mathrm{LB}_{524}$ Small bodysherd of D ware mortarium, Rigoir form 29. T. $6 \mathrm{~mm}$. Colour pale olivegrey. Fabric fine, soft, few grits except occasional decomposed limestone lumps. Interior has trituration grits up to $3 \mathrm{~mm}$ of white sub-rounded quartz. No trace of slip on any surface but sherd is abraded. $1988 \mathrm{E}$ (3).

NP970* Base sherd of mortarium Rigoir Form 29. Interior with trituration grits. Basal angle with characteristic pseudo-footring. Basal D. Io cm. Very abraded. $5 \times 4 \times 0.8 \mathrm{~cm}$. I $986 \mathrm{NP}_{4}\left(3 / \mathrm{I}_{3}\right)$.

$N_{1436} \quad$ Bodysherd from just below rim. Shallow external groove $4 \mathrm{~mm}$ wide. Probably from plate Rigoir Form 4. Pale grey, no slip. Abraded. Rim D. ?22-24 cm. $35 \times 28 \times 6 \mathrm{~mm}$. I $990 \mathrm{NPI}_{1} \mathrm{~F}_{4}(2)$.

\section{Eware Fabric EI}

There are 22 sherds, from at least four vessels, including three jars and one small jar.

$L_{557^{*}} \quad$ Rim of $\mathrm{E}_{1}$ jar. Strongly everted rim with external overhang and internal lid-seat. Colour, cream to buff with grey patch on rim. Occasional orange-brown iron ore. Surfaces wet-smoothed but with grits protruding to give pimply texture. Unabraded. Rim D. I6 cm. T. 5-7 mm. 1988, C (4). Plough-soil.

LBgo Bodysherd. Buff to grey. Abraded. $27 \times 17$ mm. T. 4 mm. 1988 C (12). Plough-soil.

$L B_{3 I 7^{*}} \quad \operatorname{Rim}$ of $\mathrm{E}_{\mathrm{r}}$ jar. Simple everted rim with angular profile, no lid seat. Colour black exterior to buff interior. Unabraded. Rim D. $16 \mathrm{~cm}$. T. $7 \mathrm{~mm}$. $1988 \mathrm{~B}(3)$. Topsoil.

LB54I Bodysherd. Colour black exterior to buff interior. Abraded. $29 \times$ I 7 mm. T. 4 mm. I 988 E (3). Plough-soil.

LB57I Bodysherd. Colour black exterior to off-white interior. Abraded. $24 \times$ I $7 \mathrm{~mm}$. T. 4 mm. I 988 E (26). Post-hole (6).

LB588 Bodysherd. Colour black exterior to pink-buff interior. Unabraded. $25 \times 26 \mathrm{~mm}$. T. 4-5 mm. $1988 \mathrm{E}(35)$. Post-hole (6).

LB605 Bodysherd. Black. Abraded. $25 \times 18 \mathrm{~mm}$. T. $4 \mathrm{~mm}$. $1988 \mathrm{D}(3)$. Hill-wash.

LB6I4 Two bodysherds: a) $26 \times 20 \mathrm{~mm}$, T. $4 \mathrm{~mm}$, colour and fabric as $L B 605$. b) $20 \times 15 \mathrm{~mm}$, $\mathrm{T} .4 \mathrm{~mm}$, colour exterior orange-brown, interior black to grey. Unabraded. $1988 \mathrm{D}(3)$. Hill-wash.

$\mathrm{LH}_{2}{ }^{*} \quad$ Rim of small $\mathrm{E}$ ware vessel, form $\mathrm{E}_{2 \mathrm{~B}}$. Rim simple, everted at $90^{\circ}$, rectangular profile, neck vertical. Surface abraded. $4 \times 1.7 \mathrm{~cm}$, T. 3-5 mm. Rim D.c. Io cm. 1959 bag ?88. NP2. Acc. No.8r.85h.

$\mathrm{LH}_{3} \quad$ Bodysherd of $\mathrm{E}$ ware, $\mathrm{E}_{\mathrm{r}}$ jar form. Burnt, unabraded. Max. D. c. $16 \mathrm{~cm}$. T. 4-5 mm. I958 $\mathrm{NP}_{2}$, topsoil. Acc. No.63.7/2.

NPI97 Bodysherd, broken just above base. Sooted. Fabric E I, but with many rounded quartz grains, no iron ore. $55 \times 50 \mathrm{~mm}$, T. 6-1o mm. $1984 \mathrm{NP}_{3}$ (viii) (2), topsoil.

NP404 ?Basal angle, very obtuse angle. Unsooted, unabraded. Black/grey/cream. $50 \times 38 \mathrm{~mm}$. $1984 \mathrm{NP}_{3}$ (13), topsoil.

$N_{47 I^{*}} \quad$ Base of $\mathrm{E}_{2}$ beaker, cut-off faint. Fabric Er, some orange iron ore. Black/grey/cream. Base D. $10 \mathrm{~cm}, 40 \times 30 \mathrm{~mm}, \mathrm{~T} .5-6 \mathrm{~mm}$. $1984 \mathrm{NP}_{3}(3 / \mathrm{r} 3)$, topsoil or backfill.

NP1216 Two tiny bodysherds. Off-white. Unabraded. I $5 \times 1$ I mm; 10 $\times 7 \mathrm{~mm} ; \mathrm{T} .4 \mathrm{~mm}$. I990. NPI.CI ( I), hill-wash. 
$N P_{1339^{*}} \quad$ Rim of $\mathrm{E}_{\mathrm{r}}$ vessel. Rim everted at almost $90^{\circ}$, slightly thickened, bevelled profile. Faint lid seat. Unabraded. Fabric EI, with orange rounded iron ore. Very similar to $L B_{3}{ }_{17}$, but not the same vessel. Rim D. I $8 \mathrm{~cm}, 50 \times 32 \mathrm{~mm}$, T. $5 \mathrm{~mm}$. I 990 NPI.E2nw (I), topsoil.

NP1365 Bodysherd. Black. Unabraded. $29 \times 25 \mathrm{~mm}, \mathrm{~T} .5 \mathrm{~mm}$. I990 NPI.E2sw (I), hill-wash.

NPI4I8 Bodysherd. Grey/buff/grey. Abraded. I $8 \times$ I $8 \mathrm{~mm}$, T. $4 \mathrm{~mm}$. I 990 NPI.F 4 (2), hillwash.

NPI473 ?Basal sherd. Large diameter, no sooting. Abraded. White/pinkish buff. Fabric unusual, much tiny mica, some rounded quartz, rich in iron ore. One ore grain contains angular quartz grains. $47 \times 35 \mathrm{~mm}$, T. 4-6 mm. I 990, Area NPr. Einw (2), hill-wash.

RI5 Bodysherd. Grey/black. Very abraded. $20 \times 17 \times 4 \mathrm{~mm}$. I $984 \mathrm{R}_{\mathrm{I}}$ (I) spit 2, topsoil.

$R_{32} \quad$ Bodysherd. Black/cream/black. Very abraded. $20 \times$ I $_{5} \times 3-4 \mathrm{~mm}$. I984 R I (I) spit 2 , topsoil.

\section{Possible imports}

$L B_{5 O I} \quad$ Rim and wall of small ?bowl. D. I $2 \mathrm{~cm}$. T. 5-7 mm. Flat-topped rim with everted squared outer lip. Deep incised groove runs along basal angle. Fabric soft, highly micaceous with white mica platelets up to I mm, scattered angular quartz and common red iron ore and cream clay pellets. Area E (I). Plough-soil. Perhaps Spanish, post-medieval, but form is unusual.

$\mathrm{LBgO}_{3} \quad$ Bodysherd from large vessel. Fabric pale pink, well fired, abundant mica and poorly sorted quartz up to $\mathrm{I} \mathrm{mm}$, sub-angular to rounded, occasional felspar and red iron ore. $4 \mathrm{~cm}$, T. $6 \mathrm{~mm}$. $1989 \mathrm{E}\left(5^{6}\right)$.

LBg67 Bodysherd of ?amphora with internal rilling. Exterior has vertical impressions which retain red slip. Fabric pale orange, medium hard, inclusions much white mica, tiny quartz and dark minerals, with large yellow clay pellets. $3 \times 3 \mathrm{~cm}$, T. $6 \mathrm{~mm} .1989$ E (73). ?Mediterranean.

SVI Bodysherd of red-slipped bowl. Red slip on exterior, soft orange fabric. Sparse well-rounded quartz inclusions, many tiny cavities. $26 \times 24 \times 7 \mathrm{~mm}$. ?African Red Slipware, or ?Late Roman colour coat.

\section{DISCLSSION OF THE IMPORTED POTTERY}

The PRS dish is of Hayes' Form ${ }_{3} \mathrm{E}$, datable to $c$. A.D. 500 , and known to have been manufactured in western Turkey. ${ }^{82}$ The edge of a now unidentifiable stamp remains on the base but early accounts speak of this as a small fragment of 'incised animal figures' ${ }^{83}$ If this is an accurate description of the type of decoration it would belong to Hayes' stamp Group II or early Group III and confirm a date in the last quarter of the 5 th century or around A.D. $500 .{ }^{84}$ The identifiable $B$ ware amphorae are of $\mathrm{E}$. Mediterranean origin: $\mathrm{B} i$ from the Peloponnese, $\mathrm{B} i i$ probably from SE. Turkey and Biv from W. Turkey. ${ }^{85}$ These amphorae were used as containers for wine, olive oil and other exotic products, though none of these contents have yet been specifically detected in British sherds. ${ }^{86}$ The vessels are not closely datable in themselves, especially when the details of the form are unknown, but they belong to a phase of importation which can be dated by the accompanying fine wares to the period A.D. 475$55^{0 .}{ }^{87}$ One of the Bmisc. amphorae (here Fabric $\mathrm{B}_{3}$ ) bears a strong superficial resemblance to a Spanish Dressel 20 amphora, but differs in the mineralogy of the temper. Keay's work on Spanish amphorae shows that production continued into the $5^{\text {th }}$ and 6 th centuries, so it is possible that this is a post-Roman Spanish import, rather than a Roman period residual vessel. ${ }^{88}$ The graffito cross on $N_{1323}$ is matched by a recent find from Whithorn Priory on a Bii amphora. ${ }^{89}$ The $D$ ware vessels are typical examples of the late stamped and rouletted pottery of W. Gaul belonging to Rigoir's Atlantic Group of the dérivées sigillées paléochrétiennes, and can be dated to the 6 th century. ${ }^{90}$ Mortaria, though rare in the French assemblages, are common in Insular contexts, being found on seven of the ten known D ware sites. The $E$ ware vessels can be dated to the late 6 th to late 7 th century, and although the exact provenance is 
unknown it is probably somewhere in NW. or W. France. The forms at Longbury Bank are all varieties of the olla or jar, by far the commonest $\mathrm{E}$ ware vessel form. One vessel, $\mathrm{LH}_{2}$, and its possible base, $N P_{47 I}$, is a small form of jar which is uncommon but is represented by three cxamples from Dinas Powys. ${ }^{91}$ The fabric of another vessel, NPI473, is unusual and is identical to that of a previously unpublished $\mathrm{E}$ ware vessel from Carew Castle (Fig. 6, B) which lies only $8 \mathrm{~km}$ to the W. of Longbury Bank. ${ }^{92}$

ROMAN POTTERY

NPI7O Rim and part of handle attachment. Rim L-shaped, everted at $90^{\circ}$ with groove on upper surface, square profile. Unabraded. Fabric XI. Rim D. c. $26 \mathrm{~cm}, 75 \times 35 \mathrm{~mm}$. $\mathbf{I}_{984}$ NPi.B(i) (5).

NPI590 Bodysherd of small vessel. Fabric hard, white or grey core with black ?slipped surfaces, exterior appears to be burnished and has micaceous feel. Inclusions of sparse rounded quartz up to $2 \mathrm{~mm}$, much tiny quartz in groundmass. $30 \times 17 \times 6 \mathrm{~mm}$. I $990 \mathrm{NPI}$ surface find.

SC69 Bodysherd of blackware, same vessel as NPI59o. Unabraded. I986 SC (3).

Only one sherd is certainly Romano-British, $N P_{I 7}$, which is from a type of vessel known as a 'honey jar', a form commonest in I st century contexts though it does occur later. ${ }^{93}$ 'The sherd is remarkably fresh and unabraded. The blackware sherds are probably Roman but have no distinguishing features. Other possible sherds of this period include the amphora listed under the $\mathrm{B}$ misc. category with Fabric $\mathrm{B}_{3}$, and $S V_{I}$ listed as a possible import.

\section{IMPORTED EARLY MEDIEVAL GLASS}

The glass is the most abundant import on the site, with 63 sherds belonging to at least 15 vessels which can be distinguished on the basis of form, colour, decoration, metal and inclusions. The vessels are of continental origin and differ from those found in contemporary Anglo-Saxon England. The forms are all drinking vessels (Fig. 7).

\section{Continental imports}

Vessel 1 : Cone beaker, undecorated, very pale yellow.

LB580 Bodysherd, few bubbles. I $\times 6 \times$ I.5 mm. $1988 \mathrm{E}(23)$.

$L B 75 I^{*} \quad$ Bodysherd. I6 $\times 10 \times 0.5 \mathrm{~mm}$. I989 E $(4 \mathrm{I})$.

$L B 793^{*} \quad$ Rim, fire-rounded, thickened internally. Few bubbles, fine metal. Wear marks on surface of rim. $27 \times 21 \times$ I mm. D. Io cm. $40^{\circ}$ rim survives. $1989 \mathrm{E}(56)$.

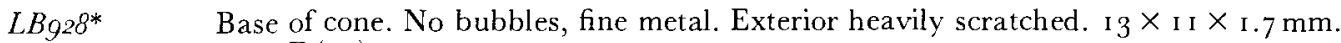
$1989 \mathrm{E}\left(5^{2}\right)$.

Vessel 2: Deep cup/shallow funnel beaker decorated with horizontal marvered white trails below rim and unmarvered spiral trails around base, olive green. The glass analyses (Table 2) suggest that the rim and base sherds may in fact belong to different vessels.

LBg23 $^{*} \quad$ Rim, fire-rounded and thickened. Below the rim are three fine bands of horizontal opaque white marvered trails. Fine metal, bubbles. Exterior scratched. $2 \mathrm{I} \times \mathrm{I} 7 \times \mathrm{I} .2 \mathrm{~mm}$. D. c. $8 \mathrm{~cm} .32^{\circ}$ survives. $1989 \mathrm{E}(56)$.

LB937/924* Joining sherds from near base. Three spiral trails, opaque white unmarvered. Projecting scar cutting trails is part of annular? pontil mark. Few bubbles, fine quality. ${ }_{13} \times \mathrm{i} \mathrm{mm}$ and $7 \times 4 \mathrm{~mm}$, T. I.3-2.0 $\mathrm{mm}$. i $989 \mathrm{E}\left(7 \mathrm{I} / 5^{6}\right)$.

Vessel 3: Vessel decorated with thick unmarvered self-coloured trails in loop or zig-zag pattern, colourless. Perhaps from a wide beaker or cup.

LBII44* Bodysherd decorated with $3 \mathrm{~mm}$ thick applied trail in high relief, unmarvered, self-coloured. Trail, 2-3 mm wide, is top of loop or chevron. Colourless or very pale 

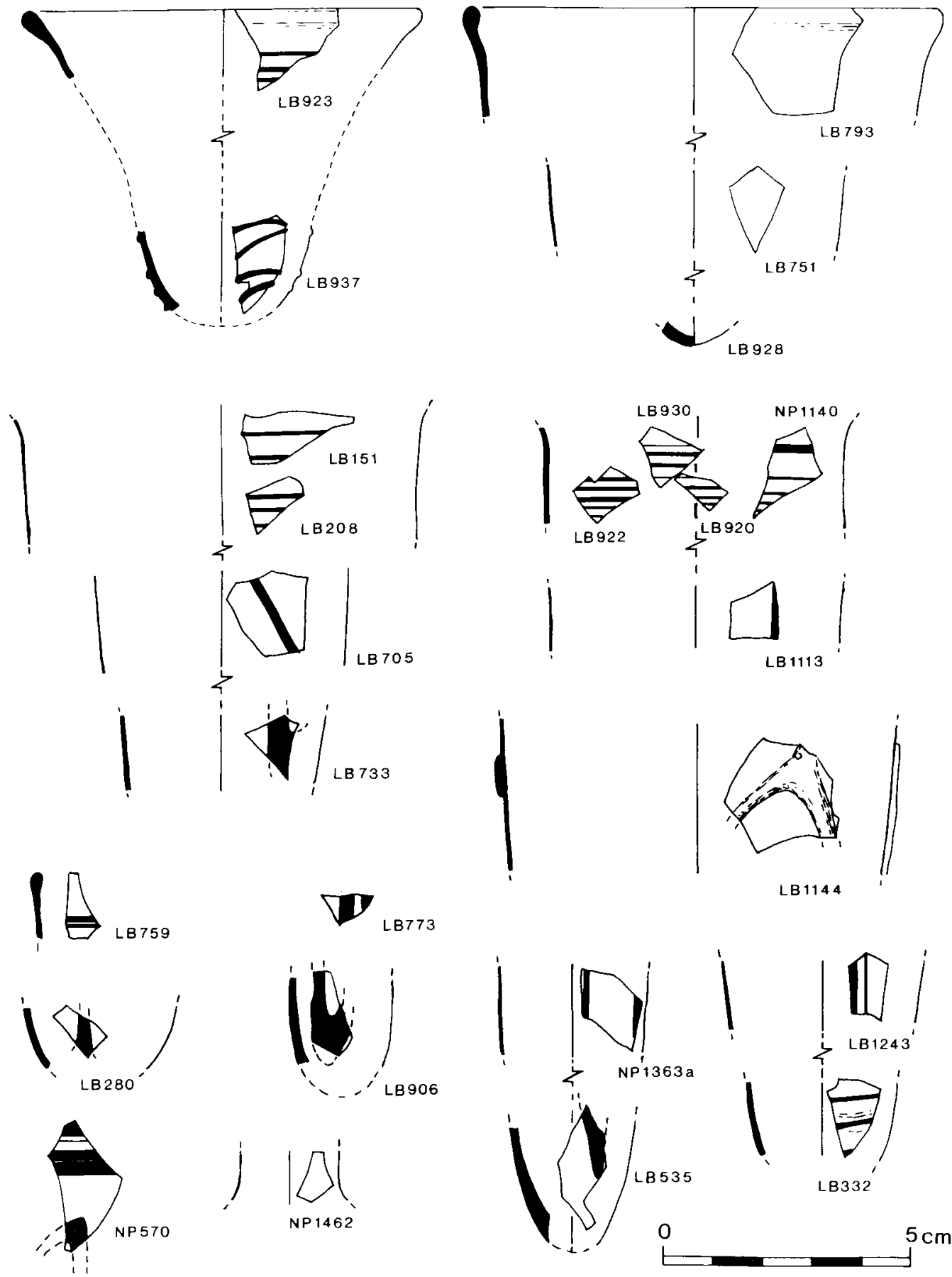

FIG. 7

Continental glass. Vessel 2, $L B 923, L B 937$; Vessel i, $L B 751, L B 793, L B 928$; Vessel $6, L B_{15}$, $L B 208$, $L B 705, L B 733$; Vessel io, LB920, LB922, LB930, LBIII3, NPII4O; Vessel 3, LBII44; Vessel 4 , LB280, $L B 759$; Vessel 9, $L B_{773}, L B 906$; Vessel 7, $L B_{535}, N P_{13} 6_{3} a$; Vessel i $2, L B_{124}, L B_{334}$; Vessel $5, L B_{34} 6$ Possible import NPI 462 . Scale c. $3: 2$ 
green, with occasional bubbles. Many bubbles in trail. Exterior badly decayed and blackened, irridescent. $25 \times 20 \times 0.4 \mathrm{~mm}$. D. c. $8 \mathrm{~cm}$. $1989 \mathrm{E}(88)$.

LBII 4.9 Tiny bodysherd with decayed trail on surface which is badly decayed and irridescent. Colourless. $5 \times 5 \times 0.2 \mathrm{~mm}$. $1989 \mathrm{E}(88)$.

Vessel 4: Cone beaker with white marvered trails in horizontal bands below rim and vertical chevrons on body, very pale yellow.

$\angle B 280^{*} \quad$ Base of cone beaker, with vertical opaque white marvered trail expanding downwards. Scattered round bubbles up to I $\mathrm{mm}$, exterior scratched. $\mathrm{I} 2 \times 6 \times \mathrm{I} .5 \mathrm{~mm}$. D. $c .2 \mathrm{~cm}$. I $988 \mathrm{~B}(3)$.

$L B 759^{*} \quad$ Rim, fire-rounded and thickened. Below are two bands of opaque white horizontal marvered trails, each band of several fine threads. Metal of high quality. $8 \times$ i $3 \mathrm{~mm}$, T. I mm. $5{ }^{\circ}$ survives. $1989 \mathrm{E}(4 \mathrm{I})$.

LB943 Bodysherd. $6 \times 4 \times 1.7$ mm. $1989 \mathrm{E}(7 \mathrm{I})$.

$L B g 88 \quad$ Bodysherd with part of a vertical opaque white marvered trail. $8 \times 5 \times 0.8 \mathrm{~mm}$. 1989 $\mathrm{E}\left(7^{2}\right)$.

Vessel 5: Cone beaker with marvered white trails in horizontal band below rim and vertical chevrons. Pale yellow.

$N_{57 O^{*}} \quad$ Bodysherd from below rim with bands of thin horizontal opaque white marvered trails above the pointed tip of a chevron. $26 \times_{13} \mathrm{~mm}$. D. $6 \mathrm{~cm}$. I $986 \mathrm{NP}_{4}(3 / \mathrm{r} 3)$. On loan toTenby Museum.

Vessel 6: Cone beaker with band of white trails below rim and vertical chevrons on body, colourless.

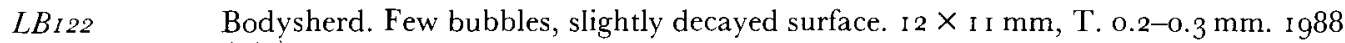
A (3).

$L_{15 I^{*}} \quad$ Bodysherd of large vessel with three horizontal opaque white marvered trails. Few bubbles. Outer surface cloudy and sherd slightly distorted. $22 \times 10 \times 1 \mathrm{~mm} .1988$ A ( I ).

LBI55 Bodysherd. Tiny bubbles. $9 \times 5 \mathrm{~mm}$, T. o. $5 \mathrm{~mm}$. I988 A (1).

$\angle B 208^{*} \quad$ Bodysherd from just below rim with three horizontal opaque white marvered trails. Few tiny round bubbles. Surface clouded, partly decomposed. I $\times$ I I $\times$ I mm. D.c. $8 \mathrm{~cm} .1988 \mathrm{~B}(\mathrm{I})$.

$L B 705^{*} \quad$ Bodysherd, outer surface with faint ?moulded diagonal ribbing, with one parallel opaque white marvered trail, decomposed. Few bubbles. ?Cone beaker ${ }^{94}{ }_{1} 7 \times{ }_{1} 6 \mathrm{~mm}$, T. $0.2-0.3 \mathrm{~mm}$. D. $.5 \mathrm{~cm}$. I $988 \mathrm{E}$ Unstrat.

$L B 733^{*} \quad$ Bodysherd near base, with vertical opaque white marvered trail from base of chevron. I $2 \times$ I I $\times 0.6 \mathrm{~mm}$. $1989 \mathrm{E}(4 \mathrm{I})$.

$L B 78_{5} \quad$ Bodysherd. $6 \times 4 \times 0.4 \mathrm{~mm} .1989 \mathrm{E}(4 \mathrm{I})$.

$N P_{704}$

Bodysherd with six horizontal decayed opaque white partially marvered trails. One vertical bubble. $17 \times_{12} \times 0.5 \mathrm{~mm}$. D.c. $6 \mathrm{~cm}$. $1986 \mathrm{NP}_{4}$, unstrat.

NP7o6a Bodysherd with three vertical opaque white marvered trails, decayed, one $\mathrm{I} .5 \mathrm{~mm}$ wide. Few vertical bubbles. $15 \times 9 \times 0.7 \mathrm{~mm}$. D. $3-4 \mathrm{~cm}$. $1986 \mathrm{NP}_{4}$.J8nw (3a).

$N P$ 7o6b Bodysherd with one vertical opaque white decayed trail. Surface irridescent, a few round bubbles. $17 \times$ I I $\times 0.2 \mathrm{~mm}$. D. $c .5 \mathrm{~cm}$. I $_{9} 86 \mathrm{NP}_{4}$.J $8 \mathrm{nw}$ (3a).

$\mathrm{NP}_{13}{ }_{3} \mathrm{~b} \quad \mathrm{~B}$ Bodysherd with two vertical opaque white marvered trails, one $3 \mathrm{~mm}$ wide. Few large vertical bubbles, interior crazed. I $_{3} \times 9 \times$ I mm. D.c. $5 \mathrm{~cm}$. I $990 \mathrm{NPI}_{2} \mathrm{~F}_{3}$ (2) sieve.

$N P_{1457}$ Bodysherd with two vertical opaque white marvered trails, one decayed, one at least $2 \mathrm{~mm}$ wide. $8 \times 5 \times 0.8 \mathrm{~mm}$. I $990 \mathrm{NPI} . \mathrm{E}_{\mathrm{I}}(2)$.

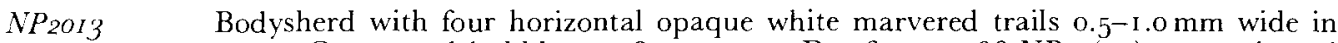
$7 \mathrm{~mm}$. One round bubble. $9 \times 8 \times 0.5 \mathrm{~mm}$. D. $c .6 \mathrm{~cm}$. $1986 \mathrm{NP}_{4}$ (II) contaminated sieve. 
Vessel 7: Cone beaker with white-trailed vertical chevron decoration, very pale greenish yellow.
LB535*
Base of cone beaker, with base V-shaped vertical opaque white trail expanding upwards. Bubbles abundant up to $0.5 \mathrm{~mm}$, in vertical trails, slightly elongated vertically, exterior worn. $24 \times$ Io mm, T. $2-3 \mathrm{~mm}$. D.c. $3 \mathrm{~cm}$. $1988 \mathrm{E}(3)$.
NP273 Bodysherd from near base, distorted by heat. Traces of two vertical trails, completely decayed, one $2.5 \mathrm{~mm}$ wide and narrowing, one $1.5 \mathrm{~mm}$ wide. Surface bubbly, decayed. Yellow-green, irridescent. $16 \times 18 \times 0.7 \mathrm{~mm}$. D. $2 \mathrm{~cm}$. $1984 \mathrm{NP}_{3}$ (ii). (3).
$N_{13} 6_{3} a^{*} \quad$ Bodysherd from towards base of cone with two vertical opaque white marvered trails, partially decayed. Trails I $\mathrm{mm}$ and $1.5 \mathrm{~mm}$ wide. Large vertical bubbles up to $3 \mathrm{~mm}$

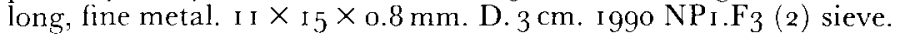
NPI42I Bodysherd with faint traces of decayed horizontal trails. $23 \times_{\text {I I }} \times_{\text {I }} \mathrm{mm}$. D.c. $6 \mathrm{~cm}$. 1990 NPi.Dise (2).

Vessel 8: Vessel of unknown form with horizontal ridging and possible white trails, very pale greenish yellow.

LB706 Bodysherd, surface with fine ridging and eroded bubble pits, possibly one decayed horizontal trail. Large bubbles up to $1 \mathrm{~mm}$. $16 \times 9 \times \mathrm{I} .2 \mathrm{~mm}$. $1988 \mathrm{E}$ Unstrat.

Vessel 9: Cone beaker with white trailed decoration of vertical chevrons, pale green.

$L B 773^{*} \quad$ Bodysherd with two wide vertical opaque white marvered trails. Bubbles, fine metal. Io $\times 7 \times$ I. I mm. Ig89 E (41).

LB8I7 Bodysherd. I I $\times 6 \times 0.6 \mathrm{~mm}$. ig89 B (28).

$L B 906^{*} \quad$ Bodysherd from near base of cone. Opaque white marvered trail, vertical loop or chevron. Bubbles, fine metal. $16 \times 18 \times$ I mm. $1989 \mathrm{E}\left(5^{6}\right)$.

$\angle B_{91} 8 \quad$ Bodysherd. $9 \times 4 \times 0.7 \mathrm{~mm}$. $1989 \mathrm{E}\left(5^{6}\right)$.

Vessel Io: Cone beaker with white trails in band below rim and in vertical chevrons, pale yellow-green.

LB823 Bodysherd. $8 \times 3 \times 0.6 \mathrm{~mm} .1989 \mathrm{~B}(3 \mathrm{r})$.

$\angle B 920^{*} \quad$ as $L B 930$. 10 $\times 6 \times 0.7 \mathrm{~mm}$.

LB922/76 $4^{*} \quad$ Joining bodysherds with six horizontal opaque white marvered trails. Few bubbles. $7 \times 8 \mathrm{~mm}$ and $5 \times 8 \mathrm{~mm}$. T. $0.8 \mathrm{~mm}$. $1989 \mathrm{E}(54 / 4 \mathrm{I})$.

LB930* Bodysherd from just below rim with at least six very fine thread-like horizontal opaque white marvered trails. Few bubbles. $12 \times$ i $3 \times 0.7 \mathrm{~mm}$. $1989 \mathrm{E}\left(5^{6}\right)$.

LB942 Bodysherd. $9 \times 8 \times 0.5 \mathrm{~mm} .1989 \mathrm{E}(7 \mathrm{o})$.

$L B_{1113^{*}} \quad$ Bodysherd with part of a vertical opaque white marvered trail. $14 \times 9 \times 0.7 \mathrm{~mm}$. 1989 $\mathrm{E}(74)$.

NPII O $^{*} \quad$ Bodysherd, just below rim, with five horizontal opaque white marvered trails. Fine metal, almost no bubbles. $22 \times_{\text {I I }} \times 0.7 \mathrm{~mm}$. D.c. $6 \mathrm{~cm}$. I $990 \mathrm{NPI} . \mathrm{CI}_{\text {I }}$ ( $)$.

Vessel I $I$ : Cone beaker with white vertical chevrons, pale yellow-green.

$L B_{346} \quad$ Base of cone beaker, with vertical opaque white marvered trail expanding towards the base. Few bubbles. Exterior abraded. I $3 \times 7 \mathrm{~mm}$, T. I.5-3 mm. D.c. $2 \mathrm{~cm}$. $1988 \mathrm{~B}(7)$.

LB754 Bodysherd with two vertical opaque white marvered trails. Few bubbles. $7 \times 8 \times 0.6 \mathrm{~mm}$. $1989 \mathrm{E}(4 \mathrm{I})$.

$N P_{I 476} \quad$ Bodysherd with decayed vertical opaque white marvered trail I $\mathrm{mm}$ wide. Few bubbles. $9 \times 6 \times 0.7 \mathrm{~mm}$. $1990 \mathrm{NP}$ I. $\mathrm{F}_{3}(2)$.

Vessel 12: ?Cup (cf. Vessel 2) with band of unmarvered spiral trails around base, and vertical ?chevrons above, colourless.

$L B 33^{*} \quad$ Bodysherd, surface has fine horizontal ridges and three horizontal spiral unmarvered

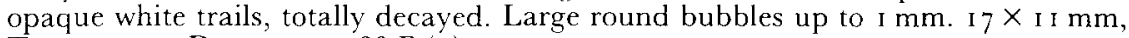
T. I-I.5 mm. D.c. $5 \mathrm{~cm}$. $1988 \mathrm{~B}(3)$. 
LBI243* Bodysherd with two vertical decayed opaque white marvered trails. Many bubbles. I $3 \times 7 \times 0.5 \mathrm{~mm}$. $1989 \mathrm{H}(2)$.

Vessel 13: ?Conc beaker with band of white trails below rim, colourless.

LB772 Bodysherd with eight horizontal opaque white marvered trails. Some bubbles. I $6 \times 8 \times 0.9 \mathrm{~mm}$. $1989 \mathrm{E}(4 \mathrm{r})$.

Vessel I4: Vessel of unknown form with vertical mould-blown ribs, very pale yellow. Such ribs are common on palm cups, but the sherds are too small to be sure of this attribution.

LB949 Bodysherd with vertical mould-blown ribs. Some bubbles, exterior worn. I $7 \times$ io $\mathrm{mm}$. T. 0.7-I. I mm. $1989 \mathrm{E}(72)$.

$\mathrm{NP}_{5} 506 \quad$ Bodysherd with vertical mould-blown rib $3 \mathrm{~mm}$ wide. Irridescent, rib full of circular bubbles. $8 \times 6 \times 0.3 \mathrm{~mm}$. I $990 \mathrm{NP}_{\mathrm{I}} \mathrm{G}_{4}(2)$.

Vessel 15: Vessel of unknown form, very thin walled, colourless.

LB819 Bodysherd. $13 \times 9 \times 0.4 \mathrm{~mm}$. $1989 \mathrm{~B}(29)$.

There are a further ten sherds which cannot be ascribed to particular vessels, six of which have opaque white trails. Two are slightly burnt.

$L_{703}$ Bodysherd, irregularly curved. Pale amber, few large bubbles. Surfaces very cloudy, possibly burnt. $18 \times$ i $2 \times 1 \mathrm{~mm}$. $1988 \mathrm{E}(3 / 26)$.

$N_{2} 6_{5} \quad$ Bodysherd with three horizontal opaque white trails, only partially marvered. Pale greenish yellow, bubble trails diagonal and vertical, round bubbles. I $8 \times 10 \times 0.4 \mathrm{~mm}$. D. c. $6 \mathrm{~cm}$. $1984 \mathrm{NP}_{3}$.vii (3).

NP620 Bodysherd with one thin opaque white marvered trail. Very pale yellow, abraded. $9 \times 8 \times 0.5 \mathrm{~mm}$, in two pieces. $\mathrm{I} 86 \mathrm{NP}_{4}(3)$.

NP7OI Bodysherd, one thin vertical opaque white marvered trail. ig $\times 7 \mathrm{~mm}$. I $986 \mathrm{NP}_{4}(3 \mathrm{a})$. On loan to Tenby Museum.

NPIoro $\quad$ Bodysherd with two horizontal opaque white marvered trails, one $0.7 \mathrm{~mm}$ wide.Pale yellow, few bubbles. $5 \times 4 \times 0.7 \mathrm{~mm}$. ${ }_{19} 86 \mathrm{NP}_{4}(3)$.

NPI343 Bodysherd from ?just below inturned rim. Pale yellow, few bubbles, abraded. $5 \times 13 \times 0.8 \mathrm{~mm}$. $1990 \mathrm{NPr} . \mathrm{Ci}(2)$.

NPI425 Bodysherd with one vertical opaque white partially marvered trail, widening, I-I.5 $\mathrm{mm}$ wide. Pale yellow, no bubbles. I I $\times 8 \mathrm{~mm}$. I $99^{\circ} \mathrm{NP}_{\mathrm{I}} \mathrm{F}_{4}(2)$.

$\mathrm{NP}_{1426}$ Bodysherd, partially melted, decayed. Yellow-green. i $\times 8 \times$ I mm. Ig9o NPI.F2sw (2).

NPI5I2 Bodysherd with two horizontal opaque white marvered trails, one $1.5 \mathrm{~mm}$ wide. Pale yellow. $9 \times 5 \times 0.8 \mathrm{~mm}$. i $990 \mathrm{NPr} . \mathrm{G}_{3}(2)$.

NPI545 Bodysherd. Very pale green, few bubbles, slightly decayed. $8 \times 7 \times 0.5 \mathrm{~mm}$. I990 NPI.B2 (2).

POSSIBLE IMPORTS

LB266 Bead, hexagonal cylinder, with ends bevelled irregularly. Circular central hole. Damaged, clear glass. ?Modern. $5 \times_{4} \times 4 \mathrm{~mm}$. $1988 \mathrm{~B}(3)$.

$L B_{313} \quad$ ?Base sherd. Pale green, outer surface with many bubbles. $20 \times$ I I $\times$ I.5 mm. I 988 $\mathrm{B}(3)$.

LB724 Bodysherd. Pale blue-green, few bubbles. $19 \times \mathrm{I}_{4} \times \mathrm{I}_{\mathrm{I}} 3 \mathrm{~mm}$. D.c. $6 \mathrm{~cm}$. Probably modern. $1989 \mathrm{E}(40)$.

$\angle B 8_{21} \quad$ Bodysherd with two vertical unmarvered self-coloured trails. Diagonal surface striations. Colourless. $14 \times 7 \times 0.6 \mathrm{~mm}$. Probably modern. 1989 B (28).

LBI239 Bodysherd with mould-blown beaded ribs. Pale green, frosted surface. $17 \times \mathbf{I} 3 \mathrm{~mm}$, T. $0.7-15 \mathrm{~mm}$. Possibly modern. $1989 \mathrm{H}(2)$.

$\mathrm{NP}_{1462^{*}} \quad$ Bodysherd from near ?base of ??funnel beaker or ?neck of phial. Lower part D.c. $2 \mathrm{~cm}$, expanding rapidly ? upwards. Greenish blue, metal fine, with vertical bubbles stopping suddenly at expansion point. i $\times 7 \times 0.5 \mathrm{~mm}$. I $990 \mathrm{NP}_{\mathrm{i}} \mathrm{F}_{4}(2)$. 
DISCUSSION OF THE GI.ASS

The glass vessels are mostly cone beakers or cups decorated with opaque white marvercd trails. Most of the vessels are in a metal of very fine quality, in very pale ycllow, yellow-green or colourless glass, with only the cup/funnel beaker Vessel 2 being a darker green colour. This type of assemblage is similar to that found on other Celtic sites, but there is a lack of bowls here. None of the material appears to be of Anglo-Saxon origin, or from the continental sources which supplied Anglo-Saxon England.

In comparison with the 30 or so other Insular sites the assemblage is similar in size to that of the Mote of Mark and is only exceeded in size by those of Dinas Powys, Cadbury Congresbury and Whithorn Priory. ${ }^{95}$ The provenance and date of these vessels is problematic. Harden dated the western Celtic examples to the 5 th to 6 th centuries, mainly on the basis that this is the date of the rare white-trailed vessels found in Anglo-Saxon graves. However this comparison is not valid as most of the types of vessel found on western sites differ from those in Anglo-Saxon contexts. The characteristic vessel of the Celtic West is a cone beaker decorated with opaque white marvered trails in vertical chevrons and in a band of thin horizontal trails below the rim (for example vessel numbers $4^{-1} 3$ below). No parallels to this form of decoration on cone beakers can be cited from Anglo-Saxon or continental sources. In addition both the colour and quality of the metal mark out the western vessels as being from a different source to the pagan Anglo-Saxon examples. Analysis of the white glass shows that a tin rather than antimony opacifier was used, though in some vessels the opacity is caused by bubbles (see below). The date of the western vessels can only be determined by stratigraphically associated material, which consists of the continental pottery imports, D and $\mathbf{E}$ ware. A mid-6th to early 7 th-century date can be suggested for much of the glass, especially that with chevron trails. ${ }^{96}$ This date is supported by the few distinctive pieces of glass of Anglo-Saxon origin found at Dinas Powys. ${ }^{97}$

The glass vessels can be summarized as follows:

I plain cone beaker, pale yellow (Vessel I)

I ?cup/funnel beaker, green with white trails (Vessel 2)

I colourless vessel with self-coloured trails (Vessel 3)

8 certain and 2 possible cone beakers with white chevron trails, various

shades of pale yellow or green (Vessels $4^{-1} 3$ )

I palm cup? with mould blown ribs (Vessel 14)

I vessel in very thin colourless metal (Vessel I 5 )

There are also a few dubious sherds which may be Victorian, including the possible neck of a phial or base of a funnel beaker, $N P_{1462}$. The cone beakers with chevron trails (Vessels 4-13) have been discussed above, but the preponderance of decorated vessels at Longbury Bank is unusual even for Celtic sites, as plain vessels are half as common as decorated vessels on other sites. ${ }^{98}$ Vessel 2 appears to be a small cup form which is difficult to parallel exactly. The base seems too narrow for a palm cup or bowl, but not narrow enough to be from a funnel beaker. It may belong to the intermediate series, which Ypey dates to the 8th century on the basis of Dutch finds. ${ }^{99}$ Similar vessels, though incomplete, are known from Saxon Hamwic. ${ }^{100}$ Vessel 2 differs from both the English and the Dutch examples in its decorative scheme. A tentative date in the $7^{\text {th }}$ or 8 th centuries can be suggested for this vessel. Vessel 3 is unique in the Celtic West in having self-coloured unmarvered trails in a zig-zag pattern. This type of decoration was possibly similar to the vertical chevrons seen on the cones (Vessels 4-13), but could be part of a more complex zig-zag pattern such as that found on some squat jars or an unusual cone beaker from Faversham, ${ }^{101}$ suggesting a possible 7 th-century date. Vessel I 4 may be a palm cup, but the only other example of this form in the Celtic areas is a recently discovered example from Whithorn Priory. A few sherds are distorted by heat but there is no sign of the fused glass found at Dinas Powys and other sites which might indicate the recycling of sherds for beads or inlays. The overall dates suggest a range from the later 6 th to 7 th or even 8th centuries. There is a notable lack of vessels with combed festoons, such as those found in 6th-century contexts at Whithorn Priory, or of the 5 th- to 6th-century Anglo-Saxon vessels such as those from Cadbury Congresbury, Dinas Powys and Whithorn. 
SCIENTIFIC ANALYSIS OF THE GLASS By JULIAN HENDERSON ${ }^{102}$

Chemical analysis of some of the Dark Age vessel glass from Longbury Bank was carried out in order to establish whether it conformed to other analyses of vessel glass of the period, or whether any distinct characteristics might help suggest its possible production source. Glass from two excavation campaigns, one by Dr Green and the other by Dr Lane and Dr Campbell, was analysed separately.

The technique of chemical analysis used was electron-probe microanalysis. This involved the removal of a minute (less than I mm long) glass sample from both the vessel body and where appropriate its decoration. Each sample was mounted in epoxy resin and polished till any weathering of the glass had been removed and a flat surface had been obtained. A detailed description of the analytical system and the conditions employed in its use have been published elsewhere. ${ }^{103}$ Standard glasses (of known composition) were analysed on a routine basis in order to check the accuracy of the analytical system. The relative analytical accuracy encountered for major components during these analyses (for a soda-lime-silica glass) were $4 \%$ for $\mathrm{Na}_{2} \mathrm{O}$ (sodium oxide), I $\%$ for $\mathrm{SiO}_{2}$ (silica), $3 \%$ for $\mathrm{K}_{2} \mathrm{O}$ (potassium oxide), $5 \%$ for $\mathrm{CaO}$ (calcium oxide) and $2 \%$ for $\mathrm{PbO}$ (lead oxide); for minor elements the relative analytical accuracy was $2 \%$ for $\mathrm{MgO}$ (magnesia), $\mathrm{I} \%$ for $\mathrm{Al}_{2} \mathrm{O}_{3}$ (aluminium oxide), $3 \%$ for $\mathrm{P}_{2} \mathrm{O}_{5}$ (phosphorus pentoxide), $10 \%$ for $\mathrm{Fe}_{2} \mathrm{O}_{3}$ (ferric oxide) and $\mathrm{CuO}$ (cupric oxide) and up to $20 \%$ for $\mathrm{Cl}$ (chlorine). Typical levels of detection are cited in Table 2.

\section{The samples}

Six samples of glass were analysed from Campbell and Lane's excavations, four from the body of the vessels (analyses 2, 3, 4, 5) and two from the decorative trails ( 1,6 ). A further ten samples were analysed from Green's excavations, all of which were body glass $(7-16)$.

\section{Results}

All of the first six glass samples analysed are of a well-defined compositional type with the two opaque glasses being somewhat distinct. The remaining ten samples are also distinct but are slightly different from the first six in composition. Although the two sets of analyses apply to a group of glass believed to be derived from a single phase of occupation of a building on Site E, the sherds from each set has had a different burial history. Those from Campbell and Lane's excavations are from heavily leached rendzina soils, while those from Green's excavations are believed to have been buried in organic rich midden material. However, differential weathering is unlikely to have caused the differences in composition between the two groups as in that case it would be difficult to account for the higher iron oxide values in the first set. All the glasses are of a soda-lime-silica composition, often described as being of a so-called 'Roman' type. However if the analytical data is examined more closely, apart from analysis no. 16 , it is evident that the magnesium oxide $(\mathrm{MgO})$ levels are consistently higher

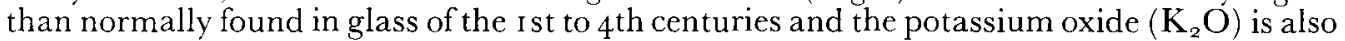
higher in analyses $1-6$ and $9-15$; typical magnesia and potassium oxide levels found in 'Roman' glasses are $0.5 \%$ for both, with the magnesia levels rarely exceeding I \%. As can be seen in Table 2 all the magnesia levels in analyses $\mathrm{I}-6$ fall between $1.4 \%$ and $1.7 \%$ and between $1.1 \%$ and $1.3 \%$ in the rest, apart from number 16 . The potassium oxide levels are between $0.8 \%$ and $\mathrm{I} .0 \%$ except in two analyses.

Another oxide in the first six glass samples which is somewhat higher than normally detected in so-called 'Roman' glass is aluminium oxide $\left(\mathrm{Al}_{2} \mathrm{O}_{3}\right)$. The levels detected here are (cxcepting number 3 ) between $2.8 \%$ and $3.2 \%$ whereas 'Roman' glasses tend to contain levels of $c .2 .5 \%$; indeed the levels detected in numbers 7 to 15 are more typical. Again number $\mathrm{i} 6$ is exceptional because it contains only $0.1 \%$ magnesia, a level usually only found in modern glass, and I. $2 \%$ aluminia, which is also more typical of much later glass. There is no doubt that this sherd is modern. 
The opaque glasses used for the trails are evidently rendered opaque by tin oxide $\left(\mathrm{SnO}_{2}\right)$ crystals reflected in the presence of $2.2 \%$ and $4.0 \%$ tin oxide respectively (see Table 2 , analyses $\mathrm{I}$ and 6 ), and further characterized by lead oxide ( $\mathrm{PbO}$ ) levels at $2.2 \%$ and $2.1 \%$ respectively. Neither lead nor tin oxides, were found in the other (translucent) glasses analysed. Tin oxide occurs naturally as cassiterite but is not normally associated with lead oxide. The analysis of small samples of 'opaque white' glass from the other vessels sampled did not provide any evidence for opacification and under the microscope masses of air bubbles were visible rather than crystals, so the technology is evidently quite different from that used in analyses $\mathrm{I}$ and 6 for the trails.

The colours of the translucent glasses are due to a combination of manganese $(\mathrm{MnO})$ and iron $\left(\mathrm{Fe}_{2} \mathrm{O}_{3}\right)$ oxides. Three out of the four glasses in the first six analyses contain quite high levels of both of these oxides, with analyses two and five containing $2.9 \%$ and $3.4 \%$ iron oxide respectively. It is interesting to note that high iron oxide levels provide another link between the technologies of the opaque white glasses and the translucent vessel glass - the opaque white glasses contain $3.2 \%$ and $3.1 \%$ ferric oxide. The level of iron oxide in the remaining ten analyses is also quite high, but is mainly higher in the first six.

\section{Archaeological implications}

The suggestion that fragments of glass form part of the same vessel can be tested by chemical analysis. It can be seen that sub-samples from the same sherd have very similar compositions except when one is decorative white (in which case one would expect lower silica and soda, but higher tin and lead) and the other a body fragment (Table 2, analyses I and 2). Taking the errors one encounters in the analysis of glass into account it is worth comparing the composition of individual fragments suggested as forming parts of identified vessels. Unlike analyses I and 2 there are differences between other pairs of analyses (Tables 2 , analyses 3 and 4 , and 5 and 6 ). The levels of calcium oxide $(\mathrm{CaO})$ in particular can be considered significantly different in both cases, though vessel 2 analyses are closer in many other respects (bearing in mind that one analysis is of opaque and the other for translucent glass) and the suggestion that they derive from the same vessel seems reasonable. The association of 793 and $L B 928$ as vessel i seems less likely. The other fragments $\left(N P_{704}, 706\right.$ and 2013; analyses 13,14 and I6) which have been suggested to derive from one vessel again provide difficulties. Analysis 16 is compositionally especially distinct and again the calcium levels are rather different between analyses 13 and I 4 .

In more global terms the relatively high magnesia and somewhat elevated potassium oxide levels in almost all the glasses analysed, together with relatively high aluminium oxide levels in all but number 3 of the first six, suggest that the glass is probably not pure recycled 'Roman' glass, but that it is at least modified 'Roman' glass, if not the product of separately fused batches of raw materials. The slightly elevated magnesia levels are present in all but the last analysis, the modern glass.

Since the unusual compositional characteristics are found in all the samples of the first six glasses analysed, it is worth stressing that the opaque glasses in analyses $\mathrm{I}$ and 6 were evidently made in the same compositional tradition as the translucent glasses which they decorated, with the opacifying agent (tin oxide) being added to a standard translucent glass. The 'white' glass used for the decoration of other vessel fragments analysed is of a significantly different composition and under the microscope it appears that masses of air bubbles cause the opacity rather than opacifying crystals. Certainly the chemical analyses of the 'opaque' glass samples in this instance did not reveal the presence of a possible component forming an opacifying compound.

The use of tin oxide as an opacifier in the white decorative glass of analysis numbers I and 6 is especially interesting. It used to be claimed that the use of tin oxide rather than antimony was a characteristic of early medieval glass. Turner and Rooksby suggested that tin oxide began to be used in glasses somewhere between the 2nd and 5 th centuries A.D. and that 'simultaneously antimony oxide ... was ceasing to be employed'. ${ }^{104}$ However many tin 


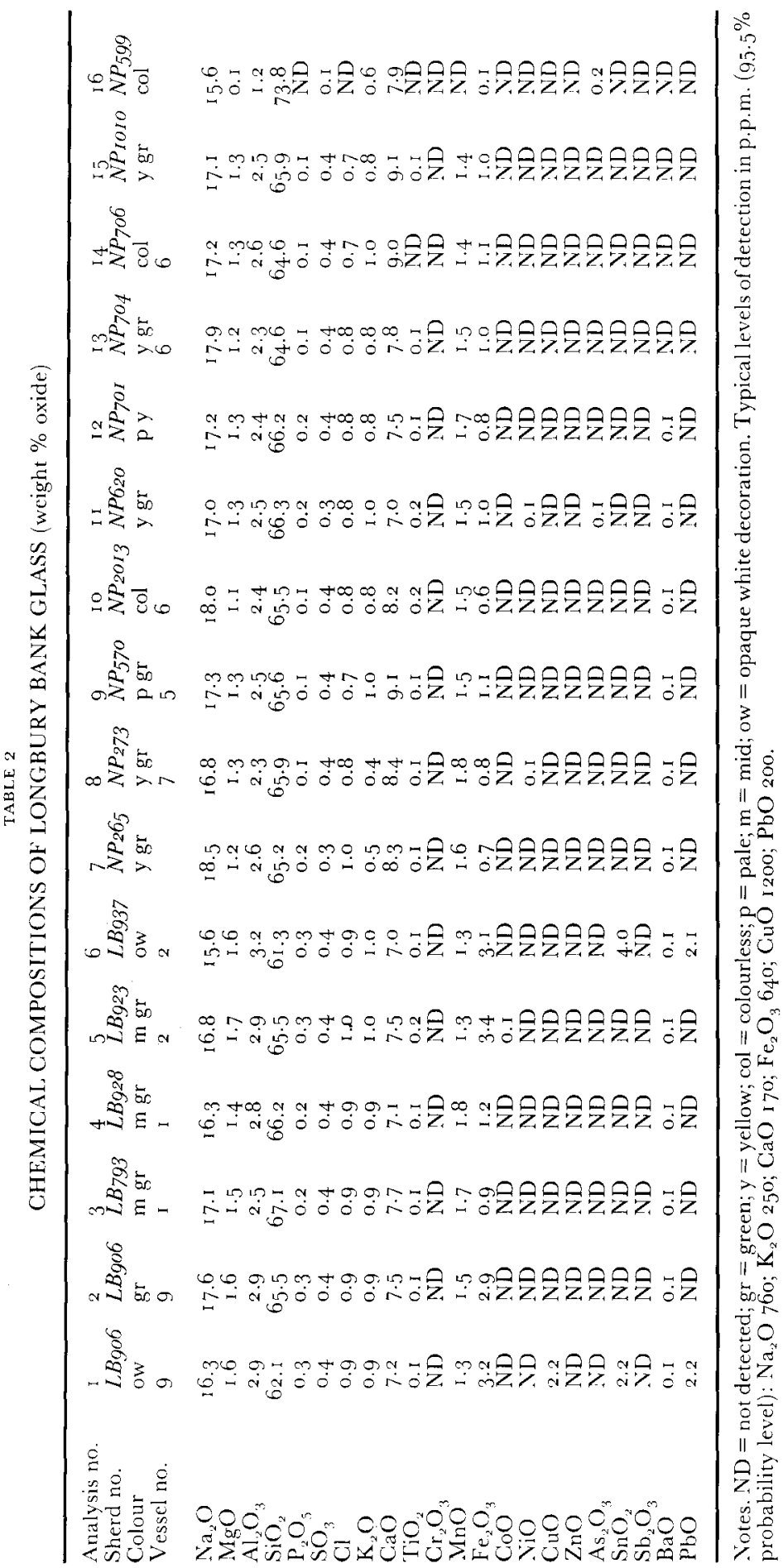


opacified glasses have in fact been discovered in 2 nd century в.c. contexts ${ }^{105}$ and there are many Viking-age antimony opacified glasses, so the picture is not as simple as originally put forward. ${ }^{106}$ Bimson found calcium antimonate in use in the 7 th-century opaque white glass used in the Sutton Hoo jewellery in contrast to the tin oxide used in the hanging bowl millefiori from the same site. ${ }^{107}$

In fact there are very few published modern analyses of the opacifiers used in early medieval white glasses apart from my own recent analytical work. This shows that the opaque white glasses used in the manufacture of Early Christian glass beads and millefiori rods found in Ireland only contain tin oxide and not calcium antimonate as an opacifier. ${ }^{108}$ In contrast nonc of some 40 analyses of opaque white glasses from 8th-century Åhus, Scania (southern Sweden) and Ribe (Jutland) are opacified with tin oxide. Although these Scandinavian white glasses were used for the manufacture of millefiori rods, multicoloured 'striped' rods, tesscrae, 'reticella' rods, and glass beads, only calcium antimonate appears to have been used as an opacifier. ${ }^{109}$

Unfortunately very little data is available for the composition of opaque white glass from Anglo-Saxon England and the Continent. Apart from the Sutton Hoo jewellery I am only aware of a single analysis of opaque white glass from the mid-Saxon Hamwic which indeed does indicate the use of tin oxide. ${ }^{110}$

In the absence of appropriate continental and Anglo-Saxon analyses it is difficult to interpret this evidence, though a technological distinction between the opacifying raw materials used in Scandinavia and those used in the glass from Longbury Bank and Irish sites is of some interest.

Although the consistent impurity patterns in all the Longbury Bank glass samples discussed here suggest the existence of an identifiable separate glass-melting tradition, many more glass analyses, particularly of continental glass, would be needed before this could be stated with any confidence. The evidence of the opaque white glass does however support the suggestion that an identifiable glass technology existed which was not wholly dependent on recycled Roman glass as is often tacitly assumed (the use of tin oxide is relatively unusual in the Roman world). In view of the typological suggestion of a continental origin, analysis of Frankish and Italian opaque white glasses would be desirable. The nature of the AngloSaxon opaque white glasses remains to be determined.

\section{MISCELLANEOUS GERAMIGS}

\section{Loom-weight} $\mathrm{E}(\mathrm{I} 8)$.

An annular loom-weight (Fig. 8) of fired clay was found in the early medieval feature

$L B_{5} 85 / 704^{*} \quad$ Two pieces of annular loom-weight. Hand-made, crudely formed. Section subrectangular. Fabric soft, orange-pink to dark grey, patchy. Abundant large organic inclusions of unchopped grass stems, burnt out, and occasional large lumps of sandstone and shale up to $10 \mathrm{~mm}$. Unabraded. Estimated D. $10 \mathrm{~cm}$, hole D. $3.5 \mathrm{~cm}$, section $30 \times 35 \mathrm{~mm}$. i $988 \mathrm{E}$ ( 18 ).

$L B_{777} \quad$ Irregular lump of fired clay with one curved surface. Possibly part of a loom-weight. L. $35 \mathrm{~mm}$. $1989 \mathrm{E}(43)$.

This form of loom-weight can be paralleled in Anglo-Saxon contexts, and would normally be taken as an indication of an Anglo-Saxon cultural milieu. Its presence on a typically British site requires explanation. Typologically the annular form of loom-weight is believed to belong to the early Saxon period, while after the 7 th century more bun-shaped forms developed. ${ }^{111}$ However annular loom-weights have been recognized in other contexts which do not appear to be Anglo-Saxon: at Dinas Powys; on the small Romano-British farmstead of Biglis, near Dinas Powys; in an early 5 th-century context in Gloucester; and from Henllys, Dyfed. ${ }^{12}$ It seems likely then either that this type of loom-weight was adopted at an early date by the British, or, perhaps more likely, that the type developed from the 

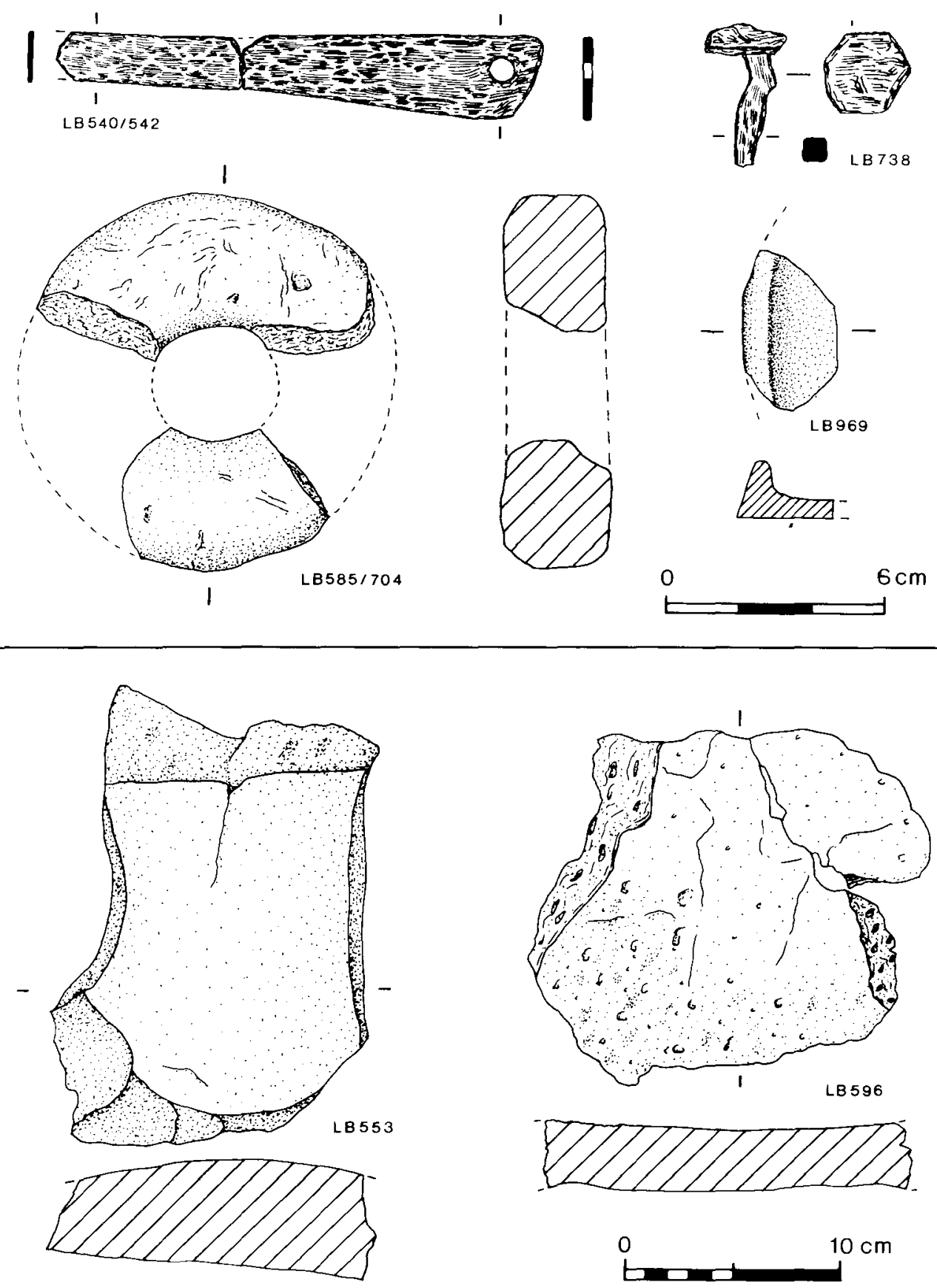

FIG. 8

Miscellancous finds. Iron: perforated blade, $L B_{5} 40 / 542$; rivet, $L B_{73} 8$. Ceramics: loomweight, $L B_{5} 8_{5} / 704$; heating tray, $L B 969$. Scale i:2. Stone: saddle quern, $L B_{553}$; rubbing slab, $L B_{596}$. Scale approx. 3 : Io 
Roman pyramidal shapes in both British and Anglo-Saxon areas. It may be significant therefore that the Biglis example is more of a cylinder than an annular ring. ${ }^{113}$ Whatever the derivation of the form it seems that the type can no longer be regarded as a cultural marker of Anglo-Saxon settlement.

Crucibles

$L_{152}$ Tiny sherd, exterior vitrified, quartz-rich fabric. I $4 \times 7 \times 2 \mathrm{~mm}$. ${ }_{9} 88 \mathrm{~A}(\mathrm{I})$.

$L B_{1} 6_{3} \quad$ Tiny sherd, $17 \times 16 \times 4 \mathrm{~mm}$. $1988 \mathrm{~A}$ (1).

$L B 969^{*} \quad$ Heating tray. Sherd of flat-bottomed shallow dish. Fabric hard not vitrified, olive grey. $43 \times 25 \mathrm{~mm}$. $1989 \mathrm{E}(76)$.

Only three fragments were recovered at Longbury Bank, unlike Dinas Powys which produced hundreds of crucible sherds. Two of these fragments are tiny and formless, but seem to come from small, thin-walled crucibles like the lidded pear-shaped crucibles at Dinas Powys. ${ }^{114}$ The third fragment (Fig. 8), LBg6g, is more distinctive, being part of a shallow flat-bottomed dish of a type generally referred to as a heating tray. Recently it has been suggested that some of these were parting vessels used for refining precious metals. ${ }^{115}$ This example does not have any of the characteristic features associated with this function, and indeed shows no signs of use.

\section{Vitrified furnace lining}

Twelve pieces of furnace lining were recovered, mainly from sites D and E. Most were small, but there were two larger pieces, one with fuel ash slag adhering. These point to some form of domestic or metalworking furnace at the W. end of the ridge.

\section{Fired clay}

Fifteen tiny scraps of unidentifiable fired clay were recovered which could derive from furnace lining, moulds, pottery or other categories.

\section{MEDIEVAL AND LATER FINDS}

Medieval, post-medieval and modern sherds of pottery and glass were scattered over the site in the topsoil, presumably derived from manuring. However a concentration of Igth-century glass and pottery at the $\mathrm{N}$. end of site $\mathrm{B}$ presumably represents picnicking, possibly associated with the excavation of the cave in $1877-78$.

\section{UTILISED STONE}

Flint implements, pebbles and waste flakes were scattered over the site, particularly in Trench $\mathrm{H}$. These will be described in the prehistoric report and none appear to be of early medieval date, either in terms of stratigraphic context or distribution. A dozen broken quartz crystal fragments, some from very large crystals, are scattered over the site though none are obviously worked. Leach reports that these are locally known as 'St David's diamonds' from their occurrence at St David's Head. ${ }^{116}$ These are certainly imports to the site, but whether they are of early medieval or prehistoric date cannot be ascertained.
$L B_{427}$
Large flat pebble, burnt, possibly a bakestone. $80 \times 70 \times 15 \mathrm{~mm}$. C (64).
$L B_{553} 3^{*}$
Broken? ?fire-cracked red sandstone. One surface convex
a saddle quern upper stone. $207 \times 145 \times 67 \mathrm{~mm}$. E ( 17 ).
$L B 59 I$
Fire-cracked pebbles and one smoothed slab, possibly a bakestone. $87 \times 60 \times 29 \mathrm{~mm}$. E (23).
$L B 594$
Flat angular slab of coarse sandstone with the edges of one flat face highly polished and slightly worn down. Not a saddle quern, used as a polishing block. $175 \times 133 \times 45 \mathrm{~mm}$. $\mathrm{E}(37)$. 
Slab of red marl with one flat face rubbed smooth in places. Used as a rubbing surface of some kind. $190 \times 85 \times 40 \mathrm{~mm}$. $\mathrm{E}(\mathrm{r} 7)$.

LB825 Fragment of a large flat rectangular pebble. Burnt. Possibly bakestonc. I $20 \times 95 \times 30 \mathrm{~mm}$. B $(31)$.

The large post-hole $\mathbf{E}(5)$ produced a number of stone objects from the backfill. $L_{553}$ appears to be the upper stone of a saddle quern. Whether this is a residual prehistoric item or an artefact in use in the early medieval period is difficult to ascertain. $L B 596$ is a flat slab of soft marl rubbed down in places indicating use as a smoothing surface of some kind. A small number of hammerstones and polishers in the topsoil could be of early medieval date, but there were single examples in the packing of the two prehistoric features $\mathrm{E}(4)$ and $\mathrm{H}\left({ }_{3} 6\right)$. Also in the former feature was a broken polished stone axe, probably of Prescelli dolerite.

\section{FERROLS METALWORKING DEBRIS}

Ferrous metalworking is represented by ore, slag, furnace lining and hammer scale. The ore is mainly a hydrated iron oxide, limonite/goethite. Many of the pieces are water-worn pebbles which probably occur naturally on the site, but there were marked concentrations; ${ }^{117}$ of a total of $9.5 \mathrm{~kg}$ over half came from Trench D with other significant concentrations in Trenches $\mathrm{C}$ and $\mathrm{E}$. The contexts which produced the ore are all natural bedrock hollows, and the ore was found at a lower level than any artefacts. One piece of ore was hematite, a much higher grade ferric oxide ore. This was found in E (6) and was possibly brought to the site for smelting, though there is no other evidence for smelting on the site.

The main evidence for iron working is provided by the iron slag, totalling over $6 \mathrm{~kg}$. The distribution of the slag is markedly concentrated on site $\mathrm{E}$, with lesser amounts in Trenches $\mathrm{C}$ and $\mathrm{D}$. The concentrations relate to specific features. $\mathrm{E}(5)$ produced almost $2 \mathrm{~kg}$ and $\mathrm{C}(7)$ over I $\mathrm{kg}$. The rest of the material came from topsoil in Trenches $\mathrm{E}$ and $\mathrm{D}$ and the red hill-wash in Trench $\mathrm{B}$. The slag itself is mainly from hearth bottoms $(98 \%)$ with small amounts of fuel ash slag scattered in the topsoil of Trenches B, C and E. The hearth bottoms include two fairly complete examples, $L B 600$ and $L B 639$, which have original diameters of $100-20 \mathrm{~mm}$. These are clearly from smithing hearths, both from their size and the inclusions of hammer scale. Further hammer scale was recovered from feature C (7). All the slag from the site seems to be from smithing activities, as is the case with most sites of the period, with no tap slag being recovered. ${ }^{\mathbf{1 1 8}}$

One piece of furnace lining from Trench $\mathrm{C}$ was fused to a lump of limestone bedrock, and although not in situ shows that a furnace or hearth was located nearby. Features $\mathrm{C}(7)$ and $\mathrm{E}(5)$ were filled with smithing hearth debris but as neither shows any sign of burning and the sunken situation does not correspond to known smithing hearths, which are usually raised for ease of working, it appears that neither was originally a hearth. The concentrations of material in these features seems to be the result of dumping of smithing debris from activities elsewhere on the site.

\section{MARINE MOLLLSCS}

The marine molluscan fauna consists almost entirely of shells of the European edible oyster (Ostrea edulis), with a few fragments each of cockles (Cardium sp.), mussels (Mytilus sp.), limpets and scallops. All of these can be found in tidal waters in the vicinity of Tenby. In the past oysters from the Tenby area were abundant. The oysters are concentrated in two fcatures in Trench E, E (5) with $39 \%$ of the total weight, E (6) with $18 \%$, and in the topsoil of Trench B with $33 \%$. The total amount of shell is not great $(3.5 \mathrm{~kg})$ and can only have represented a small addition to the diet of the inhabitants. The concentration in Trench $B$ could possibly be of Victorian origin, but the deposits in Trench $\mathrm{E}$ are indicative of early medieval middens. 
LAND MOLLUSGA $B y$ AMANDA ROUSE

A small quantity of land snails were recovered from among charred plant remains in flotation samples from contexts $\mathrm{E}(5)$ and $\mathrm{E}(6)$. The snail species present indicate a grassland environment, though probably not short-turved. Because of the paucity of the shells this is a very tentative conclusion. It is possible that the shells are modern contaminants from the present pasture.

\section{ANIMAL BONE By BARBARA NODDLE and JOHN EVANS}

The total quantity of bone from the site is very small (just over $2 \mathrm{~kg}$ ) and much of the bone is fragmentary and impossible to identify, due to the plough crosion and the lack of prescrved middens in the areas excavated. Of this material only the bone from the fill of contexts B ( I 7), B (2I), E (5) and $\mathrm{E}(6)$ can be considered to be certainly of early medicval date. Of these contexts only $\mathrm{E}(6)$ can be considered to be primary midden material.

The majority of the fragments were of cattle, with some pig and a little sheep, and deer (red deer or large roe) was rare. The size of the cattle is small, typical of other Dark Age assemblages. Only a few individuals could be aged, indicating that mature and immature beasts were present in the assemblage. Butchery marks and a number of split long bones point to the material being kitchen debris, but no estimate could be made of the relative proportions of types of joint consumed. All elements of the cattle skeleton were present, representing meat with high, medium and low food value. Some of the bone is burnt, usually only the occasional fragment, but a high proportion of that from B ( 19 ) is burnt, perhaps associated with the putative destruction of Structure A.

\section{CHARCOAL}

Two samples were taken for radiocarbon determinations, one from small twigs at the base of $\mathrm{E}(5)$, the large post-hole, and the other from the charred post in B (19), at the corner of Structure $\mathrm{A}$. The results are given below with dates calibrated at one and two standard deviations, with central dates in brackets. ${ }^{\mathbf{1 1 9}}$

TABLE 3

RADIOCARBON AGE DETERMINATIONS

\begin{tabular}{|c|c|c|c|c|c|}
\hline Context & Sample No. & Lab No. & Age B.P. \pm I $\sigma$ & Cal. A.D. \pm I $\sigma$ & Cal. A.D. \pm 20 \\
\hline $\begin{array}{l}B(19) \\
E(18)\end{array}$ & $\begin{array}{l}\mathrm{LB}_{393} \\
\mathrm{LB} 55^{\mathrm{I}} / 55^{2}\end{array}$ & $\begin{array}{l}\text { Beta-52349 } \\
\text { Beta-52350 }\end{array}$ & $\begin{array}{l}1510 \pm 60 \\
1560 \pm 70\end{array}$ & $\begin{array}{l}45^{0}(550) 610 \\
420(460-530) 590\end{array}$ & $\begin{array}{l}4^{10}(550) 650 \\
340(460-530) 640\end{array}$ \\
\hline
\end{tabular}

Both dates centre in the $5^{\text {th }}$ or 6 th centuries, with possible spreads from the $4^{\text {th }}$ to $7^{\text {th }}$ centuries, confirming the early medieval date of the structures on sites $\mathrm{E}$ and $\mathrm{B}$. Indeed the central date of the sample from Structure A, at A.D. 550, is almost exactly what would have been expected from the suggested date of the smashed amphora on the floor, though this may be coincidence given the strictures on the accuracy of radiocarbon dates. The determinations are close enough to each other to allow the possibility that they may belong to one phase of activity on the site.

\section{CHARRED PLANT REMAINS $B y$ ANNIE MII.LES}

Flotation samples were taken from the entire contents of features $\mathrm{E}(5)$ and $\mathrm{E}(6)$. Only a few charred grains were recovered, permitting only a qualitative account to be given. E (5) produced most of the grains, but the small total quantity suggests that the material is residual. The identifications show that barley and wheat are being consumed, and crop weed seeds from $\mathrm{E}(5)$ indicate some processing of the grain on the site. Although oats were 
identificd in the sample these were probably weeds of the crop. Fruit stones (Prunus sp.) indicate some collection of wild fruit.

\section{PHASING AND CHRONOLOGY}

Period o, the Palaeolithic phase, is not discussed here.

Period I, the Neolithic phase, was represented by two stake-holes $\mathrm{H}\left(3^{6}\right)$ and $\mathrm{E}(4)$, both of which had been packed with broken pottery, flints and stone implements. There was also a scatter of flints across all the excavated areas, particularly Trench $\mathrm{H}$, including scrapers, blades, an arrowhead, cores and waste flakes. Distribution and typology showed that almost none of this material was likely to be of Dark Age date. ${ }^{120}$ The pottery can be attributed to the Early Neolithic 'Abingdon' phase. ${ }^{121}$ Four ${ }^{14} \mathrm{C}$ accelerator dates were obtained from some of the human remains from the cave shaft, giving dates lying between 4600 and 4900 B.P., ${ }^{122}$ suggesting contemporaneity with the activity on the ridge. The penannular parch mark in the south of the field may be associated with this phase of activity. ${ }^{123}$

Period 2, the early medieval settlement phase, can be dated from the imported pottery and glass, the typology of the metalwork, and two radiocarbon dates. The earliest vessel is the Phocaean Red Slipware dish, $L B B_{20 I} / N C_{I}$, datable to $c$. A.D. 500 . The $B$ ware can be assigned to the later 5 th or first half of the 6 th century, the $\mathrm{D}$ ware to the 6 th century and the E ware and glass to the later 6th or first half of the 7 th century, though one glass vessel may be as late as the 8th century. The only distinctive piece of metalwork, the Type $\mathrm{G}$ brooch, has also been dated to the 7 th or 8 th century. The two radiocarbon dates centre on the 5 th $/ 6$ th centuries. The finds therefore indicate that this phase of occupation lasted for at least a century, and possibly as long as two centuries, in the period between the late $5^{\text {th }}$ and late $7^{\text {th }}$ century. The apparent lack of diagnostic artefacts in Wales for the 5 th century and the 8th to I Ith centuries precludes any certainty that the site was not occupied outside of this period.

Within this period there is some evidence of at least two sub-phases of activity. The deliberate back-filling of certain features, such as $\mathrm{C}$ ( 7 ) and $\mathrm{E}(5)$, in itself shows two phases, and may indicate levelling of the ground and re-planning of buildings. The burnt post in B ( 19$)$, and possibly in $\mathrm{E}(5)$, indicate destruction by fire and it could be inferred that these two events were linked. The smashed amphora in Structure A suggests a date for this putative destruction sometime in the first half of the 6 th century, and the radiocarbon evidence would not contradict this, but such a conclusion must be extremely tentative.

Period 4, the agricultural use of the field, is dated to the medieval and later periods by finds in the ploughsoil, presumably the result of manuring. The medieval

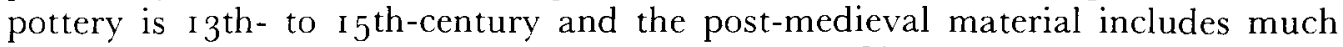
I 7 th-century North Devon ware, one i6th-century Cistercian-type ware base, an I 8th-century tin-glazed vessel and a large quantity of I gth-century wares from Trench B. This range suggests constant but sparse arable usage from the late medieval period to the present. Documentary evidence shows that the owner of 
Trefloyne was trying to enclose fields around $1600 .{ }^{124}$ The colluvial deposits in the valleys and scarp slopes may have resulted from intensification of arable activity coinciding with enclosure. The main destruction of the topsoil on the ridge may therefore date to the period betwcen $c$. I60o and the I 9 th century, by which time the field was fit only for pasture.

\section{DOCUMENTARY EVIDENCE}

There is no documentary material that can be related directly to the early medieval settlement, though place-name and charter evidence does allow some consideration of pre-Norman estates and their subsequent use.

\section{PLACE-NAME}

The etymology of the field name Longbury Bank (Longberry Backs $184 \mathrm{I}^{125}$ ) is of some interest even though it is not recorded before $\mathrm{I} 84 \mathrm{I}$. As with most place-names in this part of Pembrokeshire, it is of English origin and there is no record of an earlier Welsh name (but see below). The back element, ultimately from OE baec, 'back', is often used in the sense of a ridge or bank and is still current in this sense in some modern dialects. ${ }^{126}$ The plural presumably refers to the two steep sides of the ridge. The -berry/-bury element is of more interest as it could be derived from either OE burh, 'town or fort', or from OE beorg, 'hill or mound'. Both of these derivations are found in the place-names of S. Pembrokeshire and are represented, apparently indiscriminately, by the modern elements borough, burgh, bury, burrow and berry. ${ }^{127}$ Charles notes that although burh-derived names are rare in Wales, with only 2 I examples, the highest concentration is found in Pembrokeshire, where there are nine, at least two of which are associated with ancient fortified sites. ${ }^{128}$

It is therefore possible that the -berry/-bury element could preserve some memory that the site was an important occupied site in the past. Alternatively the name could be derived from beorg and merely be a topographical description, though this would make the back element somewhat tautological. Charles records only five beorgderived names in Wales, with three in Pembrokeshire, though there are ten examples of the plural form 'burrows', which locally means sandhills. ${ }^{129}$ The absence of medieval documentation for the name precludes any certainty.

\section{LLANDAFF CHARTER EVIDENCE}

The monastery (podum) of Penally (Pennalun, Aluni capitis) and its abbot (princeps) are mentioned in several Llandaff charters dated by Wendy Davies to the 7 th century, and it appears to have been an important establishment at that time. ${ }^{130}$ A series of estates (villae) in the Penally area are also mentioned in the charters, though these are either much later in date or are corrupt. ${ }^{131} \mathrm{~A}$ summary of these charters, using the charter numbers and published interpretations of Professor Davies, can be given as follows.

Charter i $25 \mathrm{~b}$ records that King Aergol (of Dyfed) gave the villae of Tref Carn, Laith ty Teliau and Menechi to Saint Teilo (and thus, by implication of its medieval 


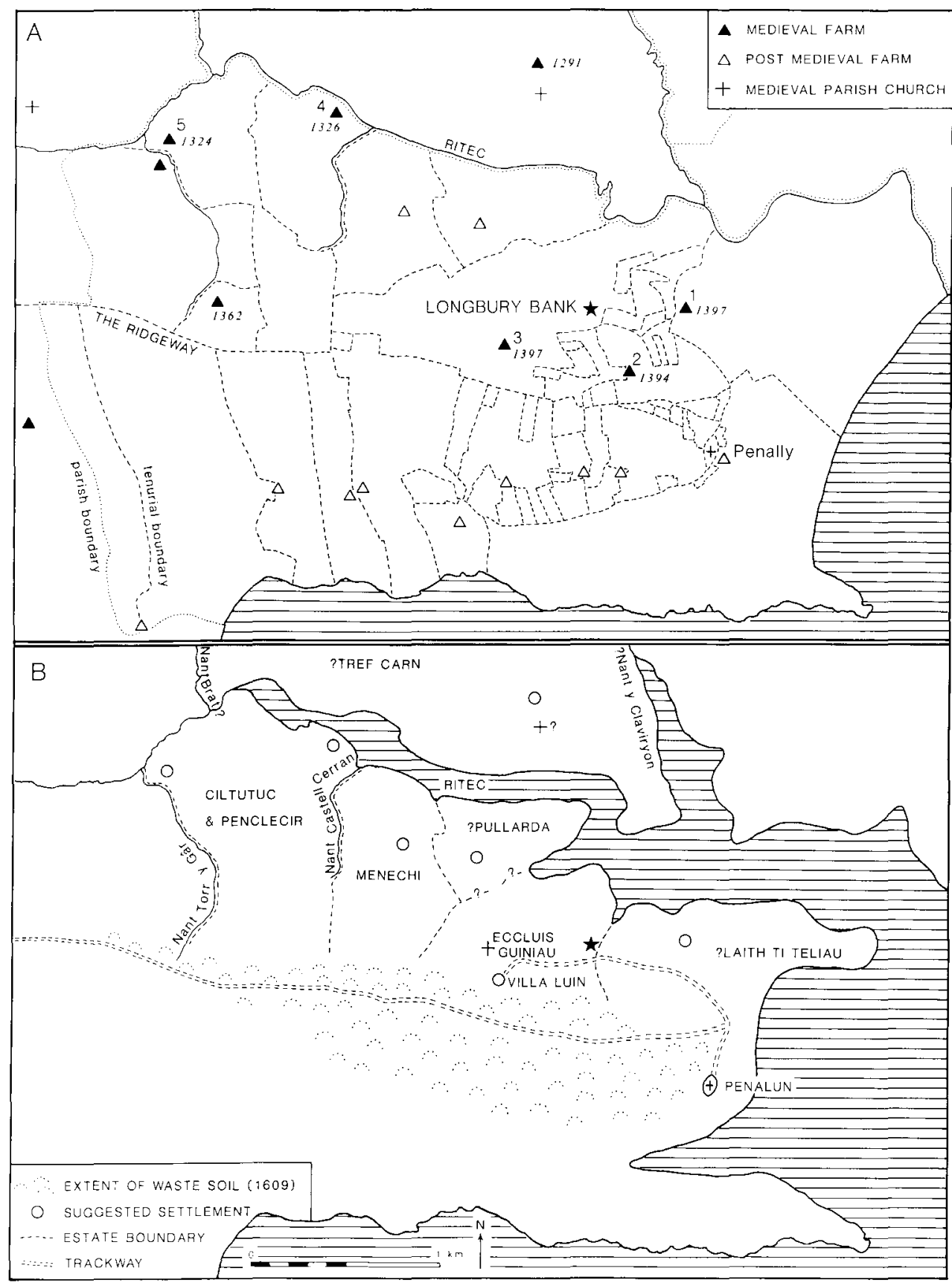

FIG. 9

A. Tenurial boundaries in Penally parish (from $184 \mathrm{I}$ Tithe Map Apportionment) showing first documented date of medieval farms. 1. Holloway; 2. Frankleston; 3 . Trefloyne; 4. Crasswell; 5. Tarr. B. Suggested pre-Norman estates and topography based on Llandaff charter bounds (see text for details) 
claims, to Llandaff), and the bounds of these are recorded in Welsh. ${ }^{132}$ Although this purports to be a charter of $c .500$, there is no reason to suppose that this is genuine, but it is valuable in giving the bounds of three cstates which are mentioned in genuine charters. Charter I 27 a records the gift of the villae of Ciltutuc and Penclecir by a certain Tudwg to Saint Teilo with the consent of King Aergol, and also gives the bounds in Welsh. Like I 25b it supposedly dates to $c .500$ but there is no evidence of an original charter. ${ }^{133}$ Charter 253 is a list of Teilo churches and territories confirmed to Bishop Joseph and Llandaff in $c$. I025. Although it has I 2 th-century interpolations Professor Davies considers that it derives from a note made under Joseph's episcopate. ${ }^{134}$ Under the cantref of Penfro (Pembroke) there is a list of properties which includes, in this order, Tref Carn, Laith ty Teliau, Menechi, Pull arda, Luin Teliau and Eccluis guinniau. Later in the list Ciltutuc and Penn clecir are mentioned. Although no bounds are given, Laith ty Teliau and Menechi are said to be on the banks of the Ritec and both are near Penally (iuxta penalun). Pull arda is said to be near Manorbier (iuxta mainaur pir), though this may be a mistake (see below). The six properties listed above, but excluding Ciltutuc and Penn clecir, are also mentioned in the same wording in a list of Teilo properties appended to another corrupt charter, number $123 .{ }^{135}$ Before discussing the nature of the charter evidence it will be shown that these estates can be localized fairly closely, enabling their relationship to the later medieval landholding pattern to be established (Fig. 9).

Identifications hinge on the fact that four of the estates are bounded on one side by the Ritec, which can be conclusively identified with the presently named Ritec lying to the N. of Longbury Bank. ${ }^{136}$ These estates are bounded on two other sides by minor streams or valleys which run into the Ritec, and the restricted number of these assists in the identification. In addition, two of the estates, Menechi and Ciltutuc with Penclecir, have a common boundary along one of these streams, nant castell cerran. Thus purely on internal evidence these estates can be located around the Ritec valley. Fortunately place-name evidence enables several of the estates to be localized more exactly and the position of the others to be inferred.

Most importantly, Luin Teliau, 'Teilo's grove', and Eccluis guinniau, 'the white church', can be equated with Trefloyne Farm and its neighbouring field of Castle Gwynne, 'the white castle'. ${ }^{137}$ Trefloyne is correctly in Welsh Trellwyn, 'the farmstead in the grove', presumably referring to its position surrounded by the woodland which still covers the steep N. face of the Ridgeway. There are no bounds for this estate, but it can be assumed to lie roughly within the bounds of the medieval and modern farm. The identification with Luin Teliau has been suggested in the past, and depends not just on the individual place-name elements but on the association of the two names both in the charters and on the ground. ${ }^{138}$ Eccluis guinniau is noted in charter 253 as the birthplace of St Teilo, an important 6th-century cleric who was associated with Penally in later medieval hagiography. ${ }^{139}$ There is no post-Conquest mention of a church or chapel which could be equated with eccluis guinniau and it must be assumed to have fallen into disuse after the Conquest, if it ever existed as an ecclesiastical site.

Nant torr i cair, one of the bounds of Ciltutuc with Penclecir, contains the element torr which, given the location by the Ritec, can be equated with the modern farm of 
Tarr. ${ }^{140}$ This identification is strengthened by the fact that Tarr and the neighbouring farm of Carswell are usually linked as one property in medieval documents. ${ }^{141}$ These two farms lie on a block of land bounded by two of the streams flowing into the Ritec, and can be equated with the Ciltutuc and Penclecir of the charters.

Tref Carn can possibly be equated with the farm of Carn Rock, sited by a large rock outcrop on the N. bank of the Ritec. One of the bounding streams of this estate, nant brat, may be the stream running into the Ritec by St Florence. ${ }^{142}$ Only one other stream flows from the N. into the Ritec, a branch of the Knighton Brook, which then has to be nant y claviryon. ${ }^{143}$ This block of land encloses the medieval parish church of Gumfreston, which could be a pre-Norman foundation. It may be significant that TrefCarn is noted in charter 253 as being villa tantum, sine ecclesia, perhaps suggesting that there was a church on this land but that it was excluded from this donation. This is the only villa so described in the list of 37 properties, though seven others are villa tantum. . $^{144}$

This leaves two estates unlocated. Laith ty teliau, unlike the other estates, has only one boundary, running from a carn baglan down the cil meinog to the Ritec. It is possible that this estate was the last in a series of estates along the banks of the Ritec, with the sea forming the other side of the estate. A triangular block of land, now part of Holloway Farm, lies here bounded by the dunes of Penally Burrows and the marshes of the Ritec. The cil meinog would then be the minor valley with a rivulet which runs down the S. side of Longbury Bank. Cil meinog, 'stony angle, back or recess', could well be a description of the craggy arête of Longbury Bank itself (cf. Longberry Backs). ${ }^{145}$ Menechi is bounded on one side by nant castell cerran, which is one boundary of Ciltutuc and penclecir, showing that these estates must be adjoining. This would place Menechi in the area of the modern farm of Robertswall, though the exact boundary between this and villa luin cannot be defined closely. ${ }^{146}$ Lastly, although pull arda is said to be located near Manorbier, there is some place-name evidence that it in fact occupied the site of the modern Penhoyle Farm, ${ }^{147}$ which would mean it occupied the correct place geographically in the charter 253 list.

Figure 9в shows the suggested layout of these estates. It can be seen that they form a coherent block of territory adjacent to the ancient monastery of Penally and occupying the N. half of the parish of Penally and the S. part of the parish of Gumfreston. Each farm or estate occupies a strip of countryside which covers three ecological zones: marshland, which could have been useful for water meadow, reeds and wildfowl; low-lying arable and pasture; and higher land of rough pasture and scrub, which could have been used for pigs or sheep. ${ }^{148}$ Davies has shown that the normal size of villae in the Llandaff charters is three modii (c. 125 acres) and it is interesting that the estates on the $\mathrm{S}$. bank of the Ritec are of this order of size. ${ }^{149}$ Tref Carn is apparently three or four times this size, though this area may include the church land of Gumfreston. This layout appears to be a coherent, even planned, pattern of settlement which the evidence of charter 253 would suggest was in existence by the early i ith century. It might be argued that the bounds of these estates are found in forged or corrupt charters which could date to the period of compilation of the Book of Llandaff in the early i 2 th century. ${ }^{150}$ This could be the 
case, but the bounds of estates are unlikely to have changed in a century, defined as they are by natural features which conveniently split the land into manageable units.

\section{POST-CONQUEST DOCUMENTATION}

Having established the late pre-Norman pattern of settlement in the area it remains to be seen how this relates to the medieval pattern. It should be noted however that the villae of the Llandaff charters refer to farm estates as a whole, so that we have no indication as to the actual sites of buildings occupied at this period. Figure 9A shows the known medieval farmsteads in the area with the date of the earliest documentation, and with approximate bounds as shown by landholdings in I $84 \mathrm{I}$ and early $\mathrm{I} 7$ th-century extents. ${ }^{151}$ It can be seen that each postulated

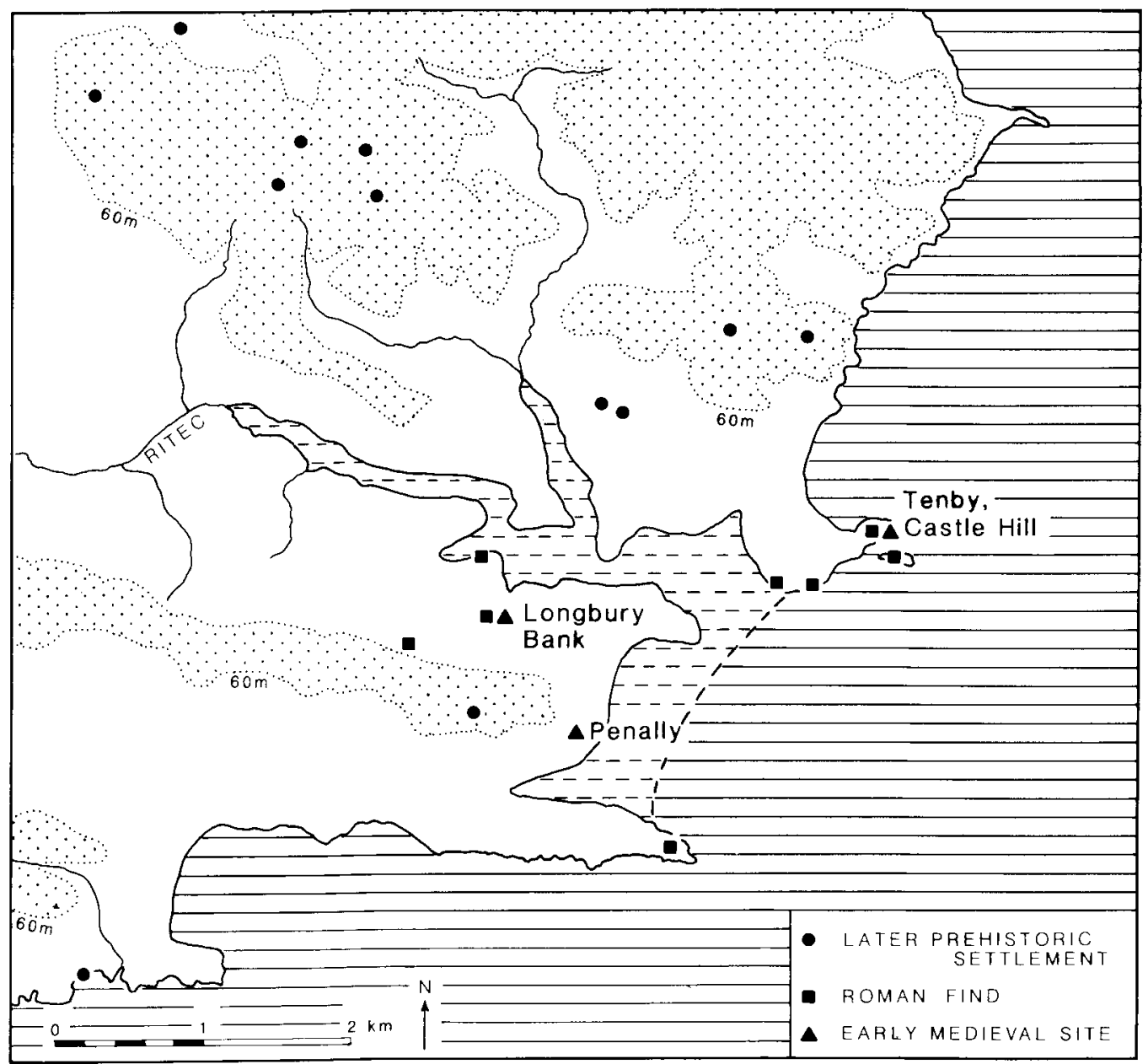

FIG. IO

Distribution of later prehistoric settlement (mainly from aerial photographs), Roman finds, early medicval sites, with former extent of Ritec inlet shown 
pre-Norman estate is occupied by one or two medieval farms and that the preNorman estates seem to have retained their form into the medieval period. Davies suggests that each villa of the charters of the standard three modii could have supported 30 to 4 o people, presumably occupying a number of dwellings. ${ }^{152}$ There may have been a central focus, perhaps occupied by a tenant. What little excavation evidence there is suggests that the earlier sites may not lie directly under the medieval farm building. ${ }^{153}$

The relationship between the pre-Norman and later landholdings in this area depends on the fate of the monastery at Penally. It has been noted that this monastery is documented in the 7 th century, and archaeological evidence in the form of four or five decorated stone crosses of the gth to roth centuries indicate that it was of considerable status in the immediate pre-Norman period. ${ }^{154}$ The monastery appears to have been dissolved at or by the time of the Norman conquest $c$. I I oo and none of the estates were church lands thereafter in spite of Llandaff's claims. ${ }^{155}$ Despite this, the later medieval history of these estates seems to betray their special origins. Howells, in his study of the evolution of field patterns in Pembrokeshire, independently notes that this group of farms was unusual in having freehold tenancies though the exact type of tenure is unknown. ${ }^{156}$ The irregular field patterns of these farms are noticeably different from those around St Florence, in Manorbier parish, and the S. of Penally parish. ${ }^{157}$

That these early medieval estates had belonged to the monastery at Penally can only be inferred. They were claimed in Liber Landavensis to belong to Llandaff, on the basis that they were Teilo properties, but this is clearly part of Llandaff's expansionist claims under Bishop Urban in the 12 th century. ${ }^{158}$ Penally was one of the three main centres associated, falsely or not, with Teilo by the I 2 th century, ${ }^{159}$ and their geographical proximity must strongly imply that the properties did belong to Penally in the pre-Norman period.

In conclusion, the documentary and topographic evidence suggests that the functioning landscape of the it th century was not radically disrupted by the Norman Conquest, though individual settlements may have been relocated. There is no indication of any high-status settlement in Penally parish that could be seen as a successor to the 6 th $/ 7$ th-century settlement at Longbury Bank. This in turn suggests there was a major shift in the location of at least the higher-status sites between the 8 th and I I th centuries. The evidence for the existence of a royal fort of the kings of Deheubarth (Dyfed) at Tenby by the Ioth century (Fig. Io) is based on an extensive description of the royal court in a Ioth-century poem, the Etmic Dynbych. ${ }^{160}$ This probably underlies the medieval castle site at Tenby but without excavation it is impossible to know if this is a new foundation of the later pre-Norman period or if it is located on the site of an earlier $5^{\text {th }} / 7^{\text {th-century defended royal residence. Its }}$ promontory location would not be unexpected in the latter case. It could be suggested that Tenby is a possible successor site to Longbury Bank, and that the former royal lands around Longbury Bank were given to the monastery at Penally after the shift in settlement to the new site. The splendid carved crosses at Penally could then be seen as a manifestation of this new wealth brought by the acquisition of these estates. 


\section{DISGUSSION}

The results of the excavations can be said to be both encouraging and disappointing. On the positive side was the identification of a major Dark Age western British settlement which produced a wide range of artefactual evidence and which appears to belong to a new class of undefended high-status secular sites. That the existence and precise location of the site was predicted from a detailed comparative study of the location of imported pottery on other sites of the period is encouraging for future identification of sites, but the lack of visibility of the site to normal methods of survey is alarming and might suggest that many more such sites have been overlooked in the past and will be difficult to locate in the future. However the positive results of the excavation mean that we can now be more confident in attributing stray finds of certain classes of material to settlement sites of the period, and an initial attempt to do this is made below.

More disappointing was the lack of structural evidence. Although this was due in part to severe plough erosion it may also be due to the nature of the regional building tradition in Wales at this period. A comparison with other early medieval and Late Roman sites located on limestone in $\mathrm{S}$. Wales reveals that all show a similar lack of coherent earth-fast features which enable building plans to be recovered. ${ }^{\mathbf{1 6 1}}$ The rock-cut drip gullies outlining two buildings at Dinas Powys remain the most convincing evidence in Wales for early medieval building plans, and the interpretation of these is open to a number of views. ${ }^{162} \mathrm{We}$ may have to become used to a lack of structural evidence in this region and redesign excavation strategies to recover the horizontal distributions of finds rather than concentrate on the normal concerns of vertical stratigraphy.

\section{FUNCTION OF THE SITE}

Despite the lack of structural evidence it is possible to describe the nature of the site and the activities carried on there. The settlement lay on a flat, sub-triangular area bounded by two steep craggy slopes but open on one side. The area occupied was small, with the focus of activity lying within an area of $c .30 \times$ I $2 \mathrm{~m}\left(0.03^{6}\right.$ hectare), with outlying activities over a larger area covering a maximum of o. I hectare. Although this area seems tiny for a high-status settlement, it is very similar to the internal area of Dinas Powys within its Bank I enclosure. Figure i I shows a comparison of the layout of the two sites, showing buildings, middens and the distribution of residual glass sherds within the occupation areas. ${ }^{163}$ It can be seen that both the area enclosed and the concentration of glass sherds is very similar, and it is possible that one or two buildings of the size of those at Dinas Powys could well have been located on the ridge at Longbury Bank. The distribution of glass sherds is of importance because it appears to represent material too small to be swept up from living areas, and thus gives a better indication of actual occupation areas than larger pottery fragments and other debris. ${ }^{164}$

The distribution of other material, mainly imported pottery sherds, is concentrated off the top of the ridge and down the N. slope in particular (Fig. I 2A). It can be assumed that, as at Dinas Powys, much of the midden material of the settlement was 


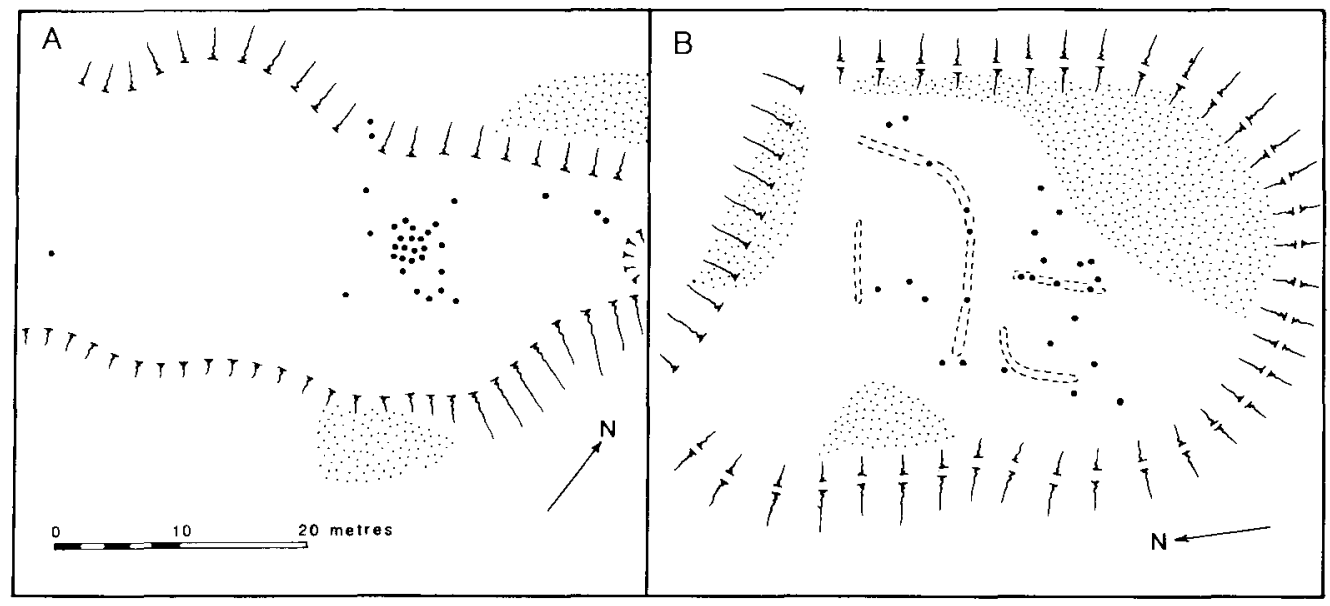

FIG. I I

Comparison of A. Longbury Bank and B. Dinas Powys at same scale showing distribution of glass sherds in occupation areas. Midden areas stippled

swept up and thrown over the edge of the slope, particularly to the leeward side of the ridge. The almost mutually exclusive distribution of glass and other material in Trench $\mathrm{E}$ is striking, and taken with the evidence from Dinas Powys that small glass sherds are concentrated within the area of buildings, suggests that a major building formerly occupied most of Trench E, and that almost all trace of the structure has been lost. If the glass sherds merely represented an area of midden deposits which were later ploughed out or otherwise removed, pottery and other finds would be expected amongst the glass.

The activities implied by the imported pottery and glass can be summarized as follows: the B ware amphorae were used for the importation of wine and olive oil; the Phocaean Red Slipware dishes, and the D ware mortarium and plate, were fine tablewares; the E ware vessels were containers for a variety of exotic commodities; and the glass vessels were used for drinking, probably imported wine. ${ }^{165}$ The association with exotic food and drink is clear, and the status of those people able to afford such foreign luxuries can be assumed to be high. Similar associations of imported pottery and glass with large buildings at South Cadbury, Dinas Powys and Cadbury Congresbury have been claimed to represent the archaeological remains of the Dark Age feasting halls so well known from the heroic literature of the period, and it can be suggested that a similar topos can be attributed to the more diffuse evidence from Longbury Bank. ${ }^{166}$

It is unfortunate that so little environmental evidence was recovered. The animal bone evidence does no more than show that cattle, pig and sheep were consumed on the site, perhaps with some hunted wild deer, while the charred plant remains show the consumption and possible processing of wheat and barley. None of this information is unexpected or exceptional for the period. The presence of oyster shell shows that locally collected oysters were a supplementary part of the diet. The lack of fishbones may be due to preservation factors. 


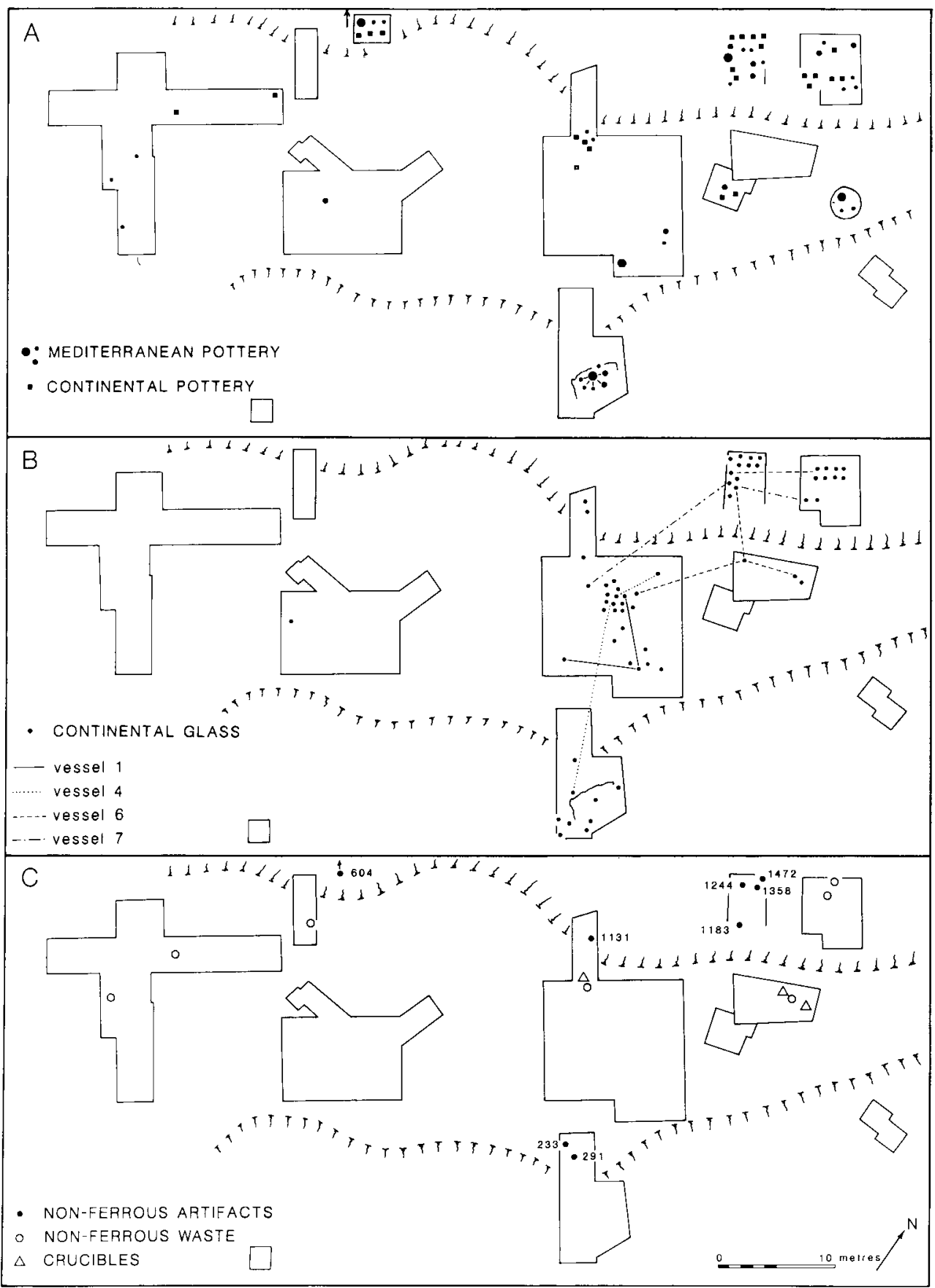

FIG. I 2

Distribution of early medicval finds. A. Imported pottery. B. Continental glass, with sherds from selected individual vessels. C. Non-ferrous metalwork (with finds numbers), metalworking waste and scrap, and crucibles 
Other clues as to the nature of activities on the site are given by some of the artefacts. The area of fine metalworking indicated by the crucible fragments, scrap metal and metal droplets is located along the N. edge of the site (Fig. 12C). A concentration of scrap on the $\mathrm{N}$. platform, with a few crucible fragments and a metal droplet in Trench A directly above, may be all that remains of a fine metalworking area located to the E. of the putative main building. The few scraps from Trenches $\mathrm{C}$ and $\mathrm{D}$ might suggest another possible focus some distance $\mathrm{W}$. of the living area. Analysis of the metal droplets shows that the source of the metal was not reused Roman scrap, as was commonly used in Anglo-Saxon copper alloys. ${ }^{167}$ Access to relatively pure copper and tin was most probably obtained through trade with SW. England. The fact that many brooches of the period are tinned on the surface also implies that tin was available in the Celtic areas. ${ }^{168}$ The piece of silver sheet from Trench D indicates that precious metals were also being worked on the site, and the purity of the silver suggests the vessel was imported, though it could have come from a Roman period vessel used as scrap. There is no direct evidence of glassworking from the site; a few sherds of burnt and distorted glass could be the result of accidental burning in a hearth rather than deliberate melting. Iron smithing was carried out, as it was on most sites of the period, but the distribution of the slag seems to be due to secondary dumping and cannot be used to indicate working areas. The clay loom-weight from Trench $\mathrm{E}$ shows weaving on a warp-weighted loom. A number of iron studs or rivets which came from Trench $\mathrm{E}$ are probably from domestic fittings such as doors or chests, which does not conflict with the interpretation of this area as having been occupied by a building. A few of the copper alloy objects are certainly scrap, chopped up for melting down in crucibles, but the penannular brooch $N P_{1472}$ is complete and must be a casual loss in the midden material by an inhabitant of the site. There is considerable evidence that the wearing of large elaborately decorated brooches was a sign of status in early medieval Celtic societies, at least by the 8 th $/ 9$ th centuries. ${ }^{169}$ Finds of brooches and brooch-making sites in Scotland, Ireland and elsewhere all seem to concentrate on high-status sites, often those with considerable quantities of imported pottery. One or two of the other copper alloy objects $\left(N P_{I 244}, L_{I I 3 I}\right)$ appear to be strap fittings of Germanic origin, similar to those from Dinas Powys. These could be seen as items traded, looted or exchanged, whether as scrap or complete items, from Anglo-Saxon England, though a continental origin cannot be ruled out. Further metallurgical analysis is required to help to resolve this problem and also the affinities of items such as the possible bracelet, $N P_{I I} 83$.

The settlement shows a number of characteristics which appear to be an indication of high status. These include the presence of significant quantities of imported pottery and glass vessels; evidence for fine metalworking; the use of precious metals; and a large penannular brooch. These features belong to a set of characteristics which define other high-status, often royal sites, in the Celtic West, though Longbury Bank differs from these in being undefended. ${ }^{170}$ There is tenuous evidence for at least one large timber building in Trench $\mathrm{E}$ with a small subsidiary hut, possibly a storehouse (Structure A), in Trench B, but no evidence for farm buildings or other structures which would imply that the site was the centre of a 
working estate on the model of a Roman villa. It is interesting that the same lack of ancillary structures was found at Dinas Powys. The evidence of the imported pottery and glass, concentrated around the site of the putative timber hall, suggests that feasting and drinking of wine took place there, with food served in imported tableware and drink in fine glass beakers. Meat and shellfish were consumed and hunting may have taken place. The picture evoked is of an aristocratic settlement, but it is necessary to look at other possible functions of the site, as an undefended high-status secular site would be unique in the Celtic West.

Firstly there is the possibility that this was a monastic or ecclesiastical site, some of which have produced small quantities of imported pottery or glass. ${ }^{171}$ The lack of defences might be cited in favour of this interpretation, and it could be argued that this might be the site of the Eccluis guinniau of the Llandaff charters mentioned above. One feature of the site mentioned in the interim reports was the crudely incised cross on the wall of the shaft of the cave which was apparently first noticed by McBurney in $1958 .{ }^{172}$ This was at such a height that it must have been buried under the fill of the shaft, indicating that it belonged either to the post-I 877 period or to before the shaft was filled in. It was originally considered that the fill of the shaft could be of early medieval date as sherds of Phocaean Red Slipware were found on the surface of the fill in $1877 .{ }^{173}$ Alcock had suggested that both skeletons and pottery might have fallen into the shaft when the roof of the cave collapsed, thus dumping remains from an early medieval cemetery into the cave below. However this explanation of the cave structure was rejected by geologists as extremely unlikely since the shaft is a sink-hole of considerable age. Recent dating of a series of human skeletons which were scattered through this 'black vegetable mould' fill of the shaft shows that most of the deposit must date to the Early Neolithic period. ${ }^{174}$ The cross must therefore be modern and may perhaps be an attempt by Rolleston's workmen to sanctify a site which was producing many human skeletons.

There is little evidence to support a monastic interpretation and much that can be argued against it. There is no evidence for a church, cemetery or monastic enclosure. Other negative evidence is more circumstantial, in that there are already two known monasteries of the 6th or 7 th centuries in the immediate neighbourhood, at Penally and Caldey (Fig. I3). ${ }^{175}$ To suggest that another contemporary establishment existed only one kilometre from Penally seems excessive. All of these points could be argued to be negative evidence, but as no positive evidence exists in favour of this interpretation of the site it must be regarded as most unlikely.

Alternatively, the site could have been a trading establishment, not on the scale of mid Saxon wic sites such as Hamwic, but what Hodges describes as a Type A emporium. ${ }^{176}$ The undefended low-lying location, the abundance of imported pottery and glass and the proximity to a sheltered estuary could all argue in favour of this interpretation. Given the lack of structural evidence for the settlement it is difficult to dismiss the theory and indeed it does not necessarily conflict with the interpretation as an aristocratic settlement. ${ }^{177}$ Some general arguments, however, mitigate against the idea that the site was primarily a trading place. Analysis of all the sites with imports in the Celtic West does reveal a set of possible trading places which can be distinguished by a lack of substantial defences, island location, lack of fine 
metalworking or precious metals and the use of $\mathrm{E}$ ware vessels as cooking pots rather than as containers. ${ }^{178}$ These sites include Dalkey Island and several on Scilly, and it has been suggested that Caldey Island may be the site of another. ${ }^{179}$ Longbury Bank differs from these sites in all respects except for its lack of defences and, if Caldey was a trading place, it would have been superfluous in this region. The likeliest explanation of the function of the site would therefore seem to be that it was indeed an undefended high-status settlement.

\section{COMPARISON WITH OTHER SITES}

It is possible that other undefended high-status sites may now be recognized. Linney Burrows, Pembrokeshire (Fig. I3), an eroding sand-dune site, has produced $\mathrm{E}$ ware and a number of pieces of metalwork of the period and could well be another settlement of Longbury Bank type. ${ }^{180}$ Recent environmental work on sand-dune sites in the area suggests that these were previously fertile high-quality grassland and prime areas for settlement. ${ }^{181}$ Other finds of metalwork of the period in coastal sand-dune sites may also therefore represent settlements of this type rather than being merely 'casual losses'. Kenfig Burrows, W. Glamorgan is one such site which has produced a stamped Type $\mathrm{H}$ brooch and two $4^{\text {th }} / 5^{\text {th }}$-century zoomorphic pins from near the buried medieval town. ${ }^{182}$ Twlc Point on the N. coast of the Gower peninsula has also produced a stray find of a Type $G$ penannular brooch with nearby occupation layers containing Roman pottery. ${ }^{83}$ Indeed there is a concentration of finds of early medieval metalwork all along the coast of S. Wales, which in itself suggests a concentration of wealthier settlement in the lowland coastal strip. ${ }^{184} \mathrm{It}$ is therefore possible that the Longbury Bank type of undefended high-status site could have been numerous in $\mathrm{S}$. Wales and perhaps elsewhere. The previously known concentration of sites on defended hilltops in S. Wales and SW. England may therefore be related to the greater visibility of these sites.

Analysis of the sites receiving imports in the $5^{\text {th }}$ to 7 th centuries suggests that two successive trading systems can be recognized in the Celtic West. ${ }^{185}$ The earlier, in the late $5^{\text {th }}$ to mid 6th century, seems to be a direct trade with the E. Mediterranean. For a fairly brief period, though longer than the handful of voyages recently suggested by Charles Thomas, Mediterranean traders sailed to SW. Britain. This trade focuses on SW. England and S. Wales and has only a minor continuation to the $\mathrm{N}$. into the Irish Sea. The most likely explanation is that metal sources underpin the trade - tin in Cornwall, lead and silver in the Mendips, and possibly lead and silver in S. Wales. Alternatively, the trade beyond Tintagel may represent the political/social links of the Dumnonian controllers of the tin trade, rather than direct links with the putative Mediterranean traders. In this context the idea of a Severn Sea zone may be important. The Severn Estuary and Bristol Channel serve to link S. Wales and Somerset, Devon and Cornwall. Tintagel is I $5 \mathrm{~km}$ from Longbury Bank, Dinas Powys is $30 \mathrm{~km}$ from Cadbury Congresbury and intervisible across the Severn. If the import distributions are taken at face value we have a Severn Sea zone running from Pembrokeshire to Glamorgan and then from Somerset to Cornwall. This could be a zone unified by sea access but also bound by a 


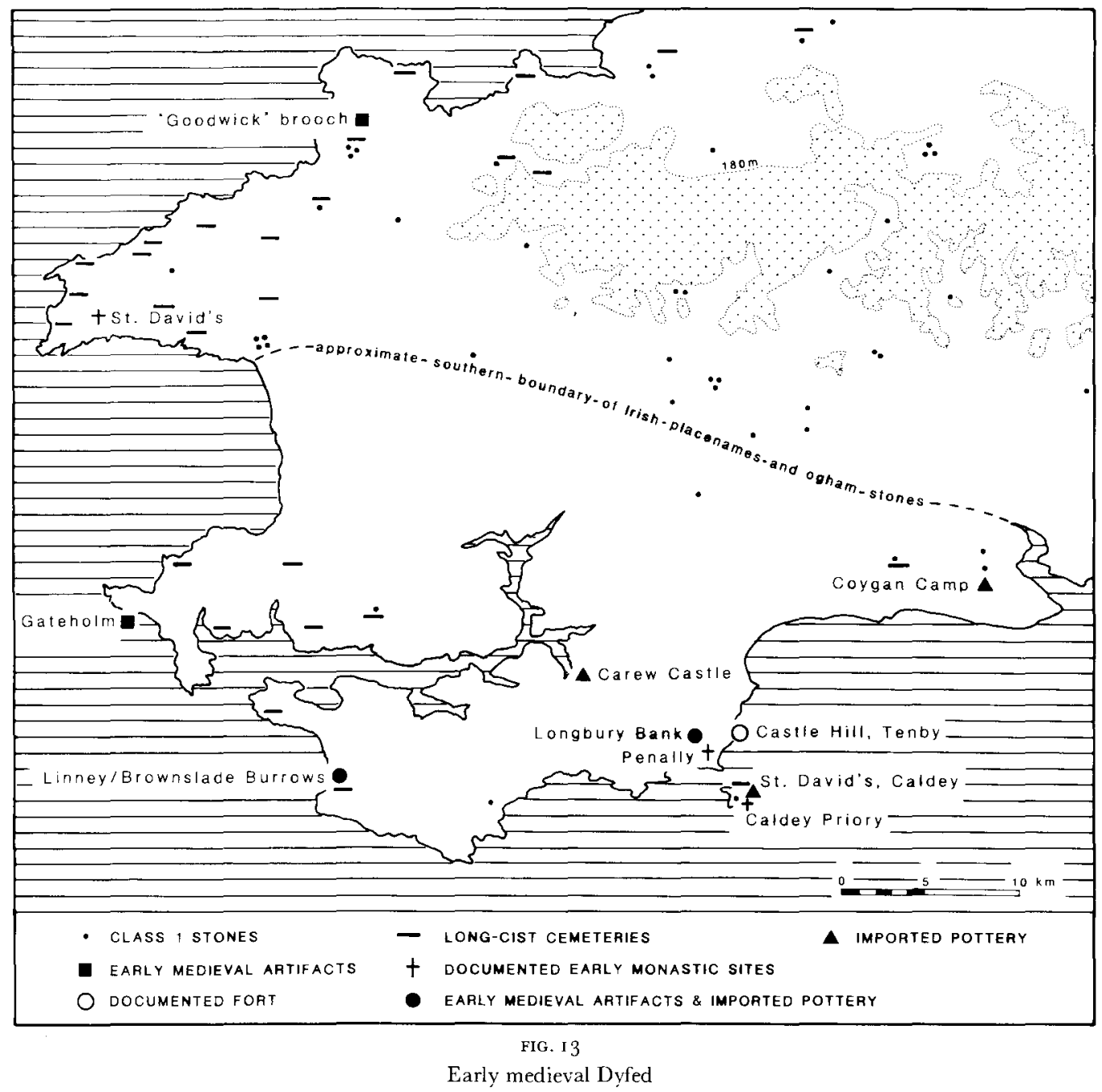

common utilization of imported goods in a system of status maintenance, possibly with overtones of Romanization. It is notable however that the imports do not penetrate upriver to Gloucestershire or Avon in spite of excavation on what might be regarded as appropriate sites. This Mediterranean trade to W. Britain seems to end in the mid 6th century, perhaps as a result of the reimposition of Byzantine control over the W. Mediterranean.

Subsequently, in the later 6th and 7 th centuries, a second trading system characterized by $\mathrm{D}$ ware, $\mathrm{E}$ ware and imported glass can be postulated involving trade between W. France and the Irish Sea zone. In this trade, SW. England is excluded, perhaps because of the imposition of English political control on Somerset, Dorset and parts of Devon. Limited finds reach Cornwall, but S. Wales seems 
integrated into a trade that focuses further N., on the lands around the Irish Sea, with considerable quantities of pottery reaching Ireland and Scotland.

Evaluation of the import ware assemblages throughout W. Britain would suggest that some sites were major points of importation and that distribution from those centres was secondary and small scale. In the $5^{\text {th }}$ and 6 th centuries within the Severn Sea zone, Tintagel stands out as the largest centre but Cadbury Congresbury and Dinas Powys also may be centres of importation. South Cadbury, though inland, has an assemblage appropriate to an import point or controller of importation. All these major sites are defended and on the basis of their other features seem likely to be high-status aristocratic or royal sites.

A few other sites or areas could be specialist trading locations as they lack characteristics of the putative royal sites. Dalkey Island is the best example of this an offshore island which could have been used as a neutral or secure trading site as in Hodges' model of ports of trade. Caldey off the S. Wales coast could also be such a site.

The location of Longbury Bank is very similar to that of Gwithian in Cornwall, a classic but as yet unpublished site, where quantities of imports are found associated with a group of small stone-walled huts. ${ }^{186}$ At Bantham and Mothecombe in Devon eroding sand sites have produced imported pottery as well as other evidence for early medieval settlement.

The function of these coastal sites is problematic, but their location makes it possible that they are connected in some way with trade. Charles Thomas has suggested that Gwithian was 'not socially higher than a farm of a tin-stream contractor', obtaining its imported pottery by 'diffusion' from a nearby unlocated power centre. ${ }^{187}$ However given the restricted excavation at Gwithian, it is possible that more substantial structures, appropriate to a more aristocratic milieu, once existed or still exist nearby. Whatever the status and function of these sites, their concentration on the coast is presumably due to a refocusing of trade in the early post-Roman period concomitant with the breakdown of the Roman road transport system of distribution. The control of access, firstly to Mediterranean traders and later to continental trade, would entail a coastal location.

The undefended non-island sites such as Gwithian, Bantham or Longbury Bank may possibly have been trading foci under royal control, the western equivalents of the later English wics, but on a much smaller scale. The use of imported luxuries on sites such as Longbury Bank suggests that these sites may have been higher up the social scale than Thomas credits, and the flimsy nature of the surviving evidence for structures may indicate that they were temporary summer camps of royal officials concerned with the control of trade. However in contrast to this view there clearly are ancient settlements in modern sand-dune areas which are merely settlement sites of not negligible status. Sites like the Udal in the Hebrides or Buckquoy in Orkney have nothing to indicate they are other than normal permanent settlements, ${ }^{188}$ and Gwithian and Longbury Bank could be as well. Here comparisons of Longbury Bank with Dinas Powys are striking, both in the range and nature of the finds, and in the vestigial nature of the structures. Only the preservation of middens and the provision of defences mark Dinas Powys out. 
If Longbury Bank is an undefended high-status settlement, and not unique except in its chance discovery, we could suggest the existence of other undefended estate centres, perhaps royal residences of the type postulated by Alcock for N. Britain. ${ }^{189}$ In this case small peripatetic courts might utilize estate centres for part of the year while using more important defended sites when required to by the social calendar or the exigencies of warfare.

If we envisage a relationship between undefended sites such as Longbury Bank and defended royal residences we must consider the locations of these putative defended sites (Fig. I3). Tenby is the first obvious location - a craggy coastal promontory I $\mathrm{km}$ from Longbury Bank, with Roman period finds and documentary evidence for a $\mathrm{I}$ oth-century royal site. If Longbury Bank is not a royal residence then Tenby's castle site may conceal a 5 th/6th-century fort. Alternatively Coygan Camp, a reused Iron Age hillfort with the richest Late Roman period 'native' occupation in SW. Wales, has evidence of imports and metalworking. Unfortunately this site was destroyed without full investigation but its location on another craggy promontory must make it a strong contender for a royal residence $20 \mathrm{~km} \mathrm{E}$. of Longbury Bank. Finally Carew Castle, $8 \mathrm{~km}$ to the W., which is as yet only slightly explored, has multivallate ramparts, 7 th-century ceramics, and an early i th-century cross erected by one of the kings of Deheubarth, and might be another possible contender for a major contemporary site.

\section{SETTLEMENT HISTORY}

It is difficult to discuss the history of antecedent settlement patterns in this part of Pembrokeshire because of the lack of excavation evidence from the Iron Age and Roman periods. Figure io shows the known distribution of putative sites of these periods, based mainly on aerial photographs of cropmark sites believed to be of Iron Age date, and stray finds of Roman artefacts, mainly from cave sites. ${ }^{190}$ Comparison with Figure 9B, which shows the early medieval settlements identified from charter evidence, reveals an almost mutually exclusive distribution. This could suggest that the mainly low-lying limestone areas known to have been occupied in the early medieval period were newly assarted from waste or woodland, as would the derivation of the Trefloyne place-name. Alternatively it could be due to bias in the aerial photograph evidence, with soil and geological conditions favouring the recognition of sites in non-limestone areas, though the recognition of the possible prehistoric penannular ditch on the aerial photograph of Longbury Bank mitigates against this.

The close relationship of the early medieval estates to the post-Conquest settlement pattern in the immediate vicinity of Longbury Bank has been noted, but it is also important to look at how Longbury Bank fits into the wider pattern of known early medieval settlement in Pembrokeshire (Fig. I3). Our knowledge of early medieval sites in the area has increased dramatically in the last few years with the identification of a settlement with imported pottery and undated multiple defences at Carew Castle, stray finds of imported pottery from a possible trading site on Caldey Island, and the excavation of Longbury Bank itself in addition to the previously known site of Coygan Camp. ${ }^{191}$ Recent work has also led to the 
recognition of imported $\mathrm{E}$ ware from Linney Burrows, which along with finds of a penannular brooch, two copper alloy pins (one double-spiral headed), a blue glass bead necklace and an early medieval bone comb from the same sand-dune area indicate the presence of another major settlement. ${ }^{192}$ Furthermore, Heather James has recently collated information on the long-cist cemeteries of the area which appear to be characteristically early medieval in date and give an indication of areas of settlement. ${ }^{193}$ As already mentioned there is documentary evidence for a major royal fort on the headland under Tenby Castle in the 9 th/ 1 oth centuries. ${ }^{194}$ The enigmatic site of Gateholm was also probably occupied in the early part of this period as indicated by an Irish type of pin. ${ }^{195}$ The distribution of Nash-Williams' Class I inscribed Early Christian monuments also gives a pointer to the general settlement pattern in the pre 9 th-century period. ${ }^{196}$ Taking this scattered, though for Wales exceptional, evidence together it is possible to make a tentative interpretation of early medieval settlement in Pembrokeshire.

It is noticeable that the sites with imported pottery are confined to the S. coastal part of Pembrokeshire which has the better land and which falls outside of the primary areas of Irish settlement as shown by place-name evidence and ogham inscriptions. As far as we know both S. Pembrokeshire and the more northerly zone of Irish influence were part of one kingdom. Yet the two archaeological distributions of imports and ogham/place-names are almost entirely separate. Although the absence of imports from the northerly zone may be a chance factor of discovery we should note the absence of any import ware finds from the recently excavated sites of Brawdy and Castell Henllys. ${ }^{197}$ Clearly the recognition and excavation of probable high-status sites within the Irish zone would be desirable to confirm whether these distributions are genuinely separate, but we may legitimately hypothesize the existence of two distinct cultural traditions within the kingdom of Dyfed.

The import sites are either on islands or close to former or present estuaries, in low-lying situations. Otherwise, however, they are a heterogeneous assemblage of site types. Coygan Camp is an Iron Age hillfort reoccupied in the Roman period and possibly with continuous occupation through till the 6th century within dilapidated defences. ${ }^{198}$ Longbury Bank appears to be an undefended site though in a defensible location. Caldey Island may be an undefended trading site or an ecclesiastical site. The settlement type at Linney Burrows is unknown, but appears to be undefended, though there is a triple-ramparted fort nearby. ${ }^{199}$ Carew Castle has multiple banks and ditches, some of which may be of early medieval date. This pattern, with three out of five sites undefended, is in contrast to other sites with imported pottery in S. Wales and Somerset which are almost all on well-defended sites. ${ }^{200}$

A shared characteristic of these $W$. Welsh sites is that, as with the handful of Romano-British sherds from Longbury Bank, most sites have some indication of Roman period activity on or close to them (cf. Fig. Io). Coygan Camp had an important Late Roman occupation which, according to a survey of sites of the period, has exceptional material remains for this area. ${ }^{201}$ Carew Castle has a large quantity of Roman pottery. ${ }^{202}$ Caldey Island has several cave sites with Roman pottery, and a cremation in a glass vessel with coins. ${ }^{203}$ Several distinct finds of Roman coins and other material from Tenby itself suggest that this site was 
important in the Roman period. ${ }^{204}$ Near Longbury Bank Romano-British pottery was discovered at Hoyle's Mouth cave and 4 th-century coins are recorded 'at Trefloyne'. 205 Gateholm has considerable amounts of Late Roman pottery, and some of the structures may date to this period. ${ }^{206}$ There are no recorded Roman finds from Linney Burrows unless the missing necklace of blue beads mentioned above is from a Roman period burial, though what may be Roman period pottery is recorded from the adjacent Buliber Camp. ${ }^{207}$ This evidence has to be interpreted cautiously, as recent work on the Roman material from Dinas Powys has confirmed Alcock's original conclusion that these artefacts were brought to the site in the post-Roman period, and the same probably applies to the Roman pottery from the newly discovered early medieval fort site of Hen Gastell, W. Glamorgan. ${ }^{208}$ However most of the high-status defended sites of the early medieval period in Wales have produced evidence of Late Roman (i.e. late $4^{\text {th }}$ century) occupation: namely Degannwy, Dinas Emrys, Dinorben and Coygan Camp. ${ }^{209}$ It seems that the withdrawal of the Roman army and bureaucracy in the early $5^{\text {th }}$ century did not immediately lead to major settlement changes, except perhaps in the extensively Romanized SE. of Wales. This pattern of continued or recurrent use also seems to apply to lower-status sites as there is now some evidence of continuing post-Roman usage of small farmsteads such as Drim in Pembrokeshire and Ty Mawr and Graeanog in N. Wales. ${ }^{210}$ This latter evidence is based largely on radiocarbon dates and very insubstantial structural remains as there are no diagnostic artefacts of the period apart from the imports. Not all Romano-British settlements continued into the early medieval period, but some did despite the apparently drastic change in nonperishable material culture.

Early medieval settlements in Pembrokeshire were widespread but the higherstatus sites had coastal locations. Some of these, such as Longbury Bank, appear to have been located on previously unoccupied sites, while others, such as Coygan Camp, show continuity from the Late Roman period. These major coastal sites can be seen as a response to, and an attempt to control, the availability of imported luxury goods from the late 5 th century. Both 'traditional' sites such as Coygan Camp or Carew Castle as well as new sites like Longbury Bank were sited near good harbours or overlooking estuaries, thereby controlling communication and the flow of goods to the interior. With the demise of the import systems in the later 7 th century these sites may have lost their rationale and few seem to continue into the 8 th century. Some fort sites may have been re-occupied in response to specific threats: Degannwy was burnt in A.D. 822 by the Mercians, and perhaps Tenby's occupation in the Ioth century, if it was not continuously occupied from the 5 th century, was in response to Viking raids. ${ }^{211}$

The evidence from Longbury Bank has been interpreted to suggest a shift in high-status settlement sometime between the 8 th and Ioth centuries. From the immediately pre-Norman period onwards the dispersed settlement pattern of the rural areas seems to have remained basically static apart from the intrusion and growth of town lands and the varying fortunes of church property. The preindustrial pattern of dispersed settlement has remained basically unchanged since the late pre-Conquest period here, as in other parts of the Celtic West. ${ }^{212}$ 


\section{ACKNOWLEDGEMENTS}

The excavation was carried out by staff and students from the Department of Archacology, University College Cardiff (now UWCG) with funds from UC Cardiff, the Board of Celtic Studics of the University of Wales, and the National Museum of Wales. We are grateful to the two owners of the site, University College, Aberystwyth and F. H. Gilman and Sons, for allowing excavation to take place and in particular to $\mathrm{Mr} \mathrm{F}$. E. Gilman for considerable help and flexibility over accommodation. We would also like to thank Michael Caulfield and the conservation staff of the NMW for assistance and equipment; the Dyfed Archacological Trust for invaluable equipment and site caravans, and access to their SMR; MrJohn E. Tipton of Tenby Museum for local help and access to the collections; Gwyn Jones of Trefloyne Farm for considerable co-operation; Andrew David for the initial geophysical survey; Sandy Gerrard for permission to publish the E ware from Carew Castle in advance of the excavation report; Michael Hamilton for the UWCC resistivity work; Stephen AldhouseGreen for providing assistance and access to finds and information from his own excavations at Little Hoyle. Help was also provided by Heather James and Terry James of DAT; Elizabeth Walker and Mark Redknap of NMW; John Morgan, Howard Mason and Viola Dias of UWCC. Assistance with specialist reports was given by Annie Milles, John G. Evans, Stephen Greep, Julian Henderson, Carl Heron, Robert Jones, Barbara Noddle, Peter Northover, Amanda Rouse, Leslie Zienkiewicz, and various staff of the British Museum. Figure 5 was drawn by Jaqueline Pearce of the National Museum of Wales, Figures $6-8$ by E. Campbell, and the others by H. Mason. Plate I is courtesy of Dyfed Archaeological Trust and Plates II, B and II, C are from the National Museum of Wales. Finally we must thank the editor for his assistance in preparing the final text.

\section{NOTES}

${ }^{1}$ School of History and Archaeology, University of Wales, College of Cardiff, P.O. Box gog, Cardiff CF I 3 XU.

2 At the time excavation commenced the estate was in the possession of University College, Aberystwyth, but in I 989 the estate was sold to F. H. Gilman and Sons, Stamford, Lincolnshire.

3 The various excavations of the Little Hoyle are summarized in H. S. Green, 'Excavations at Little Hoyle (Longbury Bank) in $19^{84}$ ', in D. A. Roe (ed.), Studies in the Upper Palaeolithic of Britain and North-West Europe (British Archaeological Reports S296, 1986), 99-I I9, and will not be repeated here. The National Museum has also excavated in seasons 1986 and I 990 .

${ }^{4}$ L. Alcock, 'Post-Roman sherds from Longbury Bank Cave, Penally (Pembs.)', Bull. Board Celtic Stud. I 8 (1958), 77-79; C. A. R. Radford, 'Imported pottery found at Tintagel, Cornwall', in D. B. Harden (ed.), Dark Age Britain (London, 1956), 59-70.

5 Alcock, op. cit. in note 4, 78 note 6; L. Alcock, 'Pottery and settlement in Wales and the March A.D. 400-700', in I. Foster and L. Alcock (eds.), Culture and environment (London, I 963 ), 299 and 301 .

${ }^{6}$ Published as N. Edwards and A. Lane (eds.), A gazetteer of early medieval settlements in Wales, A.D. $400-1100$ (Cardiff and Bangor, 1988).

${ }^{7}$ E. Campbell, 'The Post-Roman imported pottery', in Green, op. cit. in note 3, I i 7-i 8; E. Campbell, 'Longbury Bank' in Edwards and Lane, op. cit. in note 6, 88-9o.

${ }^{8}$ J. G. Evans and J. Rhys (eds.), The text of the Book of Llan Dâv (Oxford, I 893); for recent discussion of the charters see W. Davies, An early Welsh microcosm (London, 1978) and The Llandaff Charters (Aberystwyth, I979). The general validity of Davies' view is supported by P. Sims-Williams in his review of Evans and Rhys and W. Davies I 978 and I 979 in J. Ecc. Hist. 332 (1982), I 24-29 and in Religion and literature in western England, 600-80o (Cambridge, I990), 45-47. The relevant charters are discussed in detail below.

9 The problem of discovery and recognition of early medieval sites in Wales and the date of the origin of the medieval dispersed settlement pattern were both priorities identified by EMWARG; see Edwards and Lane, op. cit. in note $6,2-3$ and $10-13$.

10 For Dinas Powys imports see L. Alcock, Dinas Powys, an Iron Age, Dark Age and early medieval settlement in Glamorgan (Cardiff, I963), i25-40, reprinted as Economy, society and warfare among the Britons and Saxons (Cardiff, 1987), I I6-22; and E. Campbell, 'The post-Roman pottery', in Edwards and Lane, op. cit. in note 6, I $24-36$.

${ }^{11}$ E. Campbell, Imported goods in the early medieval Celtic West: with special reference to Dinas Poreys (unpublished Ph.D. thesis, University of Wales, College of Cardiff, r 99 I).

${ }^{12}$ Ibid., I I $1-36$.

13 To be published by the National Museum of Wales.

14 Copies are available on application to the School of History and Archaeology, UWC Cardiff.

15 Geological Survey map, No. $244 / 5$, scale I in. to I mile. 
${ }^{16}$ F. Laws, "The Old Quay House, Penally', Archaeol. Cambrensis ( 5 th ser.) 4 ( 1887 ), I 4 6-48; the inlet is shown as sea on maps of the 17 th and 18 th centuries.

17 Ibid., 146.

${ }^{18} \mathrm{H}$. Owen (ed.), The description of Penbrokshire by George Owen of Henllys, Lord of Kemcs, 3 vols. (reprinted London, I 892 ).

${ }_{19}$ 'T. James, 'Where sea meets land: the changing Carmarthenshire coastline', in H. James (ed.) Sir Gar. Studies in Carmarthenshire history (Carmarthen, I99I), I 43-66; E. Campbell, 'New finds of post-Roman imported pottery from South Wales', Archaeol. Cambrensis r 38 (rg88), 6 I.

20 Tithe Map Schedulc, Penally parish, I $84 \mathrm{I}$.

${ }^{21}$ Green, op. cit. in note 3, 103.

22 Sortie $28 / 7 / 89$; no. I $98 / \mathrm{r} 7$.

${ }^{23}$ Data from Dyfed Archaeological Trust, Sites and Monuments Record.

24 A. David, 'Report on the geophysical survey of Longbury Bank' (unpublished).

25 Holloway Farm is first recorded in 1397 , B. Howells, 'Open fields and farmsteads in Pembrokeshire', Pembrokeshire Historian 3 (197 I), 27, note 68.

26 See below on the Llandaff charter evidence and Figure $9 B$.

${ }^{27} \mathrm{~J}$. Wacher, The towns of Roman Britain (London, I 974), 393; T. James, Carmarthen: an archaeulogical and topographical survey (Carmarthen, I 980 ), I 7-18.

${ }^{28} \mathrm{~W}$. Davies, Wales in the early Middle Ages (Leicester, I982), 90

${ }^{29}$ For recent discussion see M. Lapidge and D. Dumville (eds.), Gildas: nexe approaches (Cambridge, I 984 ).

${ }^{30} \mathrm{~K}$. Jackson, Language and history in early Britain (Edinburgh, I953), I 70-76; D. S. Evans, 'Irish and the languages of post-Roman Wales', Studies 68 (1 979), 20-28.

${ }^{31}$ Davies, op. cit. in note 28 , i $6-20$, fig. 45 .

32 The excavations were carried out by the staff and students of UWC Cardiff in fine sunny weather for three weeks each in the summers of 1988 and 1989 .

33 Edwards and Lane, op. cit. in note 6, fig. 18.

${ }^{34}$ Initially the entire depth of the ploughsoil was removed by trowelling in the hope of identifying patterns of distribution which might indicate the existence of former buildings, but this proved to be unproductive. Experience showed that the early medieval finds were located in the lowest few centimetres of soil or in bedrock hollows.

${ }^{35}$ It was only after the recognition of a similar feature in the roof of the nearby Hoyle's Mouth cave that these could confidently be argued to be natural features.

${ }^{36}$ For similar problems in identifying features in this type of bedrock see P. Rahtz et al., Cadbury Congresbury $1968-73$. A late/post-Roman hilltop settlement in Somerset (Oxford, I992), I I-I 2, 30, 76 .

${ }^{37}$ For comparable profiles see Rahtz et al., ibid., fig. I 3 .

38 These included General Pitt Rivers, see Green, op. cit. in note 3 -

${ }^{39}$ Edwards and Lane, op. cit. in note 6, 4- 0.

40 C. S. Green, Excavations at Poundbury, Dorchester, Dorset I966-82 Volume I: The settlements (Dorchester, I 987), 79-82, 9I; P. Rahtz, 'Excavations on Glastonbury Tor, Somerset I964-6', Archaeol. J. I 27 ( I 970), figs. 8-10; Rahtz et al., op. cit. in note 36 , Structure I, figs. I $37-38$, 193 .

${ }_{41} \mathrm{~A}$ putative palisade noted in the $\mathrm{I} 988$ interim report and possible post-hole were later recognized as a natural fissure and vertical solution pipe.

${ }^{42}$ But note the religious interpretation of two similar isolated 'post-holes' at Cadbury Congresbury, Rahtz et al., op. cit. in note $36,36-37,65$.

${ }^{43} \mathrm{G}$. Rolleston et al., 'Report of a committee ... appointed for the purpose of examining two caves containing human remains, in the neighbourhood of Tenby', Rep. Brit. Assoc. Advancement Sci. (1878), 2 I4.

${ }^{44}$ Green, op. cit. in note 3, I03

45 Ibid., I 06.

46 L. Alcock, 'Cadbury-Camelot: a fifteen-year perspective', Proc. Brit. Acad. 68 ( 1982 ), 370-74.

${ }^{47}$ D. Crowther, 'Old land surfaces and modern ploughsoils: implications of recent work at Maxey', Scot. Archaeol. Rev. 2 ( $\mathrm{Ig}_{3}$ ), $3 \mathrm{I}-44$.

${ }^{48}$ Campbell, op. cit. in note i i, illus. 125.

$49 \mathrm{D}$. F. Thornton of the Department of Medieval and Later Antiquities of the British Museum provided the following opinion (in litt.). 'It is definitely not thought to be Roman or early medieval but there is considerable uncertainty as to where it might be placed within the medieval and later period. We thought initially that it might be of Renaissance or 17 th-century date in view of some box-link chains from shipwrecks which we have recently examined at Christie's but the chains in question were larger in scale and considerably heavier. This raised the question that the chain may in fact be of the Igth century, but we do not have any comparable examples of igth-century date in our collection. It is the light weight and fineness of the chain which seem to place it in the I $9^{\text {th }}$ century'.

50 R. Brucc-Mitford, The Sutton Hoo ship-burial, vol. 3 (London, 1983), I-19 I

51 Ibid., I 7o, Table I, bowl Inv. 86 is particularly close; comments on analysis in litt. M. Hughes, BM Laboratory.

52 R. F. Tylecote, The prehistory of metallurgy in the British Isles (London, I 986), 76-77, Table 46.

53 T. Dickinson, 'Fowler's Type G penannular brooches reconsidered', Medieval Archaeol. 26 ( ${ }^{2} 982$ ), 4I-68.

54 Ibid., 44-46; J. Graham-Campbell, Archaeol. J. I 33 (1976), 277-89.

55 E. Campbell and A. Lane 'Celtic and Germanic interaction in Scottish Dalriada: the 7 th-century metalworking site at Dunadd', in J. Higgitt and M. Spearman (cds.), The age of migrating ideas (Edinburgh, I 993), 52-63; S. Youngs (ed.), "The work of angels': masterpieces of Celtic metalwork, 6th-gth centuries A.D. (London, i989), nos. 164 and I80. 
${ }^{56}$ For the zoomorphics see H. Kilbride-Jones, Zoomorphic penannular brooches (London, 980 ); for illustration of the Pant-y-Saer brooch, M. Redknap, The Christian Celts: treasures of Late Celtic Wales (Cardiff, r 99I), $3 \mathrm{I}$

57 Newport Museum, unpublished.

${ }^{58}$ Redknap, op. cit. in note $56,3^{2}$ top left; 32 bottom left, NMW Acc. No. I 1.52.

${ }^{59} \mathrm{E}$ ware: NMW Acc. No. 30.1 52/2, probably from the site at SR 896976 described by A. L. Leach, 'Stone implements from soil-drifts and chipping floors in S. Pembrokeshire', Archaeol. Cambrensis (I9I 3), 39I-432, fig. 4, Site $\mathrm{D}_{4}$. Comb: NMW Acc. No. I I.5 I, unpublished, but probably from the site at SR 898974 described in Pringle, 'Note un a shell mound on Linney Burrows, near Pembroke', Archaeol. Cambrensis ( 19 ro), $3^{\mathrm{I}} 3^{-\mathrm{I}} 4$.

60 Leach, ibid., fig. I 3.

61 Graham-Campbell, op. cit. in note 54, 279

62 See note 5.5 .

63 Unpublished excavation by P. Gelling; material in Isle of Man Museum, Douglas, find no. I 974/1.

${ }^{64}$ Campbell, op. cit. in note I I, 3 I 4 .

$65 \mathrm{X}$. Whitfield, 'Motifs and techniques of Celtic filigree: are they original?' in M. Ryan (ed.) Ireland and Insular Art A.D. 500-1200 (Dublin, I 987 ), 75-84; Youngs, op. cit. in note 55, 2 I .

66 M. Redknap, 'Newton Moor', Archaeol. Wales 31 ( 1991$), 42-43$, and 38 fig. I (wrongly captioned as from Llangorse).

67 Archaeol. Wales 26 ( 1986 ), 58.

${ }^{68} \mathrm{~J}$. Graham-Campbell, 'Dinas Powys metalwork and the dating of enamelled zoomorphic penannular brooches', Bull. Board Celtic Stud. 38 (1991), 220-32.

69 Ibid.

70 Thanks to B. Trett, Newport Museum for allowing me access to this brooch.

${ }^{71}$ Examples from Lydney, R. E. M. Wheeler and T. V. Wheeler, Excavation of the prehistoric, Roman and post-Roman site in Lydney Park, Gloucester (London, I933), fig. I $7 \mathrm{~s}$; Colchester, N. Crummy, The Roman small-finds from excavations in Colchester 197I-9 (Colchester, I983), figs. $4 \mathrm{I}-47$.

72 Campbell, op. cit. in note I I, illus. 80; Tintagel, ibid., 319.

73 Alcock i 963 , op. cit. in note ro, ro4-12.

${ }^{74}$ Cf. Graham-Campbell, op. cit. in note 68.

75 A.A.S. analyses carried out by R. Jones, Department of Archaeology, UWC Cardiff, Microprobe analyses by P. Northover, Dept. of Materials, University of Oxford, using CAMEBAX automated instrument.

${ }^{76}$ Campbell and Lane, op. cit. in note 55; M. Redknap and B. Trett pers. comm.

${ }^{77}$ C. Mortimer, 'Anglo-Saxon copper alloys from Lechlade, Gloucestershire', Oxford J. Archaeol. 7 (I 988), 227-33; 'A descriptive classification of early Anglo-Saxon copper-alloy compositions: towards a general typology of early medieval copper alloys', Medieval Archaeol. 35 (I 99 I), I04-07, fig. r.

${ }_{78}$ These are identical to Cadbury Congresbury Type E, Rahtz, op. cit. in note 36 , fig. 89 .

${ }^{79}$ Alcock, op. cit. in note Io; P. Hill, Whithorn 3 (Whithorn, I990) and Whithorn 4 (Whithorn, I992), and report on imports by E. Campbell, forthcoming.

${ }^{80}$ Campbell, op. cit. in note I I, summarized in 'The archaeological evidence for contacts: imports, trade and economy in Celtic Britain A.D. 400-800', in Dark, K. R. (ed.), External contacts and the economy of Celtic Britain A.D. 400-800 (Woodbridge, forthcoming). For other recent general accounts see M. Fulford, 'Byzantium and Britain: a Mediterranean perspective', Medieval Archaeol. 33 (I989), I-6; C. Thomas, 'Gallici nautae de Galliarum provincii': a 6 th- to 7 th-century trade with Gaul reconsidered', Medieval Archaeol. 34 (1990), I-26.

81 Fabrics are described in archive.

${ }^{82} \mathrm{~J}$. Hayes, Late Roman pottery (London, I972); F. Mayet and M. Picon, 'Une sigillée phocéenne tardive (Late Roman C) et sa diffusion en Occident', Figlina 7 ( 1986 ), i $29-42$.

${ }_{83}$ A. L. Leach, 'Nanna's Cave, Isle of Caldey', Archaeol. Cambrensis (1916), I 78.

${ }^{84}$ Hayes, op. cit. in note 82, 357; the animal stamp would belong to the same period as the well-known Dinas Powys dish, Alcock i 963 , op. cit. in note ro, fig. 25.

${ }^{85}$ Campbell, op cit. in note $1,27-28$.

86 Work is in progress at the Dept. of Archacological Science, Bradford University, under the direction of Dr Carl Heron, of residues from amphorae sherds from Tintagel. Analysis of $L B_{11} 85$, which has a black deposit on the interior, showed negative results.

${ }^{87}$ Campbell, op. cit. in note I $1,184-89$; cf. Fulford, op. cit. in note 80.

${ }^{88} \mathrm{~S}$. Keay, Late Roman amphorae in the western Mediterranean (Oxford, British Archaeol. Reports 5, I984), $402-05$. 89 Campbell, op. cit. in note 79 .

$90 \mathrm{~J}$. Rigoir, 'Les sigillées paléochretiénnes grise et orange', Gallia 26 ( I 968), i 77-244; J. Rigoir et al., 'Les dérivées paléochrétiennes du groupe atlantique', Gallia 3 I (I973), 207-64; Campbell, op. cit. in note I I, 29-30.

${ }^{91}$ Campbell, in Edwards and Lane, op. cit. in note 6, fig. 30, nos. $44,45,49$.

92 Kindly shown to me by Cathy O'Mahoney; Campbell, op. cit. in note I I, illus. 39, E I 5 .

${ }^{93}$ Identified by S. Greep, Verulamium Museum.

${ }^{94} \mathrm{Cf}$. Alcock i 963 , op. cit. in note 10 , fig. 40 , i i 9 .

${ }^{95}$ For this glass in general see D. B. Harden, 'Glass vessels in Britain and Ireland A.D. 400-r ooo', in D. B. Harden (ed.) Dark Age Britain (London, I 956), I 32-56; Campbell, op. cit. in note i I, 4I-49. For Dinas Powys D. B. Harden, "The glass', in Alcock, I963, op. cit. in note 10, 178-88; E. Campbell, 'A blue glass squat jar from Dinas Powys, South Walcs', Bull. Board of Celtic Stud. 36 (1989), 239-45. For Mote of Mark, Harden 1956. loc. cit., also recent material in possession of D. Longley. Cadbury Congresbury, Rahtz, op. cit. in note 36 . Whithorn, Hill, op. cit. in note 79 . 
96 Campbell, op. cit. in note i I, i 98 . Recent work on the Whithorn assemblage confirms that imported glass was available throughout the 6 th and 7 th centuries, with the main concentration in the later 6 th and early 7 th centuries.

${ }^{97}$ Campbell I 989 , op. cit. in note 95 .

98 Campbcll, op. cit. in note $\mathrm{I}$, table $2 \mathrm{I}$.

$99 \mathrm{~J}$. Y pey, 'Die Funde aus dem frühmittelalterlichen Gräberfeld Huinerveld bei Putten im Museum Nairac in Barneveld', Berichten van de Rijkdienst voor het Oudheidkundig Bodemonderzoek I 2-I 3 (1962-63), I 44-47, abb. 40. But note Henderson's comments on the analyses of these sherds.

100 J. Hunter, 'The glass', in P. Holdsworth, Excavations at Melbourne St., Southampton 197I-6 (London, 1980), 68-69. It should be noted that vessels with similar basal spirals are found at Whithorn Priory in 7 th-century contexts, see note 79 .

101 Harden 1956 , op. cit. in note 95 , fig. 25 ; Campbell 1989 , op. cit. in note 95 .

102 Department of Archacology and Prehistory, University of Sheffield, Sheffield S ro 2 TN.

$103 \mathrm{~J}$. Henderson. 'Electron probe microanalysis of mixed-alkali glasses', Archaeometry 30. I ( $\mathrm{I} 988$ ), 77-9 I.

104 W. E. S. Turner and H. P. Rooksby, 'Further historical studies based on X-ray diffraction methods of the reagents employed in making opal and opaque glasses', Jahrbuch des Römisch-Germanischen Zentralmuseums Mainz 8 ( $196 \mathrm{I}), \mathrm{I}-6$.

$105 \mathrm{~J}$. Henderson, 'The raw materials of early glass production', Oxford J. Archaeol. 4.3 (I 985), $267-9 \mathrm{I}$.

106 I. Freestone, 'Looking into glass', in S. Bowman (ed.), Science in the past (London, I99 I), 47-50.

107 M. Bimson, 'Coloured glass and millefiori in the Sutton Hoo grave deposit', in A. Care Evans (ed.), The Sutton Hoo ship-burial, Vol. 3 (London, 1983), 935-36, 944.

$108 \mathrm{~J}$. Henderson. 'Electron-microprobe investigation of Early Irish glass and glass-making practices', Materials Issues in Art and Archaeology I, Materials Research Society Symposium Proceedings I 23 ( 1988 ), I 4 I-46; J. Henderson, 'The nature of the Early Christian glass industry in Ireland: some evidence from Dunmisk fort, Co. Tyrone', Ulster J. Archaeol. $5^{\text {I }}$ ( 1988 ), I I 5-26.

${ }_{109}$ J. Calmer and J. Henderson, 'Glassworking at Åhus, S. Sweden (eighth century A.D.)', Laborativ Arkeologi 5 ( I 991), Arkeologiska Forskningslaboratoriet Stockholms Universitet, I 43-54; J. Callmer, J. Henderson and U. Näsman, The glass and glass technology at Ahus and Ribe, in preparation.

${ }^{110} \mathrm{~J}$. Henderson, 'Analysis of some opaque glass from Hamwic', in Excavations in Southampton, forthcoming.

111 J. G. Hurst, 'Middle-Saxon pottery', Medieval Archaeol. 3 (1959), 13-31. Roman loomweights are usually pyramidal, see J.P. Wild, Textile manufacture in the northern Roman provinces (Cambridge, 1970), 63

112 Alcock, I963, op. cit. in note 10, fig. 33, 3; D. Robinson, Biglis, Llandough and Caldicot (Oxford, British Archaeol. Reports Brit. Ser. I 88, i 988), fig. 26; M. Hassall and J. Rhodes, 'Excavations at the New Market Hall, Gloucester, ig66-7', Trans. Bristol Glouc. Archaeol. Soc. 93 (1974), fig. 34, i 2; H. Mytum pers. comm.

113 The published drawing is misleading at it does not show the section.

114 Alcock I 963, op. cit. in note 1o, fig. 30 .

115 J. Bayley, 'Archaeological evidence for parting' in E. Pernicka and G. A. Wagner (eds.), Archaeometry 'go (Basel, 199 I), I $9-28$.

116 A. L. Leach, 'An implement of crystalline quartz from Freshwater West, Pembrokeshire', Archaeol. Cambrensis (I9I I) , 78-80.

117 Veins of iron ore do occur in the limestone I $\mathrm{km} \mathrm{S}$. of the site: Geological Survey Map I in. to I mile, No. 244/5. 118 P. Crew pers. comm.

119 Calibration according to M. Stuiver and G. W. Pearson, 'High precision calibration of the radiocarbon timescale, A.D. 1 950-500 B.C.', Radiocarbon 28 (1986), 805-38.

${ }_{120}$ Full details can be found in the archive.

121 Identified by L. Zienkiewicz, UWC Cardiff

122 Details in archive.

123 A Dark Age date is not impossible as it is similar in size and form to the Structure II 'shrine' at Cadbury Congresbury, Rahtz etal., op. cit. in note 36 , r 97 , fig. 139 .

124 Howells, op. cit. in note 25,25 , note 43 .

125 Tithe Map Schedule, I 84 I.

126 B. G. Charles, The non-Celtic place-names of Wales (London, 1938), 298, records one other example of the use of Back as a field name in Pembrokeshire.

127 Ibid., 290.

128 Ibid., 290: Lamborough and Sentence Camp.

129 Ibid., 289.

130 Davies 1978 , op. cit. in note $8, \mathrm{I} 35$.

131 The charter numbers refer to the page numbers of Evans and Rhys, i 893, op. cit. in note 8.

132 Davies i 979 , op. cit. in note 8,96 , no. 125 b.

133 Ibid., 96-97, no 127 a

134 Ibid., I 26 , no. 253.

135 Ibid., 95 , no. I 23 .

136 There appears to be no documentary evidence for the name of this river before the mid I 9 th century, and it is possible that it was renamed at that time out of antiquarian interest in the Llandaff charter evidence, in the belief that this was the Ritec of the charters. However, even it this was so, the assumption must be justified as there is no other substantial river 'near Penally', not to mention the evidence localizing certain of the charters given here.

${ }^{137}$ Castle Gwynne in Tithe Map Schedule r 84 I. 
138 R.C.A.H.M.W., Inventory of the momuments of Pembrokeshire (Cardiff, I 925), 291 . Castle Gwynne is not a common field name in this area, and this is the only example of this or any similar name in the Lordship of Penally rccorded in the 'Tithc Map Apportionment.

139 Evans and Rhys, op. cit. in note 8, 253. For Teilo sce D. S. Evans (ed.), Lives of the Welsh saints by G. H. Doble (Cardiff, 1971), 162-206.

${ }_{140}$ La Torre 1324 i.p.m.; Charles, op. cit. in note 126, 22. Note there arc two Tarrs, East or Great Tarr and West Tarr.

141 Torre and Carswelle $1326-27$ Min. Acc. I208 no. 5 mi2; Torre and Carswill 1348 i.p.m. Ed. III no. 18.

142 It is so located on W. Rees, Map of south Wales in the XIVth century (Cardiff, I933), though the basis for this is unknown and his attributions can be unreliable.

143 'Stream of the lepers' in Welsh.

${ }^{144}$ Evans and Rhys, op. cit. in note 8, 254-55.

145 If this was the case the place-name would be purely topographical, and would indicate that there was no memory of its occupation, certainly by the I 2 th century.

${ }_{146}$ Menechi can be translated as 'of the monks', presumably referring to its possession by the monks of Penally.

${ }_{147}$ Penholway 1841 ; Penhallow alias Pullalloch I6 8 ; Penhollow i6og. See note 15 I for sources.

148 In fact, charter i 27 a has a preamble which incidentally mentions 'the pigs of a man of Penally' causing damage at Ciltutuc and Penclecir, which shows both that pigs were kept in this area and that they could roam freely along the scrubland of the Ridgeway (see Figure gB).

${ }_{149}$ Davies 1978 , op. cit. in note 8,33 .

150 Sims-Williams has argued (pers.comm.) that all of the bounds in Welsh were written at the time of compilation of Liber Landavensis; Davies 1979 , op. cit. in note 8 points out the difficulties of this view.

${ }_{151}$ P.R.O. LR2/206, ff. $4^{2-1}$ 7 7 : estate extents 1609 and 1618 , National Library Wales, Picton Collection, MS. Maps of estates of Sir Richard Phillips Bart. I 773. Although the field pattern has traces of what appears to be a very large enclosure around Penally, such as those found on other early Irish and Welsh ecclesiastic sites, this seems to be a boundary deriving from topographical/environmental zones.

152 Davies 1978 , op. cit. in note 8, 39-40.

153 One of these farms, Carswell, has a succession of farmhouses still extant, dating to the I 4th, 16 th, I 9 th and 20 th centuries, all sited progressively upslope; RCAHMW, op. cit. in note 138, 29I; CADW excavation results, pers. comm. S. Phillips.

${ }_{154}$ V. E. Nash-Williams, The Early Christian monuments of Wales (Cardiff, I950), nos. 363-66; a clas church according to W. Rees, Historical atlas of Wales (Cardiff, 1959), pl. 27; but see H. Pryce, 'Pastoral care in early medieval Wales', in J. Blair and R. Sharpe (eds.), Pastoral care before the parish (Leicester, I 992), 4I-62 for a discussion of the organization of the Welsh pre-Conquest church.

$155 \mathrm{C}$. Knowles and R. Neville Hadcock, Medieval religious houses: England and Wales (London, i 953), 357.

156 Howells, op. cit, in note 25,21 .

157 Around St Florence, Tenby and Penally towns the fields are small and S-shaped, betraying their origin in township quillets, while elsewhere there are long rectangular strips of fields which are obviously the planned enclosures of the Manorbier estate.

158 Davies 1979 , op. cit. in note $8,2$.

159 Evans, loc. cit. in note I 39 .

160 I. Williams, 'Moliant Dynbych Penfro', Trans. Hon. Soc. Cymmrodorion (1940), 66-83.

161 Campbell, op. cit. in note II, I0I-03; the Late Roman sites are Whitton, Caldicot, Biglis and Cae Summerhouse; the early medieval are Dinas Powys, Coygan Camp, Drim and Glan-y-Mor.

162 Ibid., $103-05$.

163 Data from Dinas. Powys from Campbell, op. cit. in note I I, illus. I04.

$164 \mathrm{See}$ for instance U. Sommer, 'Dirt theory, or archaeological sites seen as rubbish heaps', J. Theoretical Archaeol. I ( 1990$), 47-60$. See also the discussion of glass distribution at Cadbury Congresbury, Rahtz, op. cit. in note $3^{6}$,

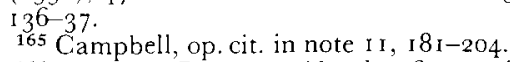

${ }^{166}$ For Dinas Powys see Alcock I 963 , op. cit. in note I0, 54-55; for South Cadbury see Alcock, op. cit, in note 46; for Cadbury Congresbury see Rahtz, op. cit. in note $3^{6}, 249^{-} 5^{\circ}$.

${ }^{167}$ See for instance C. Mortimer, op, cit. in note 77 .

168 Tin was being mined in Cornwall at this period, see R. Penhallurick, Tin in aniquity (London, I 986), 2 I $2,234$.

$169 \mathrm{M}$. Nieke and H. Duncan, 'Dalriada: the establishment and maintenance of an early historic kingdom in northern Britain', in S. Driscoll and M. Nieke (eds.), Power and politics in early medieval Britain (Edinburgh, 1988), $6-2 \mathrm{I}$.

${ }_{170}$ Campbell, op. cit. in note I I, I 52-54, tables $5-8$.

${ }^{171}$ E.g. T. Fanning, 'Excavation of an early Christian cemetery and settlement at Reask, County Kerry', Proc. Royal Irish Acad. $8 \mathrm{IC}$ ( $198 \mathrm{I}), 3^{-1} 72$. There is also now a large quantity of material from the Whithorn Priory site, sec note

79.72 H. S. Green, pers, comm.

173 These are shown on the section drawn by Rolleston preserved in Tenby Museum. See Green, op. cit. in note 3 , I O I, fig. 29.

174 The dates range from $4600-4900$ B.P., see Phasing and Chronology.

175 For Caldey see Campbell, op. cit. in note 19.

${ }^{176}$ R. Hodges, Dark Age economics (London, i 989 , 2nd ed.), 56-69. 
177 For a similar assessment of Cadbury Congresbury see Rahtz, op. cit. in note $3^{6}, 23^{8-50}$.

${ }_{178}$ Campbell, op. cit. in note 11,146 , I 75 .

179 Campbell, op. cit. in note i 9.

${ }^{180}$ See Settlement History.

181 A. Milles, The molluscan biostratigraphy and archaeology of Holocene coastal blown sand in the British Isles (unpublished Ph.D. thesis, Lniversity of Wales, College of Cardiff, I 990 ).

182 For site see Edwards and Lane, op. cit. in note 6, 85; for metalwork Redknap, op. cit. in note 56,32 .

${ }^{183}$ Edwards and Lane, op. cit. in note 6, I I 7.

184 Campbell, op. cit. in note i i, illus. 201.

185 The following discussion is based on the work of onc of us, Campbell, op. cit. in note I I.

186 C. Thomas, Gwithian: ten years' work 1949-1958 (Gwithian, 1958).

187 Thomas, op. cit. in note $80, \mathrm{I} 6$.

188 I. Crawford and R. Switsur, 'Sandscaping and C I 4: the Udal, N. Uist', Antiquity 5I (1977), 124-36; A. Ritchie, 'Excavation of Pictish and Viking-age farmsteads at Buckquoy, Orkney', Proc. Soc. Antiq. Scot. 108 ( I977), $174-227$.

189 Alcock 1987 , op. cit. in note $10,16 \mathrm{I}-63,2 \mathrm{I} \mathrm{I}-13$.

190 Data from Dyfed Archaeological Trust Sites and Monuments Record, with additions by the author.

${ }^{191}$ Carew Castle: 'Medieval Britain and Ireland in I989', Medieval Archaeol. 34 (1990), 249. Caldey: Campbell, op. cit. in note I9. Coygan Camp: G. Wainwright, Coygan Camp (Cardiff, I 966).

192 Comb: Pringle, op. cit. in note 59. Brooch: Redknap, op. cit. in note 56,32 bottom left. Pins and necklace: A. G. O. Mathias, 'South Pembrokeshire early settlements', Archaeol. Cambrensis 82 (1927), i 88-95, figs. 3, 4. E ware: Figure 6, A, see note 59 .

${ }_{193}$ H. James, 'Excavations at Caer Bayvil 1979', Archaeol. Cambrensis I 36 (1987), $5^{1-76}$.

194 Williams, op. cit. in note 160 .

195 Edwards and Lane, op. cit. in note 6, 74 .

196 Vash-Williams, op. cit. in note 154 .

197 K. R. Dark and H. Mytum (pers. comm.).

198 Campbell, op. cit. in note i i, i i 2.

199 Buliber Camp: Dyfed Archaeological Trust SMR: 550 records wheel-made pottery from the site.

200 Campbell, op. cit. in note $\mathrm{I}$, table 6. Cannington cemetery is an exception, though the amount of imported material is small.

${ }^{201} \mathrm{~J}$. L. Davies, Aspects of native settlement in Roman Wales and the Marches (unpublished Ph.D. thesis, University College Cardiff, Liniversity of Wales, i 980$), 487$.

202 C. O'Mahoney, pers. comm.

203 E. Laws, The history of Little England beyond Wales and the non-Kymric colony settled in Pembrokeshire (London, I 888), 46.

204 Ibid., 44-47; R. E. M. Wheeler, 'A Roman site in Pembrokeshire', Archaeol. Cembrensis 78 ( I 923 ), 2 I I-24.

205 H. N. Savory, 'Excavations at the Hoyle, Tenby, in I 968', Archaeol. Cambrensis I 22 (1973), 27; Anon. CambrianJ. ( 1862 ), 95 .

206 Edwards and Lane, op. cit. in note 6, 74

207 See note 199

208 Campbell, op. cit. in note II, 56-58; 'Hen Gastell', Archaeol. in Wales 31 (1991), 43.

209 Campbell, op. cit. in note I I, I I I-26.

${ }^{210}$ Edwards and Lane, op. cit. in note 6, 68-69, 79, I I9-20.

211 Degannwy: Edwards and Lane, op. cit. in note 6, 52. Viking raids in Dyfed: Davies, op. cit. in note 28 , I 16.

${ }^{212}$ W. Davies, 'Roman settlements and post-Roman estates in south-east Wales', in J. Casey (ed.), The end of Roman Britain (Oxford, British Archaeol. Reports Brit. Ser. 7 I, I979), 156-60; C. Thomas, 'The end of the Roman south-west', in K. Branigan and P.J. Fowler (eds.), The Roman West Country (Newton Abbot, I976), 209. 